\title{
Diversidade florística de Rubiaceae na Serra da Fumaça - complexo de Serras da Jacobina, Bahia, Brasil*
}

\author{
Luzicléia Araújo Sousa ${ }^{1,3}$, Hortensia Pousada Bautista ${ }^{1}$ \& Jomar Gomes Jardim ${ }^{1,2}$ \\ ${ }^{1}$ Programa de Pós-graduação em Biodiversidade Vegetal, Departamento de Educação, \\ Universidade do Estado da Bahia - UNEB, Rua do Gangorra, 503, CEP 48608-240, \\ Paulo Afonso, BA, Brasil. http://www.uneb.br/ppgbveg \\ ${ }^{2}$ Departamento Botanica, Ecologia e Zoologia, Centro de Biociências, Universidade Federal do Rio \\ Grande do Norte-UFRN, CEP 59072-970, Natal, RN, Brasil. http://www.cb.ufrn.br/dbez/dbez.htm \\ ${ }^{3}$ Autor para correspondência: Luzicléia Araújo Sousa,e-mail: luzicleiaraujo122@gmail.com
}

*Parte da dissertação da primeira autora.

SOUSA, L.A., BAUTISTA, H.P. \& JARDIM, J.G. Floristic diversity of Rubiaceae on the Serra da Fumaça - Mountains complex of Jacobina, Bahia, Brazil. Biota Neotrop. 13(3): http://www.biotaneotropica. org.br/v13n3/en/abstract?inventory+bn02313032013

\begin{abstract}
This paper is a survey of Rubiaceae species found in the Serra da Fumaça - Mountains Complex of Jacobina, Bahia. In the period of Juny/2011 until August/2012 were taken monthly from botanical material along trails and in the forest contemplating all vegetation types in the area. We recorded 36 species in 20 genera. The most representative in number of species were Borreria G.Mey. (5 spp.), Diodella Small, Mitracarpus Zucc. ex Schult. \& Schult.f. and Psychotria L. (3 spp. each), followed by Coccocypselum P.Browne, Declieuxia Kunth, Palicourea Aubl., Perama Aubl., Richardia L. and Staelia Cham. \& Schltdl. (2 spp. each). The other genera were represented only by one species: Cordiera elliptica (Cham.) Kuntze, Coutarea hexandra (Jacq.) K.Schum., Emmeorhiza umbellata (Spreng.) K.Schum., Genipa americana L. Guettarda sericea Müll.Arg., Malanea macrophylla Bartl. ex Griseb., Manettia cordifolia Mart., Posoqueria latifolia (Rudge) Roem. \& Schult., Sabicea grisea Cham. \& Schltdl. and Tocoyena formosa (Cham. \& Schltdl.) K.Schum.). Two endemic species were recorded, one of the Chapada Diamantina (Perama harleyi J.H.Kirkbr. \& Steyerm.) and one of caatinga (Guettarda sericea Müll Arg.). Psychotria jambosioides Schltdl. and P. mapourioides DC. were recorded for the first time to the Espinhaço Range, both known only from the Atlantic coast. Identification key to the species, descriptions, illustrations and information on the geographical distribution of species and phenological data are displayed.
\end{abstract}

Keywords: taxonomy, caatinga, campo rupestre, seasonal forest, Chapada Diamantina.

SOUSA, L.A., BAUTISTA, H.P. \& JARDIM, J.G. Diversidade florística de Rubiaceae na Serra da Fumaça - complexo de Serras da Jacobina, Bahia, Brasil. Biota Neotrop. 13(3): http://www.biotaneotropica. org.br/v13n3/pt/abstract?inventory+bn02313032013

Resumo: Este trabalho consiste no levantamento das espécies de Rubiaceae encontradas na Serra da Fumaça - complexo de Serras da Jacobina, Bahia. No período de junho de 2011 a agosto de 2012 foram realizadas coletas mensais de material botânico ao longo de trilhas e no interior da floresta contemplando todas as fitofisionomias existentes na área. Foram registradas 36 espécies distribuídas em 20 gêneros. Os gêneros mais representativos em número de espécies foram Borreria G.Mey. (5 spp.), Diodella Small, Mitracarpus Zucc. ex Schult. \& Schult.f. e Psychotria L. (3 spp. cada), seguidas por Coccocypselum P.Browne, Declieuxia Kunth, Palicourea Aubl., Perama Aubl., Richardia L. e Staelia Cham. \& Schltdl. (2 spp. cada). Os demais gêneros foram representandos por apenas uma espécie cada: Cordiera elliptica (Cham.) Kuntze, Coutarea hexandra (Jacq.) K.Schum., Emmeorhiza umbellata (Spreng.) K.Schum., Genipa americana L., Guettarda sericea Müll. Arg., Malanea macrophylla Bartl. ex Griseb., Manettia cordifolia Mart., Posoqueria latifolia (Rudge) Roem. \& Schult., Sabicea grisea Cham. \& Schltdl., Tocoyena formosa (Cham. \& Schltdl.) K.Schum. Foram registradas duas espécies endêmicas, uma da Chapada Diamantina (Perama harleyi J.H.Kirkbr. \& Steyerm.) e outra da caatinga (Guettarda sericea Müll.Arg.). Psychotria jambosioides Schltdl. e P. mapourioides DC. foram registradas pela primeira vez para a Cadeia do Espinhaço, ambas conhecidas apenas da Mata Atlântica litorânea. Chave de identificação para as espécies, descrições, ilustrações e informações sobre a distribuição geográfica das espécies e dados fenológicos são apresentados.

Palavras-chave: taxonomia, caatinga, campo rupestre, floresta estacional, Chapada Diamantina. 


\section{Introdução}

Rubiaceae inclui 620 gêneros e 13.200 espécies (Govaerts et al. 2012), apresenta distribuição cosmopolita sendo mais diversa na região tropical (Andersson 1992, Maldonado 2005, Delprete \& Jardim 2012). Para a região Neotropical são citadas 5.000 espécies em 217 gêneros (Delprete et al. 2004).

No Brasil, a família é significativamente diversa sendo a quinta maior entre as angiospermas com 1.380 espécies em 119 gêneros com representantes em todos os domínios fitogeográficos (Barbosa et al. 2012). Tratamentos florísticos para a família têm sido realizados em várias regiões do Brasil, sendo os pioneiros e mais completos aqueles publicados na Flora Brasiliensis por Müller (1881) e Schumann (1888). Trabalhos mais recentes incluem revisões de alguns gêneros (ie.: Prado 1987, dados não publicados, Macias 1988, dados não publicados, Germano Filho 1999, Souza et al. 2010), e floras regionais (ie.: Costa \& Mamede 2002, Zappi et al. 2003, Delprete et al. 2004, 2005, Campos et al. 2006, Delprete \& Cortés-B. 2006, JungMendaçolli 2007, Taylor et al. 2007, Delprete 2010a, b, c).

$\mathrm{Na}$ região Nordeste do Brasil, destacam-se os trabalhos sobre floras regionais, alguns destes somando a descrição de novas espécies (ie.: Zappi \& Stannard 1995, Zappi 1998, Barbosa \& Zappi 2002, Zappi et al. 2003, Souza \& Sales 2004, Pereira \& Barbosa 2004, 2006, Melo \& Barbosa 2007, Jardim \& Zappi 2008a, b, c, Cabral et al. 2011). A família é bem representada na região com 391 espécies que incluem 76 gêneros. $\mathrm{O}$ estado da Bahia é o segundo mais diverso da família no país com 318 espécies e 67 gêneros (Barbosa et al. 2012).

A Chapada Diamantina representa a porção baiana dentro do complexo de vegetação da Cadeia do Espinhaço e apresenta alta diversidade de espécies (Harley 1995, Zappi 2008). Essas áreas encontram-se divididas em várias serras, entre elas, as Serras da Jacobina que integram a borda oriental da Chapada Diamantina (Giulietti et al. 1997). Além da riqueza de espécies, as florestas dessas regiões variam consideravelmente em composição e estrutura, como resposta às condições geo-climáticas, muitas vezes resultando em uma grande heterogeneidade de fitofisionomias em áreas florestais relativamente pequenas (ie.: Giulietti \& Pirani 1988, Harley 1995, Zappi et al. 2003, Zappi 2008).

Com base no exposto acima, o presente estudo teve como objetivos investigar a diversidade florística das Rubiaceae na Serra da Fumaça, contribuir para o conhecimento da flora local e regional, bem como, subsidiar estudos com a família e auxiliar futuras ações para a conservação da área.

\section{Material e Métodos}

\section{1. Área de estudo}

A Serra da Fumaça corresponde a uma das Serras da Jacobina (Figura 1), a qual integra a porção Norte da Chapada Diamantina (Giulietti et al. 1997). Está situada na Ecorregião da Depressão Sertaneja Meridional do bioma Caatinga, localizado no município de Pindobaçu, Bahia, sendo delimitada pelas coordenadas $10^{\circ} 38^{\prime}$ 54 " a $10^{\circ} 40^{\prime} 08^{\prime \prime} \mathrm{S}$ e $40^{\circ} 19^{\prime} 42^{\prime \prime}$ a $40^{\circ} 22^{\prime} 46^{\prime \prime} \mathrm{W}$, entre 400 e $1050 \mathrm{~m}$ de altitude (Companhia... 2005). As Serras da Jacobina estendem-se por $200 \mathrm{Km}$ no sentido norte e sul, com 15-25 km de largura e altitude de até $1.300 \mathrm{~m}$, na porção norte do estado da Bahia (Milesi et al. 2002, Mascarenhas et al. 1998). É uma das áreas identificada pelo projeto de Conservação e Utilização da Diversidade Biológica Brasileira (PROBIO), como de importância biológica extremamente alta (Giulietti et al. 2006). A vegetação do município foi caracterizada como de contato Cerrado-Floresta Estacional e CerradoCaatinga (Companhia... 2005). Apresenta clima úmido a subúmido, com temperatura média anual de $24{ }^{\circ} \mathrm{C}$ e índices pluviométricos acima de 477,6 mm/ano, com dois períodos chuvosos distintos de outubro a abril (Vale 2005). As serras da Jacobina são constituídas principalmente por filitos, xistos e quartzitos, havendo ocorrência de minérios como esmeralda e ouro (Santana et al. 1995). Os solos no município de Pindobaçu são compostos por latossolos distróficos, argilossolos distróficos ou eutróficos e neossolos litólicos distróficos. O relevo mais proeminente é o serrano, cortado pelos rios ItapicuruAçu, Aipim e Capivara e seus riachos tributários (Companhia... 2005).

\section{Coleta dos dados}

A coleta dos dados ocorreu através de expedições mensais à área de estudo, no período de junho de 2011 a agosto 2012. As coletas e observação do material botânico foram efetuadas ao longo de trilhas e no interior da floresta contemplando todas as fitofisionomias existentes na área, explorando-se ao máximo as áreas com fitofisionomias distintas. Adicionalmente, foram realizados registros fotográficos, anotações de dados dos ambientes e hábitats, e flores/frutos foram conservados em álcool a 70\% para análise posterior. Os espécimes resultantes das coletas foram processados seguindo técnicas usuais como as descritas por Mori et al. (1989). As exsicatas foram incorporadas ao acervo do (HUNEB coleção Senhor do Bonfim), e duplicatas foram enviadas por ordem de prioridade, aos herbários HUNEB - Paulo Afonso, HRB, RB e UFRN.

As identificações foram realizadas com auxílio de chaves analíticas e consulta à literatura especializada (ie.: Prado 1987, dados não publicados, Macias 1988, dados não publicados, Zappi \& Stannard 1995, Costa \& Mamede 2002, Souza \& Sales 2004, Delprete 2010a, b, c, Jung-Mendaçolli 2007, Taylor et al. 2007, Souza et al. 2010, Delprete \& Cortés-B. 2006, Cabral et al. 2011), ou por comparação com espécimes previamente identificadas por especialistas nos acervos dos herbários ALCB, BAH, CEPEC, HRB, HUEFS e HUNEB (acrônimos de acordo com Thiers 2012). Dados sobre a distribuição geográfica e fenofases das espécies foram obtidos com base na literatura e nas etiquetas dos espécimes analisados. Os nomes de autores estão abreviados de acordo com Brummitt \& Powell (1992). A terminologia geral adotada nas descrições está de acordo com Harris \& Harris (2001) e Radford et al. (1974), a nomenclatura das estípulas foi baseada em Robbrecht (1988) e a nomenclatura da venação das folhas baseada em LAWG (Leaf... 1999). As ilustrações foram elaboradas com o auxílio de estereomicroscópio Medilux MDL-F e processadas através do programa Adobe Photoshop CS4. Os mapas foram elaborados com os programas ArcView, versão 10.0 e AutoCAD, versão 17.1 .

\section{Resultados e Discussão}

As Rubiaceae foram representadas na Serra da Fumaça por 36 espécies e 20 gêneros (Figuras 3, 4, 5, 6, 7 e 8). Os gêneros mais diversos foram Borreria G.Mey. (5 spp.), Diodella Small, Mitracarpus Zucc. ex Schult. \& Schult.f. e Psychotria L. (3 spp. cada), seguidos por Coccocypselum P.Browne, Declieuxia Kunth, Palicourea Aubl., Perama Aubl., Richardia L. e Staelia Cham. \& Schltdl. (2 spp. cada). Os demais gêneros, Cordiera A.Rich. ex DC., Coutarea Aubl., Emmeorhiza Pohl ex Endl., Genipa L., Guettarda L., Malanea Aubl., Manettia Mutis ex L., Posoqueria Aubl., Sabicea Aubl., Tocoyena Aubl., apresentaram apenas uma espécie cada.

Quanto ao hábito, predominaram as espécies herbáceas (Figura 2), geralmente associadas a áreas abertas de caatinga e campo rupestre, ou ao subosque da floresta. O domínio das espécies herbáceas se deve possivelmente à diversidade da tribo Spermacoceae que representa a maioria das espécies. De acordo com Cabral \& Bacigalupo (1999), esse grupo tem o Brasil como maior centro de diversidade na América. 


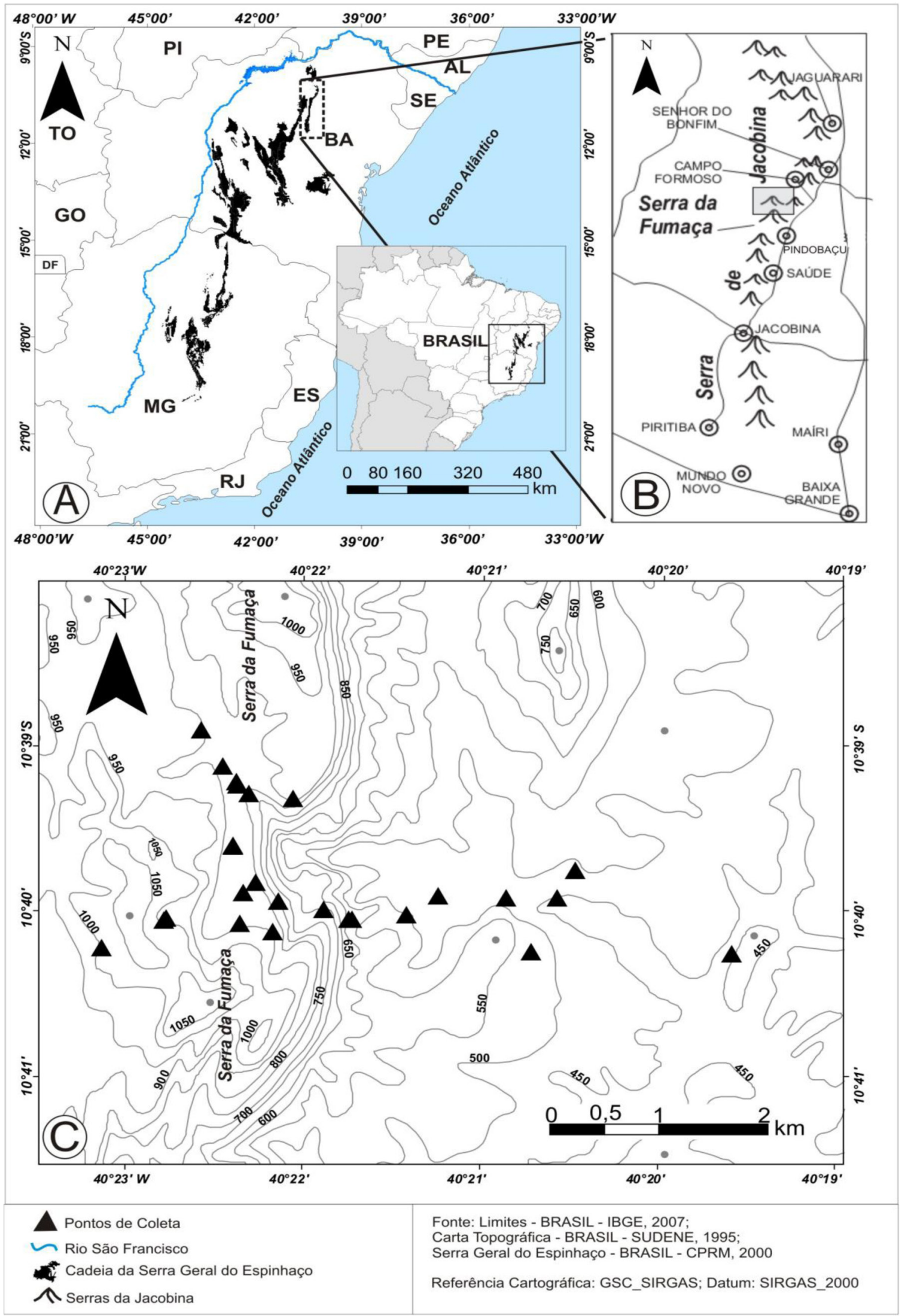

Figura 1. Mapa de localização da área de estudo. A - Localização da Serra Geral do Espinhaço com destaque para o Complexo de Serras da Jacobina. B - Localização da Serra da Fumaça, Pindobaçu, Bahia. C - Carta topográfica da Serra da Fumaça com as curvas de nível e detalhes dos pontos de coleta.

Figure 1. Location map of the study area. A - Location of the Serra Geral do Espinhaço, featured the Mountains complex of Jacobina. B - Location of the Serra da Fumaça, Pindobaçu, Bahia. C - Letter topographic of the Serra da Fumaça with the contours and details of collection points. 


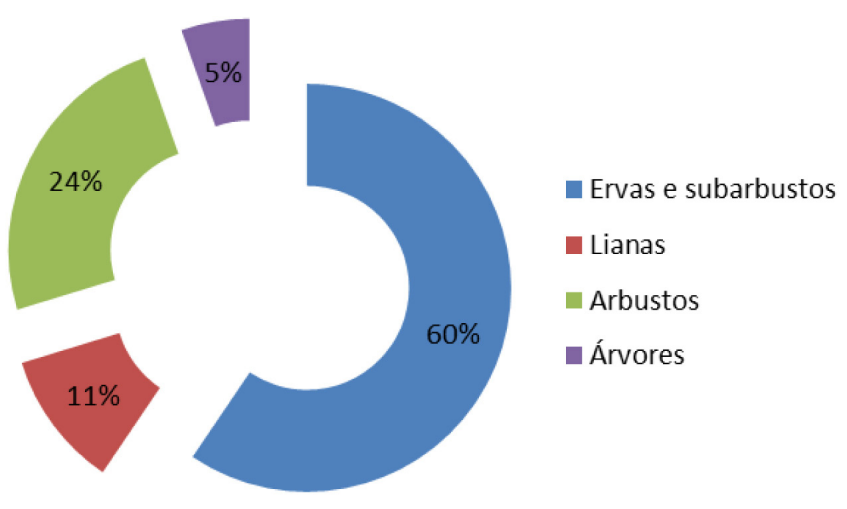

Figura 2. Distribuição das espécies de Rubiaceae quanto às formas de vida (hábito) na Serra da Fumaça, Pindobaçu, Bahia.

Figure 2. Distribution of species of Rubiaceae on as life forms (habit) in Serra da Fumaça, Pindobaçu, Bahia.

As áreas com fitofisionomias de cerrado situadas acima de $600 \mathrm{~m}$ de altitude se destacaram quanto ao número de espécies $(41 \%)$ do total, seguidas por áreas de caatinga na base da serra, abaixo de $500 \mathrm{~m}$, com $32 \%$ das espécies. As áreas com floresta de galeria abaixo de $500 \mathrm{~m}$ de altitude e a floresta estacional acima de $800 \mathrm{~m}$ somaram $27 \%$ das espécies.

Perama harleyi J.H.Kirkbr. \& Steyerm. é endêmica da Bahia e conhecida apenas para a Chapada Diamantina, enquanto que Guettarda sericea Müll.Arg., apenas para áreas de caatinga do nordeste brasileiro. Já Psychotria jambosioides Schltdl. é endêmica da Mata Atlântica, ocorrendo apenas na Bahia e no Espírito Santo, onde era conhecida até então apenas nas florestas litorâneas, incluindo a restinga. Psychotria mapourioides DC., possui distribuição ampla (Amazônia e Mata Atlântica). Estas duas últimas espécies constituem novos registos para a Cadeia do Espinhaço. Giulietti \& Pirani (1988) destacaram que algumas espécies originárias da Cadeia do Espinhaço, podem ser encontradas nas restingas ao longo da costa atlântica brasileira.

Chave para identificação das espécies de Rubiaceae encontradas na Serra da Fumaça, Pindobaçu, Bahia

1. Árvores ou arbustos.

2. Estípulas bipartidas, se inteiras, espatuladas ou ovadas.

3. Estípulas decíduas, inteiras, espatuladas a ovadas, ápice arredondado a obtuso 30. Psychotria mapourioides

3'. Estípulas persistentes, bífidas, ápice agudo.

4. Folhas com venação secundária inconspícua; pedúnculo espesso, branco ou lilás..... 29. Psychotria jambosioides

4'. Folhas com venação secundária saliente; pedúnculo delgado, amarelo ou vermelho.

5. Folhas com 60-130 mm compr., pubescentes em ambas as faces; corola externamente pubescente

24. Palicourea marcgravii

5'. Folhas (65-)120-180 mm compr., glabras em ambas as faces; corola externamente glabra

23. Palicourea guianensis

2’. Estípulas inteiras, triangulares ou lineares.

6. Ramos sem lenticelas visíveis; fruto bacáceo ou esquizocárpico.
7. Estípulas lineares; folhas pseudoverticiladas por apresentar braquiblastos; frutos esquizocarpos 10. Declieuxia aspalathoides

7'. Estípulas triangulares; folhas opostas sem braquiblastos, frutos bacáceos.

8. Lâmina foliar com (18-)30-83 mm compr.; flores diclinas, tubo da corola com 5-8 mm compr.; frutos com 5-14 $\times 5-12 \mathrm{~mm}$

8. Cordiera elliptica

8'. Lâmina foliar $\geq 90 \mathrm{~mm}$ compr.; flores monoclinas, tubo da corola $\geq 20 \mathrm{~mm}$ compr.; frutos com $18-100 \times 15-80 \mathrm{~mm}$.

9. Folhas e ramos jovens densamente pubescentes; tubo da corola externamente pubescente.

36. Tocoyena formosa

9'. Folhas e ramos glabros ou folhas hirsutas a pubescentes; tubo da corola externamente glabro.

10. Lâmina foliar com $80-130 \mathrm{~mm}$ compr.; estípulas persistentes, geralmente cariosas

27. Posoqueria latifolia

10'. Lâmina foliar com 220-250 mm compr.; estípulas decíduas, triangulares.

16. Genipa americana

6'. Ramos visivelmente lenticelados; frutos drupáceos ou capsulares.

11. Flores com tubo da corola com $15-18 \mathrm{~mm}$ compr.; frutos cápsulas septicidas.

9. Coutarea hexandra

11' Flores com tubo da corola com 2-3,5 mm compr.; frutos drupáceos.

12. Ramos apoiantes, espinescentes; inflorescências escorpioides; frutos rugosos vináceos a negros após a maturação 17. Guettarda sericea

12' Ramos eretos, inermes; inflorescências tirsoides; frutos costados, laranja a vermelhos após a maturação 30. Psychotria mapourioides

1'. Ervas, subarbustos ou lianas.

13. Lianas ou trepadeiras.

14. Folhas e ramos apicais densamente pubescentes; frutos bacáceos vermelhos após maturação..... 33. Sabicea grisea

14'. Folhas e ramos glabros raro hirsutos; frutos capsulares ou drupáceos, castanhos, marrons ou atropurpúreos na maturação.

15. Estípulas fimbriadas; folhas com venação marcadas a plicadas na face superior; inflorescências umbeliformes 15. Emmeorhiza umbellata

15'. Estípulas triangulares; folhas com venação levemente marcada a marcada apenas na face superior, nunca plicada; inflorescências em panículas e cimeiras.

16. Estípulas decíduas, presentes apenas em botão, ápice arredondado; inflorescências em panículas, multifloras; frutos drupas 18. Malanea macrophylla

16'. Estípulas persistentes, ápice agudo; inflorescências em cimeiras, uniflora; frutos cápsulas 19. Manettia cordifolia

13'. Ervas a subarbustos.

http://www.biotaneotropica.org.br/v13n3/pt/abstract?inventory+bn02313032013 
17. Estípulas inteiras, ou reduzidas a uma linha.

18. Erva ereta, caule delicado com até $30 \mathrm{~cm}$ alt.; estípula reduzida a uma linha; corola rósea ou amarela.

19. Caule hirsuto; corola amarela; inflorescências em glomérulos congestos..... 26. Perama hirsuta

19'. Caule glabro ou com tricomas adpressos apenas no ápice; corola rósea; inflorescências dicasiais, laxas 25. Perama harleyi

18'. Subarbustos eretos ou ervas decumbentes; caule robusto maior que $30 \mathrm{~cm}$ alt.; estípulas inteiras, corola azul.

20. Caule lenhoso, ereto; frutos esquizocarpos, dicoca, castanhos na maturação.

21. Folhas lineares, pseudoverticiladas pela presença de braquiblastos 10. Declieuxia aspalathoides

21'. Folhas oblanceoladas a oblongo-elípticas, opostas, sem formar braquiblastos

11. Declieuxia fruticosa

20'. Caule herbáceo, decumbente; frutos bacáceos, inteiros, azuis a lilases na maturação.

22. Folhas hirsutas, 4-6 pares de nervuras secundárias; glomérulos com 36(7)-flores; cálice com lobos eretos . 6. Coccocypselum hirsutum

22'. Folhas velutinas a denso velutinas, 7-8 pares de nervuras secundárias; glomérulos com 10-17-flores; cálice com lobos reflexos 7. Coccocypselum lanceolatum

17’. Estípulas bífidas ou fimbriadas, nunca reduzidas a apenas uma linha.

23. Estípulas bífidas 28. Psychotria hoffmannseggiana

23'. Estípulas fimbriadas

24. Flores hexâmeras; estigmas trífidos.

25. Tubo da corola com $3-5,5 \mathrm{~mm}$ compr.; frutos com três mericarpos sutilmente sulcados, dorso com papilas arredondadas

32. Richardia grandiflora

25'. Tubo da corola com 2-3 mm compr.; frutos com três mericarpos profundamente sulcados, dorso com papilas lanceoladas

31. Richardia brasiliensis

24'. Flores tetrâmeras e pentâmeras estigmas inteiros ou bilobados.

26. Frutos esquizocárpicos.

27. Bainha estipular com setas glabras; fruto piloso apenas no ápice, mericarpo com a face ventral lisa

13. Diodella radula

27'. Bainha estipular com setas pilosas; fruto completamente piloso a híspido, mericarpo com a face ventral com duas depressões.

28. Folhas com nervuras secundárias visíveis em ambas as faces; cálice com lobos iguais, corola 4-10 mm compr.; frutos com a face dorsal dos mericarpos com 3-5 costelas

12. Diodella apiculata

28'. Folhas com nervuras secundárias inconspícuas; cálice com lobos desiguais, corola até $4 \mathrm{~mm}$ compr.; frutos com a face dorsal dos mericarpos com 1-(3) costelas

14. Diodella teres
26'. Frutos capsulares.

29. Cálice com lobos de comprimento iguais; corola infundibuliforme; estames exsertos; cápsula com deiscência longitudinal ou longitudinal-oblíqua.

30. Tubo da corola externamente glabro; cápsula com deiscência longitudinal, valvas unidas na base, persistentes.

31. Folhas pseudoverticiladas por apresentar braquiblastos nas axilas.

32. Cálice com 4 lobos; estigma capitado........1. Borreria capitata

32'. Cálice com 2 lobos iguais; estigma bilobado.

33. Estípulas com 5-7 setas; folhas com 2 pares de nervuras secundárias; glomérulos globosos.....

5. Borreria verticillata

33'. Estípulas com 7-9 setas; folhas com 4-5 pares de nervuras secundárias; glomérulos subglobosos 4. Borreria spinosa

31'. Folhas opostas, sem braquiblastos.

34. Caule jovem tetrágono, alado; folhas sésseis; flores nos dois lados das axilas das folhas; tubo da corola 3,5-6 $\mathrm{mm}$ compr.

2. Borreria latifolia

34'. Caule jovem cilíndrico, sem alas; folhas pecioladas; flores em apenas um dos lados das axilas das folhas; tubo da corola 2-3 mm compr

3. Borreria ocymifolia

30'. Tubo da corola externamente papiloso ou hirsuto; cápsula com deiscência longitudinal-oblíqua, valvas totalmente livres, decíduas.

35. Caule tomentoso-viloso; lâmina foliar com a face superior escabra; corola 4-4,5 mm compr. 34. Staelia vestita

35'. Caule glabro a pubérulo; lâmina foliar com face superior glabra a pilosa; corola $6,8-7,2 \mathrm{~mm}$ compr 34. Staelia virgata

29'. Cálice com lobos de comprimento desiguais; corola hipocrateriforme; estames inclusos; cápsula com deiscência transversal.

36. Tubo da corola com $3,5-4,8 \mathrm{~mm}$ compr.; semente com face ventral com encaixe em forma de "y invertido", face dorsal sem depressões

23. Mitracarpus salzmannianus

36'. Tubo da corola com 1,2-3,5 mm compr.; semente com face ventral com encaixe em forma de "X", face dorsal com depressões cruciformes.

37. Caule tetragonal, fortemente alado; folhas pseudoverticiladas pela presença de braquiblastos; tubo da corola 3-3,5 mm compr 22. Mitracarpus frigidus

37'. Caule cilíndrico, sem alas; folhas opostas cruzadas, sem formar braquiblastos; tubo da corola 1,2-1,5 $\mathrm{mm}$ compr 21. Mitracarpus baturitensis

Tratamento taxonômico

Rubiaceae Juss., Genera Plantarum 196. 1789.

Árvores, arbustos ou ervas, ocasionalmente trepadeiras, raro epífitas. Ramos, cilíndricos, às vezes angulosos ou decussadamente achatados, glabros ou pilosos. Estípulas interpeciolares, raramente intrapeciolares (Elaeagia Wedd. e Capirona Abeto), ou reduzida a uma linha em Perama Aubl., persistentes ou decíduas, livres ou concrescidas entre si, inteiras, bipartidas, fimbriadas ou foliáceas. 
Inflorescências terminais ou axilares, geralmente cimosas, multifloras ou paucifloras, raramente flores solitárias; brácteas e bractéolas frequentemente decíduas. Folhas simples, inteiras, opostas, raro pseudo-alternas ou pseudoverticiladas, sésseis ou pecioladas. Flores monoclinas ou unissexuais, distilia presente ou não, actinomorfas, raro zigomorfas, isostêmones, diclamídeas, simpétalas, livre em Dialypetalanthus, (3)4-6 ou 11-13(-15) mera; cálice truncado, denteado, comumente lobado; corola hipocrateriforme, infundibuliforme, campanulada ou tubulosa, de prefloração valvar, contorta ou imbricada; estames epipétalos 4-5, inclusos ou exsertos, anteras geralmente rimosas, e livres entre si, excepcionalmente poricidas, dorsifixas ou basifixas; ovário ínfero, excepcionalmente semi-ínfero, dois, raramente três carpelos, dois ou mais lóculos, raramente um lóculo, um a muitos óvulos por lóculo, placentação apical, basal ou axial; disco nectarífero inteiro ou bipartido, anular, carnoso, raro reduzido a glândulas; estilete usualmente inteiro; estigma clavado, dilatado, capitado, truncado, discoide, bilobado ou bífido com papilas estigmáticas uniformemente distribuídas. Frutos deiscentes capsulares ou indeiscentes com pericarpo seco ou carnoso, bacáceos, drupáceos, capsulares e esquizocárpicos; sementes uma a numerosas, plana, angulosa, reniforme, semicilíndrica, com ou sem alas, sulcada ou não; endosperma, carnoso ou córneo, parco ou ausente.

\section{Borreria capitata (Ruiz \& Pav.) DC., Prodr. 4: 545. 1830.}

Erva ereta a procumbente, $30-60 \mathrm{~cm}$ alt., monoica; caule cilíndrico a tetrágono no ápice, sem lenticelas, pubescente, entrenós 6-30 mm compr. Estípulas fimbriadas, persistentes, bainha 2-2,5 × 3,5 Este trabalho consiste no levantamento $\mathrm{mm}$, pubescentes, 5-8 setas, 3-6 mm compr., glabras. Folhas pseudoverticiladas devido aos braquiblastos nas axilas, cartáceas, sésseis; lâmina 24-50 × 5-8 mm, elíptica a lanceolada, base atenuada ou obtusa, ápice agudo, margem plana; ambas as faces pubescentes, venação eucamptódroma, nervuras secundárias impressas na face adaxial, salientes na face abaxial, 4-6 pares. Inflorescências em glomérulos globosos, terminais ou axilares, 2-4 por ramo florífero, multifloros; 4-6 brácteas foliáceas, lanceoladas, bractéolas inconspícuas. Flores monoclinas, homostílicas, sésseis; cálice 4 lobos iguais, 1-1,5 mm compr., linear-lanceolados, pubescentes; corola alva a lilás, infundibuliforme; tubo 3-4 mm compr., externamente glabro, anel de tricomas na inserção dos filetes, 4-mera, lobos 0,6-1 mm compr., triangular a ovados, pilosos no ápice; estames exsertos, presos próximo da fouce, porção livre dos filetes 0,5-1 mm compr., anteras, 0,4-0,6 mm compr., oblongo-elípticas, estigma bilobado, disco nectarífero bilobado, estilete, 3,8-4,3 mm compr. Fruto cápsula septicida, 2-3 × 1-1,5 mm, oblongoide, deiscência longitudinal, valvas unidas na base, persistentes, marrom na maturação, glabra a pubérula; sementes 1,2-1,5 × 0,5 mm, elipsoides, castanhas, ruminadas na face dorsal, sulco longitudinal na face ventral.

Distribuição: Está distribuída na Venezuela, Colômbia, Peru, Guiana Francesa e Bolívia (Bacigalupo \& Cabral 2007a, Cabral et al. 2011). No Brasil, ocorre em todas as regiões (Cabral \& Bacigalupo 1999). É encontrada com mais frequência no Cerrado s.l., Mata Atlântica (restinga) e Caatinga (Cabral et al. 2011).

Diferencia-se das demais espécies do gênero presentes na área, por apresentar folhas com nervuras secundárias proeminentes em ambas as faces e disco nectarífero bilobado. Segundo Steyermark (1972), na América do Sul a espécie apresenta grande variação morfológica foliar e no indumento. Foi encontrada áreas abertas da Caatinga perturbada e campo rupestre, entre 460-890 m de altitude. Floresce e frutifica na área nos períodos chuvosos, junho a agosto e novembro.

Material examinado: BRASIL, BAHIA: Pindobaçu, Serra da Fumaça. $10^{\circ} 40^{\prime} 03$ " S e 40²1'30" W, 17/XI/2009, fl., fr., L.A. Sousa
171 (HUNEB); 26/VI/2011, fl., fr., L.A. Sousa 307 (HUNEB); 26/VIII/2011, fl., fr., L.A. Sousa 399 (HUNEB); 10³9' 51' 'S e 40 22' 19”' W, 29/IX/2011, fl., fr., L.A. Sousa 444 (HUNEB).

2. Borreria latifolia (Aubl.) K.Schum., Fl. Bras. 6(6): 61. 1888. Erva decumbente ou ereta, 30-60 cm alt., monoica; caule cilíndrico, tetrágono quando jovens, alado, sem lenticelas, hirsuto, entrenós 8-12 cm compr. Estípulas fimbriadas, persistentes, bainha 1,5-2 mm compr., pubescente, 5-8 setas, 1,5-3 mm compr., hirsutas. Folhas opostas, cartáceas, sésseis; lâmina 25-70 × 15-30 cm, elíptica, lanceolada a oblanceolada, base atenuada, ápice agudo, margem plana; face adaxial escabra a hirsuta, abaxial hirsuta a denso-hirsuta nas nervuras; venação eucamptódroma, nervuras proeminentes na face abaxial, 3-5 pares. Inflorescências em glomérulos axilares, 3-4-flores; 2 brácteas foliáceas lanceoladas, bractéolas inconspícuas. Flores monoclinas, homostílicas, sésseis; cálice 4 lobos iguais, 1,5-2,5 mm compr., lanceolados, hirsuto no ápice; corola alva ou azulada, infundibuliforme, tubo 3,5-6 mm compr., glabro externamente, anel de tricomas na inserção dos filetes, 4-mera, lobos 1-2 mm compr., ovados, esparso hirsuto; estames excertos, inseridos na fauce da corola, porção livre dos filetes 1-1,5 mm compr.; anteras oblongas, 1,8-2 mm compr.; estigma bífido, estilete 7-9 mm compr. Fruto cápsula septicida 3,8-4 × $2 \mathrm{~mm}$, oblongoide, deiscência longitudinal, valvas unidas na base, persistentes, marrom quando madura, ápice piloso. Semente $1,8 \times 0,6-0,8 \mathrm{~mm}$, plano convexa, superfície dorsal reticulada, superfície ventral com sulco longitudinal.

Distribuição: Distribui-se na América Central e na maior parte da América do Sul (Chaw \& Peng 1987). No Brasil, ocorre em quase todo o país nos domínios da Amazônia, Caatinga, Cerrado, Mata Atlântica e Pampa. Na Bahia, é encontrada em todos os biomas, especialmente em áreas de Cerrado e Campo rupestre (Cabral et al. 2011).

Borreria latifolia diferencia-se B. ocymifolia, espécie mais semelhante presente na área, por apresentar caule tetragono e alado quando jovem e flores em ambos os lados das axilas vs caule cilíndrico, sem alas e flores unilaterais. Segundo Cabral et al. (2011), esta espécie possui uma grande variação quanto ao tipo de folha e de indumento. Foi encontrada na área, associada à floresta de galeria, sobre solo argiloso. Floresce e frutifica nos meses de junho e julho.

Material examinado: BRASIL. BAHIA: Pindobaçu, Serra da Fumaça. $10^{\circ} 39$ ' 59" S e 40²1' 59"' W, 28/VI/2011, fl., L.A. Sousa 366 (HUNEB); 28/VII/2012 fl., fr. L.A. Sousa 607 (HUNEB).

3. Borreria ocymifolia (Roem. \& Schult.) Bacigalupo \& E.L.Cabral, Opera Bot. Belg. 7: 297. 1996.

Figura 3A-E

Erva a subarbusto ereto, $30-60 \mathrm{~cm}$ alt., monoica; caule cilíndrico, sem lenticelas, hirsutos, entrenós 20-60 mm compr. Estípulas fimbriadas, persistentes, bainha 4-8 $\times 3,5 \mathrm{~mm}$ compr., hirsuta a híspida, 5-6 setas desiguais, 0,8-6 mm compr. Folhas opostas, cartáceas, pecíolos 0,5-1,8 mm, híspidos; lâmina 18-50 × 5-20 mm, oblanceolada a lanceolada, base atenuada, ápice agudo, margem plana; face adaxial pubérula a escabra, abaxial escabra a híspida; venação broquidódroma, nervuras secundárias proeminentes na face abaxial, levemente impressa na face adaxial, 3-8 pares. Inflorescências em glomérulos, axilares, raramente terminais, unilaterais, 4-8 por ramo florífero, multifloros; 2 brácteas foliáceas, elípticas, 2 bractéolas, filiformes. Flores monoclinas, homostílicas, sésseis; cálice 4 lobos iguais, 0,5-1,5 mm compr., triangulares a subulados, híspidos; corola alva, infundibuliforme , tudo 2-3 mm compr., externamente glabro, um anel de tricomas na inserção dos filetes, 4-mera, lobos 2-3 mm compr., oblongos a ovados, pilosos no ápice; estames exsertos, inseridos na fauce; porção livre dos filetes 1-2 mm compr., anteras, 0,5-0,7 mm compr., elípticas, alvas; estigma bilobado, estilete exserto, 4-5 mm compr. Fruto cápsula septicida, 2-2,2 × 0,8-1 mm, elíptica, oblongoide, deiscência longitudinal,valvas unidas na base, marrons, 
persistentes, híspida a escabra; sementes 1,5-2,5 × 0,3-0,6 mm, elípticas ou oblongas, castanho-escuras, faveoladas na face dorsal, sulco longitudinal na face ventral.

Distribuição: Está distribuída por toda a região Neotropical (Andersson 1992). No Brasil, ocorre em todas as regiões, nos estados do Amazonas, Pará, Tocantins, Bahia, Ceará, Goiás, Distrito Federal, São Paulo e Santa Catarina (Cabral et al. 2011).

Caracteriza-se por apresentar inflorescências unilaterais e caule ereto, cilíndrico, sem alas, características que a diferencia de Borreria latifolia. Foi coletada somente na base da serra a $490 \mathrm{~m}$ de altitude, em áreas sombreadas, no interior da floresta de galeria nas margens do rio Fumaça, sobre solo argiloso. Floresce e frutifica em quase todos os meses do ano.

Material examinado: BRASIL. BAHIA: Pindobaçu, Serra da Fumaça. $10^{\circ} 39$ ' 59' S e 40²1' 59' W, 28/VI/2011, fl., fr., L.A. Sousa 368 (HUNEB); 28/VIII/2011, fl., fr., L.A. Sousa 368 (HUNEB); 29/ IX/2011, fl., fr., L.A. Sousa 428 (HUNEB); 15/XII/2011, fl., fr., L.A. Sousa 454 (HUNEB); 20/I/2012, fl., fr., L.A. Sousa 512 (HUNEB); 28/ VII/2012, fl., fr., L.A. Sousa 608 (HUNEB); $10^{\circ} 39^{\prime} 54^{\prime \prime}$ S e 40²0' 51 " W, 12/IV/2006, fl., R.F. Souza-Silva \& V.J. Santos 148 (ALCB, HUEFS); Pindobaçu, margem do rio Fumaça, 12/IV/2006, fl., V.J. Santos 514 (HUEFS).

4. Borreria spinosa (L.) Cham. \& Schltdl., Linnaea 3: 340. 1828. Figura 3F-H

Erva ereta, ca. $20 \mathrm{~cm}$ alt., monoica, caule tetragonal, sem lenticelas, glabro, entrenós 10-50 mm compr. Estípulas fimbriadas, persistentes, bainha 2,5-4 × 3-3,5 mm, glabra a pubescente, 7-9 setas, 3-5 mm compr., glabras. Folhas pseudoverticiladas devido aos braquiblastos nas axilas, cartáceas, sésseis; lâmina 10-20 × 4-8 mm, elíptico a lanceolado, base atenuada, ápice agudo, margem plana; ambas as faces glabras, face abaxial com papilas na nervura central; venação eucamptódroma, nervuras secundárias conspícuas em ambas as faces, 4-5 pares. Inflorescências em glomérulos subglobosos, terminais e axilares, 1-3 por ramo florífero, multifloros; 2-4 brácteas foliáceas, bractéolas inconspícuas. Flores monoclinas, homostílicas, sésseis; cálice 2 lobos iguais, 1,6-2 mm compr., lanceolados, hirsutos; corola alva, infundibuliforme, tubo 1,5-2 mm compr., glabro externamente, anel de tricomas na inserção dos filetes, 4-mera, lobos 1-1,2 mm compr., triangulares a ovados, glabros; estames exsertos, porção livre dos filetes $1 \mathrm{~mm}$ compr., anteras, 0,6-0,8 mm compr., oblongo-elípticas; estigma curtamente bífido, estilete 1,4-2 mm compr. Fruto cápsula septicida, 2,5-3 × 1-1,2 mm, oblongoide cápsula com deiscência longitudinal, valvas unidas na base, persistentes, marrom na maturação, ápice piloso; sementes 1,5 × 0,4-0,6 mm, oblongas, castanhas, reticulada na face dorsal, sulco longitudinal na face ventral.

Distribuição: Espécie amplamente distribuída na América, desde o México, Antilhas até a Argentina. No Brasil, ocorre em todas as regiões nos domínios do Cerrado e da Caatinga (Cabral \& Salas 2012a).

Borreria spinosa pode ser confundida $\operatorname{com} B$. verticillata da qual se diferencia pelo maior número de setas na estípula (7-9 vs 5-7), pelo maior número de nervuras secundárias (4-5 vs 2) e através da forma dos glomérulos (subglobosos vs globosos). Foi encontrada na área, apenas no período chuvoso, associada a áreas abertas de Caatinga com solo argiloso a $480 \mathrm{~m}$ altitude. Foi encontrada com flores e frutos em junho.

Material examinado: BRASIL. BAHIA: Pindobaçu, Serra da Fumaça, $10^{\circ} 39^{\prime} 53,6^{\prime}$ ' S e $40^{\circ} 22^{\prime} 20^{\prime}$ ' W, 28/VII/2011, fl., fr., L.A. Sousa 355 (HUNEB).

Material adicional examinado: BRASIL. BAHIA: Jaguarari, estrada para Grotas, Caminho do Engenho, 24/VI/2005, fl., R.F. Souza-Silva \& A. Rapini 22 (HUEFS); Base da Crista, próximo ao
Rio, 13/IV/2006, fl., E.B. Souza et al. 200 (HUEFS); Lençóis 08/ IX/2005, fl., E.B. Souza et al. 1406 (HUEFS); Senhor do Bonfim, 28/IV/2005, fl., J.G. Freitas \& V. Barreto14 (HUNEB).

5. Borreria verticillata (L.) G.Mey., Prim. Fl. Esseq. 83. 1818.

Erva ou subarbusto ereto, 30-60 cm alt., monoica; caule cilíndrico na base, ápice tetrágono, com papilas aculeadas, sem lenticelas, glabro, entrenós 6-30 mm compr. Estípulas fimbriadas, persistentes, bainha 2-3 $\times 3 \mathrm{~mm}$, pubescente, 5-7 setas, $1-3 \mathrm{~mm}$ compr., pubérula. Folhas pseudoverticiladas devido aos braquiblastos nas axilas, cartáceas, sésseis; lâmina $8-40 \times 1,8 \mathrm{~mm}$, lanceolada, elíptica a estreito-elíptica, base cuneada, ápice agudo, margem plana; ambas as faces glabras, nervura híspida com papilas na face abaxial; venação eucamptódroma, nervuras secundárias inconspícuas na face adaxial, 2 pares. Inflorescências em glomérulos globosos, terminais, subterminais e axilares, 1-3 por ramo florífero, multifloros; 2-4 brácteas foliáceas, bractéolas inconspícuas. Flores monoclinas, homostílicas, sésseis; cálice 2 lobos iguais, 1-2 mm compr., lanceolados, margem plana; corola alva, infundibuliforme, tubo 1-2 mm compr., glabro externamente, anel de tricomas na inserção dos filetes, 4-mera, lobos 1-1,2 mm compr., triangulares, glabros; estames exsertos, inseridos na fouce, porção livre dos filetes 0,8-1 mm compr., anteras 0,7-1 mm compr., oblongo-elípticas; estigma bífido, estilete 0,8-2,2 mm compr. Fruto cápsula septicida, 2-2,8 × 1-1,2 mm, oblongoide, cápsula com deiscência longitudinal, valvas unidas na base, persistentes, marrom na maturação, glabro a pubérulo; sementes 0,7-1,8 $\times 0,6 \mathrm{~mm}$, elipsoides, castanhas, faveoladas na face dorsal, sulco longitudinal na face ventral.

Distribuição: Ocorre desde o Sul dos Estados Unidos até a parte meridional da América do Sul, Antilhas e Velho Mundo (Burger \& Taylor 1993). Ocorre com ampla distribuição no Brasil, sendo representada na maioria dos estados (Dimitri 1959, Andersson 1992).

Borreria verticillata é muito semelhante a B. spinosa tanto em campo como em material herborizado, mas se diferencia por apresentar ramos eretos geralmente pouco ramificados ou com ramificação apical, maior número de setas na estípula, folhas com apenas duas nervuras secundárias e glomérulos globosos e geralmente menores. Foi encontrada em áreas abertas, perturbadas, na base da serra entre 490-540 m de altitude. Floresce e frutifica em quase todos os meses do ano.

Material examinado: BRASIL. BAHIA: Pindobaçu, Serra da Fumaça. $10^{\circ} 39$ ' 54" S e $40^{\circ} 21$ ' 14" W, 12/IV/2006, fl., V.J. Santos 520 (HUEFS); $10^{\circ} 39^{\prime} 53,6^{\prime}$ 'S e 40²2' 20" W, 24/I/2009, fl., fr., L.A. Sousa 313 (HUNEB); 30/VI/2011, fl., fr., L.A. Sousa 340 (HUNEB); 28/VI/2011, fl., fr., L.A. Sousa 316 (HUNEB); 28/IV/2011, fl., fr., L.A. Sousa 315 (HUNEB 26/VII/2011, fl., fr., L.A. Sousa 394 (HUNEB); 2/ VIII/2011, fl., fr., L.A. Sousa 421 (HUNEB); 29/IX/2011, fl., fr., L.A. Sousa 427 (HUNEB); 15/XII/2011, fl., fr., L.A. Sousa 484 (HUNEB); 26/XII/2011, fl., fr., L.A. Sousa 495 (HUNEB); 20/I/2012, fl., fr., L.A. Sousa 515 (HUNEB); 20/I/2012, fl., fr., L.A. Sousa 513 (HUNEB; $10^{\circ} 39$ ' 54,6" S e $40^{\circ} 22$ ' 20" W, 26/VI/2011, fl., fr., L.A. Sousa 324 (HUNEB); 29/IX/2011, fl., fr., L.A. Sousa 412 (HUNEB); 28/ IX/2011, fl., fr., L.A. Sousa 423 (HUNEB); 29/IX/2011, fl., fr., L.A. Sousa 432 (HUNEB); 26/XII/2011, fl., fr., L.A. Sousa 511 (HUNEB); 18/IV/2012, fl., fr., L.A. Sousa 593 (HUNEB); 27/VII/2011, fl., L.A. Sousa 506 (HUNEB); 17/IV/2012, fl., fr., L.A. Sousa 554 (HUNEB).

6. Coccocypselum hirsutum Bartl. ex DC., Prodr. 4: 396. 1830. Figura 3I-L

Erva decumbente, monoica; caule cilíndrico, sem lenticelas, densamente hirsuto, tricomas alvos, entrenós 50-90 mm compr. Estípulas persistentes, 3,5-5 × 2,8-3,5 mm, inteiras, lineares, hirsutas. Folhas opostas, herbáceas, pecíolo 5-8 mm compr., densamente hirsuto; lamina $38-60 \times 15-25 \mathrm{~mm}$, elíptica a lanceolada, base obtusa, ápice agudo a obtuso, margem plana; ambas as faces hirsutas, 


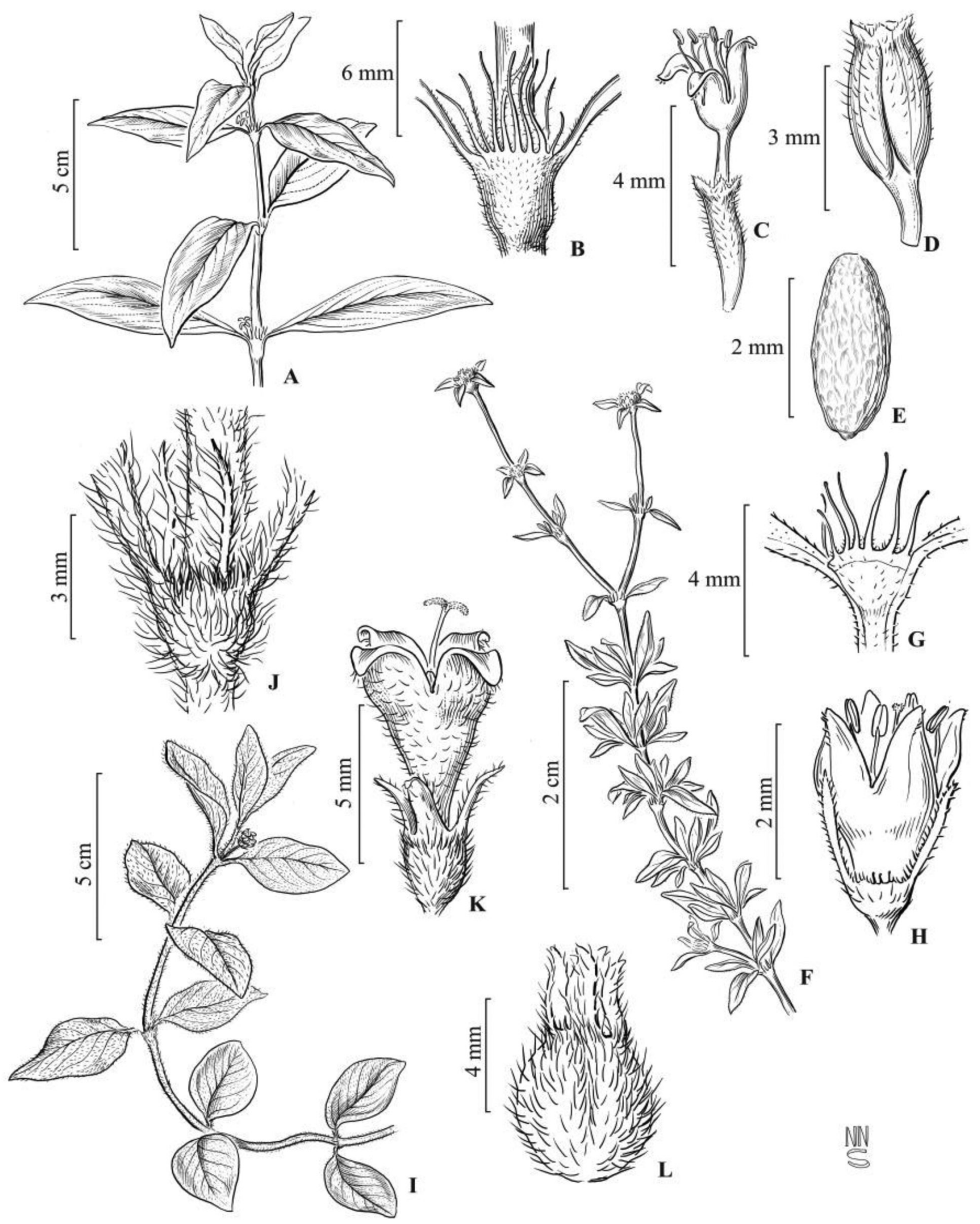

Figura 3. A-E. Borreria ocymifolia - A. ramo florífero; B. estípula; C. flor e hipanto; D. fruto; E. semente. F-H. Borreria spinosa - F. ramo florífero; G. estípula; H flor e hipanto. I-L. Coccocypselum hirsutum - I. ramo florífero; J. estípula; K. flor e hipanto; L. fruto. (A-E. L.A. Sousa 368; F-H. L.A. Sousa 317; I-L. L.A. Sousa 415).

Figure 3. A-E. Borreria ocymifolia - A. flowering branch; B. stipule; C. flower and hypanthium; D. fruit; E. seed. F-H. Borreria spinosa - F. flowering branch; G. stipule; H. flower and hypanthium. I-L. Coccocypselum hirsutum - I. flowering branch; J. stipule; K. flower and hypanthium; L. fruit. (A-D. L.A. Sousa 368; F-H L.A. Sousa 317; I-L L.A. Sousa 415). 
venação broquidódroma, nervuras proeminentes na face abaxial, 4-6 pares. Inflorescências glomérulos, terminais e axilares, 3-6 (7)-flores, pedúnculo 5-15 mm, hirsutos; brácteas foliáceas, lanceoladas, bractéolas inconspícuas. Flores monoclinas, heterostílicas, dimórficas, sésseis; cálice 4 lobos iguais, 3-4,5 mm compr., linearlanceolados, hirsutos, eretos corola azul-claro, hipocrateriforme, tubo 2-3 mm compr., glabro internamente, pubescente externamente, 4-mera, lobos 2,5-3 mm compr., estreito-elípticos, hirsuto-barbados externamente; estames inseridos na fauce; anteras 1,5-2 $\mathrm{mm}$ compr., oblongas; estigma bífidos, flores brevistilas, porção livre dos filetes, 3-3,5 mm; estilete 1,5-2 mm compr.; flores longistilas, porção livre do filetes 1,3-1,5 compr.; estilete 5-6,5 mm compr. Fruto baga, 0,8-1,4 $\times$ 0,5-0,8 cm compr., ovoide, obovoide a elipsoide, azulintenso a lilás na maturação, pubescente; semente 1,3-1,5 mm diâm., superfície dorsal muricada, superfície ventral com sulco longitudinal.

Distribuição: Está distribuída no Brasil em todas as regiões, exceto na Sul, nos estados do Amazonas, Bahia, Distrito Federal, Goiás, Mato Grosso do Sul, Mato Grosso e Minas Gerais, no Campo rupestre, Cerrado s.l.e em floresta ciliar (Costa 2004, dados não publicados)

Coccocypselum hirsutum pode ser confundida com C. lanceolatum da qual se diferencia principalmente pelo indumento das folhas (hirsutas $v s$ velutinas), pela venação secundária das folhas em menor número (4-6 vs 7-8 pares), glomérulo com menor número de flores [3-6 (7) vs 10-17] e através dos lobos do cálice (eretos vs reflexos). Foi encontrada associada a áreas de Cerrado, com solo argiloso a $800-910 \mathrm{~m}$ de altitude. Floresce e frutifica na área em janeiro, fevereiro e dezembro.

Material examinado: BRASIL. BAHIA: Pindobaçu, Serra da Fumaça. $10^{\circ} 39 ' 52,6$ " S e 40 22' 04" W, 29/II/209, fr. L.A. Sousa 254 (HUNEB); 26/I/2012, fl., fr. L.A. Sousa 541 (HUNEB); 10 39' 54,6 " S e $40^{\circ} 22^{\prime} 20^{\prime \prime} \mathrm{W}, 26 / \mathrm{I} / 2011$, fr., L.A. Sousa 516 (HUNEB).

7. Coccocypselum lanceolatum (Ruiz \& Pav.) Pers., Syn. P1. 1: 132.1805.

Figura 4A-D

Erva decumbente, monoica; caule cilíndrico, sem lenticelas, velutino a tomentoso, tricomas alvos, entrenós $10-120 \mathrm{~mm}$ compr. Estípulas persistentes, 3-6 $\times 3-3,5 \mathrm{~mm}$, inteiras, lineares, velutinas. Folhas opostas, herbáceas, pecíolo 4-20 mm compr., velutino; lâmina $30-75 \times 15-40 \mathrm{~mm}$, ovada a elíptica, base arredondada, obtusa, truncada a levemente assimétrica, ápice agudo, margem plana; face adaxial velutina, abaxial denso-velutina; venação broquidódroma, nervuras proeminentes na face abaxial, 7-8 pares. Inflorescências glomérulos, globosos, axilares e terminais, 10-17-flores, pedúnculos 5-7 mm compr., velutinos, brácteas foliáceas, ovais, bractéolas inconspícuas. Flores monoclinas, heterostílicas, sésseis; cálice 4 lobos iguais, 1,8-2,2 mm compr., ovados, lanceolados a oblanceolado, ápice obtuso, velutinos, reflexos; corola azul, infundibuliforme, tubo 2,5-3,8 mm compr., externamente velutinos, 4-mera, lobos 2,5-3 mm compr., triangulares, hirsutos no ápice; estames inseridos na fauce; anteras 1,5-2 mm compr., oblongas; estigma bífido, flores brevistilas, porção livre dos filetes 4-4,5 $\mathrm{mm}$; estiletes $1,5-2 \mathrm{~mm}$ compr., flores longistilas, porção livre dos filetes $1,3-1,5 \mathrm{~mm}$ compr.; estiletes 5-6 mm compr. Fruto baga, 8-14 × 5-8 mm compr., ovoide, obovoide a elipsoide, azul-intenso a lilás na maturação, pubescente; semente 1,3-1,5 mm diâm., superfície dorsal muricada, a ventral com sulco longitudinal.

Distribuição: Se distribui amplamente na região neotropical, ocorrendo desde o Sul do México até a Argentina (Dwyer 1980, Andersson 1992). No Brasil, ocorre em todas as regiões, exceto na Norte (Costa \& Mamede 2002).

Coccocypselum lanceolatum pode ser reconhecido através das folhas com indumento velutino, das nervuras secundárias com 7-8 pares e através dos lobos do cálice reflexos. A presença de cálice reflexo foi apontada por Steyermark $(1967,1974)$ como uma característica importante na delimitação desta espécie. A espécie foi encontrada associada ao subosque da Floresta Estacional, sobre solo argiloso a 800-910 m altitude. Floresce em janeiro, fevereiro, maio, junho e dezembro e frutifica de novembro a junho.

Material examinado: BRASIL. BAHIA: Pindobaçu, Serra da Fumaça. $10^{\circ} 39$ ' 14" S e 40 22' 22"'W, 18/II/2009, fl., fr. L.A. Sousa 108 (HUNEB); 26/VI/2011, fl., fr., L.A. Sousa 337 (HUNEB); 27/ XIII/2011, fl., fr., L.A. Sousa 416 (HUNEB); 15/XII/2011, fl., fr., L.A. Sousa 468 (HUNEB); 20/I/2012, fr., L.A. Sousa 516 (HUNEB); 20/I/2012, fl., fr., L.A. Sousa 528 (HUNEB); $10^{\circ} 39^{\prime} 54,6$ " S e $40^{\circ}$ 22 ' 20" 'W, 26/VI/2011, fr., L.A. Sousa 334 (HUNEB); 10 40' 14”' $\mathrm{S}$ e $40^{\circ} 22^{\prime}$ 05" W, 19/V/2012, fr., L.A. Sousa 595 (HUNEB).

8. Cordiera elliptica (Cham.) Kuntze, Revs. Gen. Pl. 1: 279. 1891.

Figura 4E-H

Arbusto, 1,8-3 m alt., dioico; caule cilíndrico, sem lenticelas, glabro, entrenós 15-60 mm compr. Estípulas decíduas, 2-4 × 2-3,8 mm, inteiras, triangulares, livres ou conadas na base, ápice aristado, glabra. Folhas opostas, coriáceas, pecíolo 3-7 mm compr., glabro; lâmina (18)30-83 × (1)20-65 mm, ovada a elíptica, base arredondada a obtusa, ápice acuminado a cuspidado, margem plana, glabra; venação broquidódroma, nervuras secundárias proeminentes na face abaxial, 5-9 pares. Inflorescências masculinas, fasciculadas, terminais, 3-8-flores, as femininas unifloras, sésseis; 2 brácteas foliáceas, lanceoladas, bractéolas inconspícuas. Flores diclinas, homostílicas, sésseis; flores masculinas, cálice truncado, 2-3 mm compr., glabro a seríceo; corola hipocrateriforme, alvas com lobos róseos, tubo 5-8 $\mathrm{mm}$ compr., pilosos externamente, anel de tricomas na fouce, 5-mera, lobos 2-3 mm compr., estreito-ovados, pubérulos; estames, inclusos, inseridos na base do tudo, porção livre dos filetes $0,5-0,6 \mathrm{~mm}$ compr., anteras oblongas, 3-3,5 mm compr.; estigma bífido, estilete $6 \mathrm{~mm}$ compr.; flores femininas, cálice truncado 3-4 mm compr., glabros; corola alvas com lobos róseos, hipocrateriforme, tubo 4-5 mm compr., piloso internamente, tricomas moniliformes na fauce, 5-mera, lobos 2-3 mm compr., oblongos, pilosos; estames, inclusos, inseridos na base do tudo, porção livre dos filetes, 0,3-0,5 mm compr., anteras 2,5-2,8 mm compr., oblongas, sem pólen; estigma bífido, estilete $7-7,5$ compr. Fruto baga, 5-14 $\times 5-12 \mathrm{~mm}$, globosa, marrom-escura na maturaçãoa, glabra; sementes 3,5-4 × 2,5-3,5 mm, retangulares, exotesta lisa.

Distribuição: Espécie endêmica do Brasil, ocorrendo nas regiões Centro-Oeste, Nordeste e Sudeste, nos estados da Bahia, Distrito Federal, Goiás Mato Grosso, Mato Grosso do Sul, Minas Gerais e Pará (Delprete \& Cortés-B 2006, Pessoa \& Zappi 2012).

Caracteriza-se por apresentar as folhas com venação fortemente reticulada, com coloração contrastante na face superior. Em herbário pode ser confundida com Cordiera rigida (K.Schum.) Kuntze, da qual se diferencia por apresentar folhas cartáceas, glabras, fosca na face superior com venação secundária aparente e margem plana. Enquanto que $C$. rigida apresenta folhas coriáceas com a face superior lustrosa, vernicosa, venação secundária inconspícua e margem revoluta, pilosas na face inferior. A espécie encontra-se bem distribuída em áreas de borda ou interior de florestas, sobre solo arenoso a argiloso, entre $840-930 \mathrm{~m}$ de altitude. Floresce nos meses de setembro, outubro e fevereiro, e frutifica em outubro, janeiro, fevereiro e setembro.

Material examinado: BRASIL. BAHIA: Pindobaçu, Serra da Fumaça. $10^{\circ} 39$ ' 54,6" S e 40²2' 20"' W, 29/IX/2011, fl., L.A. Sousa 452 (HUNEB); 29/IX/2011, fl., L.A. Sousa 451 (HUNEB); 29/II/2009, fr., L.A. Sousa 242 (HUNEB); 10 39' 54,6”' S e 40²2' 20" 'W, 29/ IX/2011, fr., L.A. Sousa 497 (HUNEB); 01/XI/2011, fr., L.A. Sousa 462 (HUNEB); 20/I/2012, fr., L.A. Sousa 531 (HUNEB); 20/I/2012, fl., L.A. Sousa 532 (HUNEB). 

1889

9. Coutarea hexandra (Jacq.) K.Schum., Fl. Bras. 6 (6): 196.

Arbusto ou arvoreta, 0,8-7 m alt., monoica; caule cilíndrico, lenticelado, glabro, entrenós 5-40 mm compr. Estípulas persistentes, 2-2,5 $\times 3-3,5 \mathrm{~mm}$, inteiras, triangulares, ápice acuminado, margens pubescentes. Folhas opostas, cartáceas, pecíolos 3-6 mm compr., glabros; lâmina (25)40-60 × (15)28-40, ovado-elíptica, oblanceolada a lanceolada, base aguda a cuneada, ápice agudo, margem plana, glabras; venação broquidódroma, nervuras secundárias proeminentes na face abaxial, 4-6 pares. Inflorescências panículas, terminais, 4-5-flores, pedúnculo 4-10 mm compr.; 2 brácteas foliáceas, lineares, bractéolas inconspícuas. Flores monoclinas, homostílicas, pedicelo 5-8 mm compr.; cálice 6 lobos iguais, 4-6 mm compr., lineares, glabro, pubérulos na base; corola alva, tubulosa-claviforme, tubo 15-18 mm compr., glabro externamente, internamente viloso na base, 6-mera, lobos 8-10 mm compr., triangular-lanceolado, ápice agudo ou arredondado, glabro; estames exsertos, inseridos na base do tubo, porção livre dos filetes 2-4,3 mm compr., anteras 1-1,5 mm compr., oblongas; estigma bífido, estiletes $16-18 \mathrm{~mm}$ compr. Fruto cápsula, deiscência septicida, 30-33 × 40-48 mm compr., oblonga, marrom na maturação, glabra; sementes 9-15 × 5-8 mm compr., oblongas, onduladas.

Distribuição: Está distribuída por toda a região neotropical, podendo ser encontrada no México, América Central e do Sul (Schumann 1888, Andersson 1992). No Brasil, ocorre em todas as regiões (Zappi 2012a).

Caracteriza-se por apresentar corola tubulosa-claviforme, levemente zigomorfa e frutos capsulares fortemente lenticelados. Foi encontrada associada a vegetação de campo rupestre em solo argiloso, a $780 \mathrm{~m}$ de altitude. Floresce na área, em dezembro e janeiro e frutifica em março.

Material examinado: BRASIL. BAHIA: Pindobaçu, Serra da Fumaça trilha para a Serra, Paredão de pedra, $10^{\circ} 39^{\prime} 57^{\prime \prime} \mathrm{S}$ e $40^{\circ}$ 22'08' W, 26/XII/2011, fl., L.A. Sousa 507 (HUNEB); 20/I/2012, fl., L.A. Sousa 518 (HUNEB); 17/III/2012, fr., L.A. Sousa 565 (HUNEB).

Material adicional examinado: BRASIL. BAHIA: Campo Formoso, Brejo do Tamanduá, Serra do Areão, 07/II/2006, fl., E.B. Souza 1453 (HUEFS); Jacobina, Caminho para Pingadeira, 069/ IV/1996, fl., M.L. Guedes 2876 (ALCB, HRB e HUEFS); Serra do Brite, 21/VII/1984, fl., fr., R.P. Orlandi \& H.P.Bautista 698 (ALCB, HRB); Miguel Calmon, entre a Faz. Pé de Serra e o riacho do Caldeirão, 05/IV/2001, fr., N.G. Jesus et al. 1280 (HRB, CEPEC); Saúde, Cachoeira do Paiaiá, 14/VI/1996, fl., fr., M.L. Guedes et al. 2897 (ALCB).

\section{Declieuxia aspalathoides Müll.Arg., Flora 59: 437.1876}

\section{Figura 4I-L}

Arbusto a subarbusto ereto, 1-1,5 m alt., monoico; caule cilíndrico, sem lenticelas, pubérulo no ápice, entrenós 5-10 mm compr. Estípulas persistentes, 1-1,5 × $1 \mathrm{~mm}$ compr., inteiras, lineares, pubérulas. Folhas pseudoverticiladas devido aos braquiblastos, coriáceas, sésseis; lâmina 4-7 × 0,5-1 mm, linear, base cuneada, ápice agudo, margem plana; ambas as faces hispidas; nervuras secundárias inconspícuas em ambas as faces. Inflorescências cimas, terminais e axilares, 3-12 flores, sésseis; 1-2 brácteas foliáceas, lanceoladas, bractéolas inconspícuas. Flores monoclinas, heterostílicas, pedicelos 0,3-5 mm compr., piloso; cálice 4 lobos, desiguais, 0,2-1,3 mm compr., lineares, glabros; corola azul-claro, infundibuliforme, tubo 3-4 mm compr., externamente glabro, anel de tricomas próximo da fauce, 4-mera, lobos oblongos, 1,5-2 mm compr., glabros a pubérulos; estames inseridos abaixo da fauce; anteras 0,8-1,2 mm compr., oblongas a subelípticas; estigma bífido, flores brevistilas, porção livre dos filetes 1,1,5 mm compr.; estilete 1,8-2,6 mm compr., flores longistilas, porção livre dos filetes $0,5-0,8 \mathrm{~mm}$ compr.; estilete
5-5,3 mm compr. Frutos esquizocárpicos, dicoca, 1,5-2 × 2,5-2,8 mm, lateralmente compressos, deiscência lateral, negro na maturação, glabro; sementes, 0,8-1 × 0,4 mm, marrons, com estrias circulares.

Distribuição: Espécie endêmica do Brasil, ocorrendo nos estados da Bahia, Distrito Federal, Minas Gerais e Sergipe, nos domínios da Caatinga e Cerrado (Kirkbride Junior 1976). Segundo Harley et al. (2005), esta é uma das três espécies típica dos campos rupestres da Chapada Diamantina. É também registrada para os campos de restinga na Bahia e Sergipe.

Caracteriza-se por apresentar folhas lineares densamente congestas nos ramos, sendo difícil observar a sua filotaxia, e por apresentar o caule suberoso, densamente ramificado no ápice. Foi encontrada na vegetação de transição entre floresta de encosta e campo rupestre, sobre solos arenosos, entre 890-930 m de altitude. Floresce e frutifica na área, em janeiro, fevereiro, junho e agosto.

Material examinado: BRASIL. BAHIA: Pindobaçu, Serra da Fumaça $10^{\circ} 40^{\prime} 03$ " S e 40²1'30" W, 29/VII/209, fl., fr., L.A. Sousa 319 (HUNEB); 26/VI/2011, fl., fr., L.A. Sousa 319 (HUNEB); 28/ VI/2011, fl., fr., L.A. Sousa 320 (HUNEB); 29/VI/2011, fl., fr., L.A. Sousa 328 (HUNEB); 20/I/2012, fl., fr., L.A. Sousa 521 (HUNEB); 20/II/2012, fl., fr., L.A. Sousa 550 (HUNEB).

11. Declieuxia fruticosa (Willd. ex Roem. \& Schult.) Kuntze, Revs. Gen. Pl. 1: 279. 1891.

Subarbusto, 0,7-0,8 m alt., monoico; caule cilíndrico, sem lenticelas, glabros, entrenós 20-50 mm compr. Estípulas persistentes, 2-3 $\times 2 \mathrm{~mm}$, inteiras, lineares, glabras. Folhas opostas, cartáceas, sésseis; lâmina 10-35 × 4-15 mm, oblanceolada a oblongo-elíptica, base atenuada, ápice agudo-acuminado, margem plana, glabras; venação broquidódroma, nervuras secundárias proeminentes na face abaxial, 5-8 pares. Inflorescências cimas, terminais e axilares, multifloras, pedúnculo 2-4,2 $\mathrm{mm}$ compr., glabro a pubérulo; 2 brácteas estreito-elípticas, bractéolas inconspícuas. Flores monoclinas, heterostílicas, pedicelo 0,1-0,6 mm compr., glabro; cálice 4 lobos iguais, 0,6-1 mm compr., oblongos, glabros; corola azul, infundibuliforme, tubo 3,8-4,5 mm compr., externamente glabro, piloso da porção mediana até a fauce, 4-mera, lobos 0,8-1,2 mm compr., ovados a oblongos, glabros; estames inseridos na porção mediana do tubo; anteras $0,6-0,8 \mathrm{~mm}$ compr., oblongas; estigma bífido; flores brevistilas, porção livre dos filetes 2,5-5 mm compr.; estilete 1,0-2,8 mm compr., flores longistilas, porção livre dos filetes 0,1-0,2 mm compr.; estilete 4-4,8 mm compr. Fruto esquizocarpo, didínamo, 3,5-4 × 2,5-3 mm, lateralmente compressos, deiscência lateral, azul a negro, glabro; sementes 2-3 $\times 2-4 \mathrm{~mm}$, marrons, planas, circulares, estrias circulares.

Distribuição: Está distribuída por toda a região neotropical (Kirkbride Junior 1976), sendo a espécie mais amplamente distribuída do gênero. No Brasil, ocorre em todas as regiões (Delprete 2010a).

Caracteriza-se por apresentar folhas oblanceoladas a oblongoelípticas, venação marcada na face inferior, marrom-escura após a secagem o que a difere de Declieuxia aspalathoides a segunda espécie ocorrente na área. Segundo Campos et al. (2006), apresenta grande variabilidade morfológica, principalmente quanto às folhas. Foi encontrada associada à floresta de encosta, sobre solo argiloso e em áreas sombreadas, com 600-720 m de altitude. Floresce e frutifica na área em junho e agosto.

Material examinado: BRASIL. BAHIA: Pindobaçu, Serra da Fumaça, 10 40'03" S e 40²1'30" W, 26/VI/2011, fl., fr., L.A. Sousa 338 (HUNEB); 26/VIII/2011, fr., L.A. Sousa 387 (UNEB); 10³9' $54,8^{\prime}$ 'S e 40 20' 51' W, 14/IV/2006, fl., V.J. Santos 529 (HUEFS).

Material adicional examinado: BRASIL. BAHIA: Catolés, encosta da Serra da Tromba, 14/IV/2000, fl., E.B.M. Silva 455 (HUEFS, HRB); Serra da Trompa, 14/VI/2000, fl., fr., E.B. Miranda Silva et al. 455 (ALCB); Jacobina, Monte Tabor, Hotel Serra do 
Ouro, 20/II/1993, fr., A.M.V. Carvalho et al. 4198 (CEPEC); Lençóis, Coqueiros, 11/VI/1988, fl., Cassia 82 (HBA).Pai Inácio, Cachoeira do Paiaiá, 14/VI/1996, fl., M.L. Guedes et al. 2897 (ALCB); Morro do Chapéu, 26/VIII/1980, fl., fr., R. Orlandi 275 (HRB); Morro do Chapéu, Cachoeira do Ferro Doido, 21/II/2006, fl., N. Roque 1321 (ALCB); Mucugê Unidade de Manejo Sustentável, 06/IV/1997, fl., H.P.Bautista \& S.L. Silva 314 (HRB); Saúde, Serra da Saúde, 03/ IX/1981, fl., L.M.C. Gonçalves 182 (HRB).

12. Diodella apiculata (Willd. ex Roem. \& Schult.) Delprete, Fl. Ilustr. Catarin. 1: 169-174. 2004.

Erva ereta ou prostrada, $20-70 \mathrm{~cm}$ alt., monoica; caule cilíndrico a tetrágono no ápice, sem lenticelas, levemente pubescente, entrenós 8-20 mm compr. Estípulas fimbriadas, persistentes, bainha 2-3 $\times$ 2-3,2 mm compr., 5-7 setas, desiguais, 4-12 mm compr., pilosas. Folhas opostas, membranáceas, sésseis; lâmina 4-11 × 2-4 mm, ovada a linear-lanceolada, base atenuada, ápice apiculado, margem plana; face adaxial escabra, abaxial glabra a pubérulo-escabrosa; venação eucamptódroma, nervuras secundárias visíveis em ambas as faces, 2-4 pares. Inflorescências glomérulos, axilares, raramente terminais, 2-8 por ramo florífero, 2-4-flores; 2 brácteas, lineares, glabras, 2 bractéolas, glabras. Flores monoclinas, homostílicas, sésseis; cálice 4 lobado, lobos iguais, 1-2 mm compr., estreito triangulares, glabro a pubérulos; corola lilás, infundibuliforme; tubo 4-10 mm compr., externamente pubérulo, internamente com anel de tricomas próximo da base, 4-mera, lobos 1-3 mm compr., triangulares, pilosos no ápice; estames exsertos, presos na fauce, porção livre dos filetes $0,5-2 \mathrm{~mm}$ compr., anteras 0,5-1 mm compr., oblongas; estigma capitado, estilete 5-10 mm compr. Fruto esquizocarpo, 2,5-3 $\times$ 2-3,5 mm, obovoide ou turbinado, 3-5 costado, sulco longitudinal na face dorsal, mericarpos indeiscentes, marrons na maturação, pubérulo a híspido, face ventral com duas depressões; sementes 0,6-1,8 × 1,2-1,5 mm, plano-convexas, elípticas ou obovadas, face ventral com depressão em forma de "Y".

Distribuição: Está distribuída na Américas Central e do Sul, Malásia e Ásia (Schumann 1888). No Brasil, ocorre em todas as regiões (Bacigalupo \& Cabral 2007b, Cabral \& Salas 2012b).

Caracteriza-se por apresentar folhas com ápice apiculado e lobos do cálice de comprimento iguais. Diferencia de Diodella teres por apresentar folhas com nervuras secundárias visíveis em ambas as faces, corola maiores (4-10 mm compr.) e através dos mericarpos com 3-5 costelas na face dorsal. Apresentou populações abundantes na área, encontrada nos campos rupestres em solo arenoso, e em florestas mais abertas em solo argiloso, entre 468-890 m de altitude. Floresce e frutifica na área em quase todos os meses do ano.

Material examinado: BRASIL. BAHIA: Pindobaçu, Serra da Fumaça. 10॰39' 59" S e 40²1' 59" W, 20/II/2012, fl., fr., L.A. Sousa 537 (HUNEB); 17/III/2012, fl., fr., L.A. Sousa 557 (HUNEB); 20/ II/2012, fl., fr., L.A. Sousa 559 (HUNEB), 10 39' 54,6”' S e 40²2' 20" W, 20/IV/2011, fl., fr., L.A. Sousa 71 (HUNEB); 27/V/2009, fl., fr., L.A. Sousa 101 (HUNEB); 27/V/2008, fl., fr., L.A. Sousa 104 (HUNEB); 26/X/2008, fl., fr., L.A. Sousa 149 (HUNEB); 18/VII/2009, fl., fr., L.A. Sousa 298 (HUNEB); 28/VI/2011, fl., fr., L.A. Sousa 327 (HUNEB); 29/XI/2011, fl., fr., L.A. Sousa 340 (HUNEB); 27/ VIII/2011, fl., fr., L.A. Sousa 413 (HUNEB); 29/IX/2011, fl., fr., L.A. Sousa 448 (HUNEB); 19/XI/2011, fl., fr., L.A. Sousa 472 (HUNEB); 19/XI/2011, fl., fr., L.A. Sousa 479 (HUNEB); 26/XII/2011, fl., fr., L.A. Sousa 500 (HUNEB); 29/IX/2011, fl., fr., L.A. Sousa 443 (HUNEB); 26/XII/2011, fl., fr., L.A. Sousa 2011 (HUNEB); 18/ III/2012, fl., fr., L.A. Sousa 578 (HUNEB); 19/V/2012, fl., fr., L.A. Sousa 594 (HUNEB).

13. Diodella radula (Willd. ex Roem. \& Schult.) Delprete, Fl. Ilustr. Catarin. Rubiáceas I: 174. 2004.
Erva ereta a decumbente, $40-60 \mathrm{~cm}$ alt., monoica; caule cilíndrico a tetrágono no ápice, sem lenticelas, hirsuto, entrenós 10-80 mm compr. Estípulas fimbriadas, persistentes, bainha 1,2-2 × 2,5-3,8 mm compr., pubescente, 7-10 setas, 1,4-3 mm compr., glabras. Folhas opostas, cartáceas, sésseis; lâmina 10-40 × 4-20 mm, largo-elíptica a oblongo-lanceolada, ápice agudo, base atenuada, margem plana; face adaxial escabrosa e abaxial hirsuta; venação eucamptódroma, nervuras secundárias conspícuas em ambas as faces, 3-4 pares. Inflorescências glomérulos, axilares, (3-)8-11 por ramo florífero, 2-4-flores; 2 brácteas foliáceas, lanceoladas, bractéolas inconspícuas. Flores monoclinas, homostílicas, sésseis; cálice 4 lobos desiguais, os maiores 2-3 mm compr., os menores 1,8-2,5 mm compr., estreitotriangulares, hirsutos; corola alva, infundibuliforme, tubo $4-5 \mathrm{~mm}$ compr., externamente piloso na porção superior, internamente com anel de tricomas na base do tubo, 4-mera, lobos 3,3-5 mm compr., triangulares, ciliados; estames exsertos, inseridos na fauce, porção livre dos filetes $0,8-1 \mathrm{~mm}$ compr., anteras 1,5-2 mm compr., longamente elíptica; estigma bilobado, estilete 6-8 $\mathrm{mm}$ compr. Fruto esquizocarpo, 2,5-3 × 2-3,8 mm, globoso, com sulco longitudinal, separando-se em dois mericarpos indeiscentes, 2-4 costelas, marrons na maturação, piloso apenas no ápice, face ventral lisa; sementes 1,2-2,6 × 0,8-2 mm, obovoides, castanhas, ápice fendido, sem sulcos na face ventral.

Distribuição: Distribui-se por toda a região neotropical (Andersson 1992, Delprete et al. 2004). No Brasil, ocorre em quase todas as regiões, exceto na Norte (Cabral \& Salas 2012b).

Distingue-se das demais espécies do gênero encontradas na área, por apresentar folhas com venação impressa na face superior e proeminente na face inferior, estípulas com setas glabras, lobos do cálice com 3,3-5 mm compr. e fruto piloso apenas no ápice. Foi encontrada sobre solos argilosos e arenosos, associada a áreas abertas e no interior da floresta a 470-860 $\mathrm{m}$ de altitude. Floresce e frutifica na área, nos meses de junho e julho.

Material examinado: BRASIL. BAHIA: Pindobaçu, Serra da Fumaça. $10^{\circ} 39^{\prime} 48^{\prime}$ ' S e $40^{\circ} 20^{\prime}$ 0,7' W, 26/VI/2011, fl., fr., L.A. Sousa 313 (HUNEB); 28/VII/2011, fl., fr., L.A. Sousa 318 (HUNEB); 23/VII/2011, fl., fr., L.A. Sousa 355 (HUNEB); 26/VIII/2011, fl., fr., L.A. Sousa 412 (HUNEB); 29/IX/2011, fl., fr., L.A. Sousa 433 (HUNEB); 15/XII/2011, fl., fr., L.A. Sousa 488 (HUNEB); 26/ XIII/2011, fl., fr., L.A. Sousa 509 (HUNEB); 19/XI/2011, fl., fr., L.A. Sousa 479 (HUNEB); 20/II/2012, fl., fr., L.A. Sousa 537 (HUNEB); 17/III/2012, fl., fr., L.A. Sousa 557 (HUNEB); 19/III/2012, fl., fr., L.A. Sousa 558 (HUNEB).

14. Diodella teres (Walter) Small, Fl. Lancaster Co. 271. 1913.

Erva decumbente, $20-40 \mathrm{~cm}$ alt., monoica; caule cilíndrico a tetragonal, sem lenticelas, pubérulo a piloso, entrenós 10-35 mm compr. Estípulas fimbriadas, persistentes, bainha 1-1,5 × 2,8-3,5 mm, pubérula, margem pilosa, 8-10 setas, 4-6 mm compr., pilosas. Folhas opostas, cartáceas, sésseis; lâmina $8-22 \times 2-5 \mathrm{~mm}$, lanceolada a oblongo-lanceolada, base atenuada, ápice agudo a acuminado, margem plana; ambas as faces estrigosas a tomentosas; venação eucamptódroma, nervuras secundárias inconspícuas em ambas as faces, 3-4 pares. Inflorescências fascículos, axilares, 2-4 floro; 2 brácteas foliáceas, bractéolas inconspícuas. Flores monoclinas, homostílicas, sésseis; cálice 1,5-2 mm compr., 4 lobos desiguais, os maiores 1,3-2 mm compr., os menores 1-1,5 mm compr., lanceolados, margem hirsuta; corola branca a lilás, infundibuliforme, tubo 3,5-4,8 mm compr., 4-mera, lobos 1,5-2 mm compr., triangulares, externamente pubérulos, internamente com anel de tricomas na porção inferior; estames exsertos presos na fouce, porção livre dos filetes $0,6-0,8 \mathrm{~mm}$ compr., anteras $0,5-0,8 \mathrm{~mm}$ compr., oblongas; estigma bilobado, estilete $3,5-4,5 \mathrm{~mm}$ compr. Fruto esquizocarpo, 4-4,5 × 3,5-4 mm, globoso a subovoide, com sulco longitudinal, 


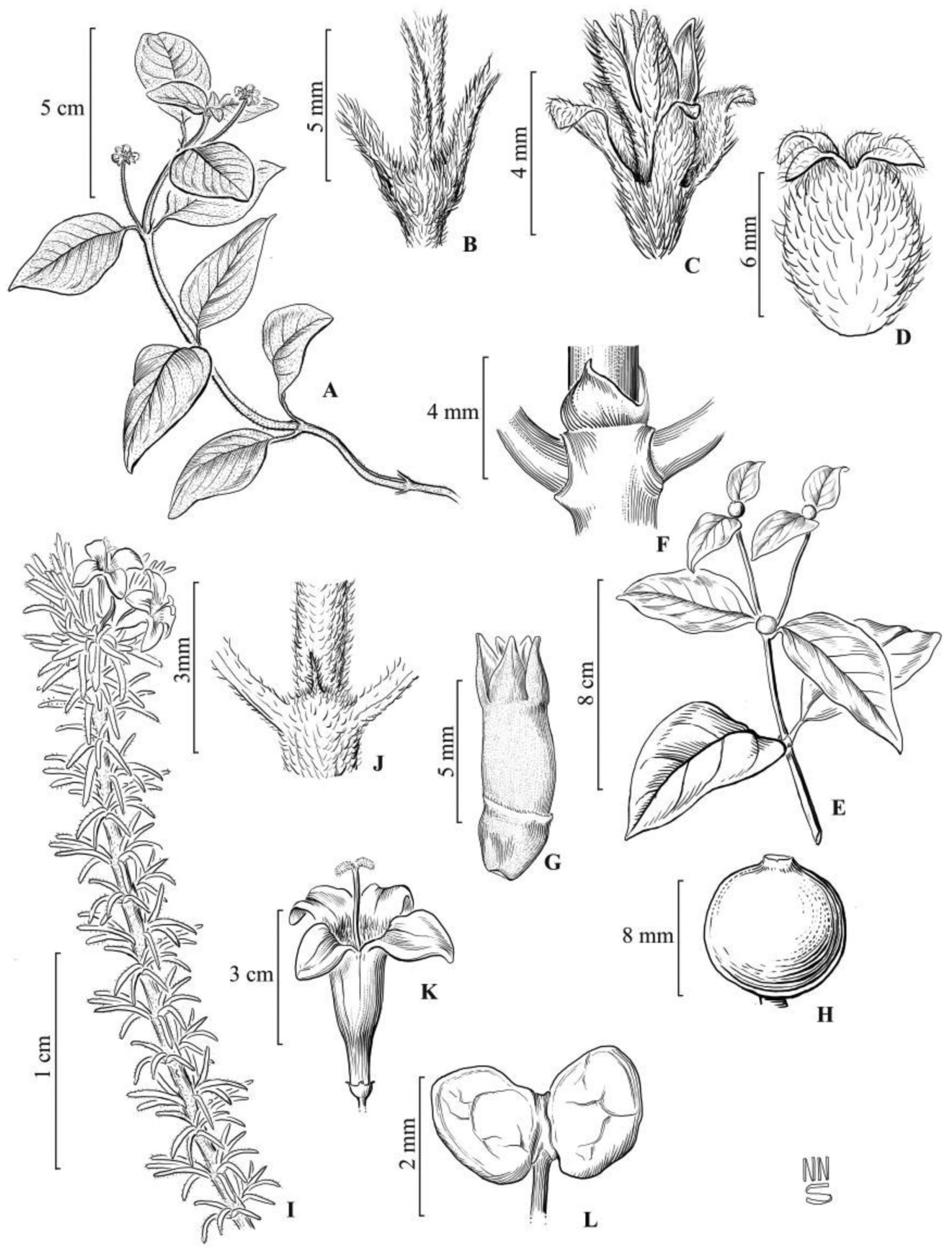

Figura 4. A-D. Coccocypselum lanceolatum - A. ramo florífero; B. estípula; C. flor e hipanto; D. fruto. E-H. Cordiera elliptica - E. ramo frutífero; F. estípula; G. flor masculina; H. fruto. I-L. Declieuxia aspalathoides - I. ramo florífero; J. estípula; K. flor; L. fruto. (A-D. L.A. Sousa 468; E-H. L.A. Sousa 452; I-L. L.A. Sousa 328).

Figure 4. A-D. Coccocypselum lanceolatum - A. flowering branch; B. stipule; C. flower and hypanthium; D. fruit. E-H. Cordiera elliptica - E. fruitful branch; F. stipule; G. male flower; H. fruit. I-L. Declieuxia aspalathoides - I. flowering branch; J. stipule; K. flower; L. fruit. (A-D. L.A. Sousa 468; E-H. L.A. Sousa 452; I-L. L.A. Sousa 328). 
separando-se em dois mericarpos indeiscentes, 1(3) costelas, marrons na maturação, pubescentes, face ventral com duas depressões; sementes 2,5-3 × 1,5-2 mm, obovoides, plano-convexas, castanhas, sulco longitudinal na face ventral em forma de "Y".

Distribuição: Distribuída na região neotropical, ocorrendo no Sudeste dos Estados Unidos, América Central e América do Sul (Cabral \& Bacigalupo 2005, Campos et al. 2006). No Brasil, ocorre em todas as regiões (Cabral \& Salas 2012b).

Caracteriza-se por apresentar folhas com nervuras secundárias inconspícuas e frutos com sulco longitudinal na face ventral. Diferencia-se de Diodella apiculata por apresentar cálice com lobos desiguais e face dorsal dos mericarpos 1-(3) costelas (vs 3-5). Foi encontrada assciada à vegetação aberta, na Caatinga perturbada, sobre solo argiloso a $470 \mathrm{~m}$ de altitude. Floresce e frutifica na área em junho e julho.

Material examinado: BRASIL. BAHIA: Pindobaçu, Serra da Fumaça. 10³9' 59' S e 40²1' 59' W, 26/VI/2011, fr., L.A. Sousa 369 (HUNEB); 28/VII/2012, fl., fr., L.A. Sousa 599 (HUNEB).

15. Emmeorhiza umbellata (Spreng.) K. Schum., Fl. Bras. 6(6): 408. 1889.

Liana, monoica; caule herbáceo, cilíndrico a tetragonal no ápice, sem lenticelas, glabros, entrenós 35-110 mm compr. Estípulas fimbriadas, persistentes, bainha 3-8 × 2-3 mm, glabra, 7 setas desiguais, menores nas extremidades, 1,5-7 mm compr., glabras. Folhas opostas, cartáceas, pecíolo 3-8 mm compr.; lâmina 30-95 × 15-40 mm, elíptica a largo-lanceolada, base cuneada, ápice acuminado, margem plana; ambas as faces glabras; venação eucamptódroma, nervuras secundárias proeminentes a plicadas, visíveis em ambas as faces, 4-5 pares. Inflorescências umbeliformes, terminais, multifloras, sésseis a pedunculadas $0,5-1,5 \mathrm{~mm}$ compr., 2 brácteas foliáceas, lanceoladas, 2 bractéolas, lanceoladas. Flores monoclinas, homostílicas, cálice 4 lobos iguais, 1-1,2 mm compr., ovado-triangulares, hirsutos; corola alva, infundibuliformes, tubo 2-2,5 mm compr., externamente hirsuto, anel de tricomas na inserção dos filetes, 4-mera, lobos 1-1,5 mm compr., ovados, pubérulos; estames exsertos inseridos na fauce da corola, porção livre dos filetes $0,3-7 \mathrm{~mm}$ compr., anteras $0,5-0,8 \mathrm{~mm}$ compr., oblongas; estigma bífido, estilete 1,8-2,2 mm compr. Fruto cápsula septicida, 2-3 × 1-1,5 mm, obovoide, castanho na maturação, glabro; sementes 2-3 mm comp., elipsoides, testa rugosa.

Distribuição: Ocorre exclusivamente na América do Sul, na ilha de Trinidad, Colômbia, Venezuela, Guianas, Peru, Bolívia, Brasil e Paraguai (Bacigalupo \& Cabral 2007c). No Brasil, ocorre em todas as regiões (Delprete 2010a, Cabral \& Salas 2012c).

Caracteriza-se por apresentar hábito trepador com caule volúvel, folhas com nervuras secundárias proeminentes em ambas as faces a plicadas e através das inflorescências umbeliformes. Foi encontrada nas bordas e no interior de áreas florestadas, em solos argilosos com serapilheira, a $890 \mathrm{~m}$ de altitude. Foi encontrada na área com flores apenas no mês de junho.

Material examinado: BRASIL. BAHIA: Pindobaçu, Serra da Fumaça. $10^{\circ} 39^{\prime} 54,6$ "' S e $40^{\circ} 22^{\prime} 20^{\prime \prime} \mathrm{W}, 29 / \mathrm{VII} / 2011$, fl., L.A. Sousa 330 (HUNEB).

Material adicional examinado: BRASIL. BAHIA: Jacobina, Serra do Tombador, 14/X/2001, fl., H.P. Bautista 981 (CEPEC); Lençóis, Rio Lençóis, 09/I/1992, fl., L.S. Funch et al. 44 (ALCB); Morro do Chapéu, 26/VIII/1980, fl., H.P. Bautista 378 (HRB); Ventura, 27/VIII/1981, fl., J.D.C.A. Ferreira 38 (HRB); 26/VIII/1980, fl., E.B.M Silva 455 (HUEFS, HRB); Rio de Contas, Pico das Almas. $13^{\circ} 32^{\prime} \mathrm{S}$ e $41^{\circ} 53^{\prime} \mathrm{W}, 06 / \mathrm{XI} / 1988$, fr., R.M. Harley et al. 25957 (CEPEC); Rio Brumado, $13 \mathrm{~km}$ da cidade; $13^{\circ} 28^{\prime} \mathrm{S}$ e $41^{\circ} 52^{\prime} \mathrm{W}$, 27/X/1988, fr., R.M. Harley et al. 25701 (CEPEC).

16. Genipa americana L., Syst. Nat. 2: 931. 1759.
Árvore, 5-7 m alt., dioica ou monoica; caule cilíndrico, sem lenticelas, glabro, entrenós 20-30 mm compr. Estípulas decíduas, $15-20 \times 6-8 \mathrm{~mm}$, inteiras, triangulares, ápice acuminado, glabras. Folhas opostas, congestas no ápice, pecíolo 10-15 mm, pubescente; lâmina 220-250 × 85-120 mm, oblanceolada a lanceolada, ápice obtuso, base atenuada, margem plana; glabras a pubescentes em ambas as faces, venação broquidódroma, nervuras secundárias proeminentes na face abaxial, 10-15 pares. Inflorescências cimeiras, terminais ou axilares, (1-)3-8-flores, pedúnculo 5-15 mm compr.; 2 brácteas ovadas a lanceoladas, bractéolas inconspícuas. Flores monoclinas ou raramente diclinas, homostílicas, pediceladas, cálice truncado, tubo 7-8 mm compr., 5-6 lobos inconspícuos; corola hipocrateriforme, branca ou amarela; tubo 10-40 mm compr., externamente pubescente, anel de tricomas próximo da fauce, 5-6-mera, lobos 20-60 mm compr; elípticos, seríceos; estames inseridos na fauce; sésseis; anteras 5-18 mm compr., lanceoladas; estigma espatulado, bífido, estilete 25-30 mm compr. Fruto baga, 60-100 × 40-80 mm, subglobosa, cálice persistente, marrom acinzentada, pilosa; sementes $8-10 \times 6-5 \mathrm{~mm}$ compr., arredondadas, comprimidas lateralmente, lisas.

Distribuição: Está distribuída na Flórida, México, América Central e América do Sul (Dwyer 1980). No Brasil, ocorre em quase todo o território nacional, tanto natural como cultivada (Andersson 1992).

Genipa americana é marcadamente distinta das demais espécies presentes na área e se caracteriza por apresentar as folhas concentradas no ápice, frutos marrom-acinzentados e mais desenvolvidos (60-100 × 40-80 mm diâm.) em relação às demais espécies. Foi encontrado apenas alguns indivíduos nas margens do rio Fumaça em áreas florestadas a $480 \mathrm{~m}$ de altitude, sobre solo argiloso. Frutifica na área nos meses de março e junho.

Material examinado: BRASIL. BAHIA: Pindobaçu, Serra da Fumaça. $10^{\circ} 39$ ' 59" S e 40²1' 59" W, 18/IV/2012, fr., L.A. Sousa 585 (HUNEB); 20/V/2012, fr., L.A. Sousa 590 (HUNEB).

Material adicional examinado: BRASIL. BAHIA: Andaraí, rio Paraguaçu, 20/IV/2001, fr., D.M. Loureiro 46 (ALCB); Entre Rios, 10/I/2011, fl., M.B.B. Alves \& P.B. Alves 14 (ALCB); Miguel Calmon, parque das Sete Passagens, 23/XII/2006, fr., M.L. Guedes 13206 (ALCB); Senhor do Bonfim, Povoado de Estiva, Serra de Santana, 13/VI/2005, fl., D. Cardoso et al. 719 (HUEFS).

17. Guettarda sericea Müll.Arg., Flora 58: 450. 1875.

Figura 5A-C

Arbusto, 1,8-2,2 m alt., ramos apoiantes, monoica; caule cilíndrico, geralmente espinescente, lenticelados, glabros a pubérulos no ápice, entrenós 50-120 mm compr. Estípulas persistentes apenas no ápice, 2,8-6 × 0,8-4,5 mm, inteiras, triangulares, ápice agudo, densamente adpresso-pubescente. Folhas opostas, cartáceas, pecíolo, 0,5-12 mm compr., tomentoso; lâmina 15-80 × 8-45 mm, largo-elíptica, ovada a oblanceolada, base aguda a obtusa, ápice agudo, margem plana; face adaxial pilosa, abaxial velutina; venação broquidódroma, nervuras secundárias proeminentes na face abaxial, 6-8 pares. Inflorescências escorpioides, axilar ou terminal, 8-12-flores, pedúnculo 10-20 mm compr., adpresso-pubescente ou esparso a denso-hirsuto; 2 brácteas foliáceas, lanceoladas, bractéolas lanceoladas, pubescentes. Flores monoclinas, heterostílicas, sésseis; cálice truncado sublobado, tubo 2-3,5 mm compr., adpresso-pubescente; corola rosa, hipocrateriforme, tubo cilíndrico 10-11 mm compr., externamente seríceo, internamente glabro, 6-mera, lobos 4-8 mm compr., triangulares, oblongos, ápice arredondado, pilosos; estames inseridos próximos da fouce, sésseis; anteras 2-2,2 mm compr., estreito-oblongas; estigma globoso, flores brevistilas, porção livre dos filetes $0,5-0,7 \mathrm{~mm}$ compr.; estiletes 7-9 mm compr., flores longistilas, porção livre dos filetes $2-2,5 \mathrm{~mm}$ compr.; estiletes 14-16 mm compr. Fruto drupa, 11-15 × 7-11 mm, 
globosa a oblonga-elipsoide, vermelha a negra na maturação, 3-4 pirenos, rugosa, lenhosa; sementes 1,2 × $1 \mathrm{~mm}$, cilíndricas.

Distribuição: Espécie endêmica do Brasil. Ocorre apenas na região Nordeste nos estados da Bahia ao Ceará, exceto em Sergipe, no domínio da Caatinga (Barbosa 2012a).

Caracteriza-se por apresentar caule geralmente apoiante, nigrescente, geralmente lenticelados e com ramos curtos espinescentes, e frutos elipsoides, negros após a maturação. Foi encontrada associada à vegetação aberta de Caatinga perturbada, sobre solo argiloso a $480 \mathrm{~m}$ de altitude. Floresce na área em julho, agosto, novembro, dezembro e frutifica em janeiro e fevereiro.

Material examinado: BRASIL. BAHIA: Pindobaçu, Serra da Fumaça. $10^{\circ} 39^{\prime} 53,6$ " S e $40^{\circ} 22^{\prime} 20^{\prime \prime} \mathrm{W}, 26 / \mathrm{VII} / 2011$, fl., L.A. Sousa 31 (HUNEB); 29/VIII/2011, fl., L.A. Sousa 431 (HUNEB); 26/VIII/2011, fl., L.A. Sousa 371 (HUNEB); 19/XI/2011, fl., L.A. Sousa 480 (HUNEB); 26/XII/2011, fl., L.A. Sousa 510 (HUNEB); 20/I/2012, fr., L.A. Sousa 514 (HUNEB); 20/II/2012, fr., L.A. Sousa 552 (HUNEB).

18. Malanea macrophylla Bartl. ex Griseb., Fl. Brit. W. Ind. 337. 1861.

Figura 5D-F

Liana, 1-2,5 m alt., monoico; caule lenhoso, cilíndrico, lenticelado, glabro a hirsuto, entrenós 60-130 mm compr. Estípulas decíduas, 7-15 × 5-10 mm, inteiras, ovadas, ápice arredondado, glabras. Folhas opostas, cartáceas, pecíolos 0,7-1,5 mm compr., glabros a esparso pubérulos; lâmina 40-135 × 20-65 mm, ovada, oblongo-ovada, largo-elíptica, base aguda a obtusa, ápice agudo a obtuso, margem plana; face adaxial glabra a hirsuta em ambas as faces; venação, broquidódroma, nervuras secundárias proeminentes em ambas as faces, 6-8 pares. Inflorescência panícula, axilar, multifloras, pedúnculo 5-15 mm compr., pubérulo; 2 brácteas ovado-triangulares, bractéolas inconspícuas. Flores monoclinas, homostílicas, sésseis; cálice 5 lobos diferentes $05-08 \mathrm{~mm}$ compr., triangulares, tubo pubescente; corola branco-amarelada, infundibuliforme, tubo $2-4 \mathrm{~mm}$ compr., externamente seríceo, anel de tricomas próximos da fauce, 4-5-mera, lobos 1,5-2 mm compr., triangulares, densamente piloso na face interna; estames inseridos próximos da fouce, porção livre dos filetes 02-04 mm compr.; anteras 0,8-1 mm compr., elípticas; estigma bífido, estilete 2-3 mm compr., incluso. Fruto drupa, $8-11 \times 3 \mathrm{~mm}$, oblongo-elipsoide, atropurpúreo na maturação, glabro; sementes 2 3-4 × 1-2 mm, elipsoides, com sulco longitudinal.

Distribuição: Amplamente distribuída, desde a América Central até a Venezuela, Suriname, Guiana Francesa, Colômbia, Bolívia e Brasil (Taylor et al. 2004). No Brasil, ocorre em todas as regiões, nos domínios da Amazônia, Cerrado e Mata Atlântica (Barbosa 2012b).

Caracteriza-se por apresentar hábito trepador, geralmente com raízes adventícias, frutos drupas oblongo-elipsoides, atropurpúreos na maturação. Foi encontrada associada à floresta de encosta em bom estado de conservação, sobre solo argiloso, entre 640-700 m de altitude. Frutifica na área em novembro, dezembro e março.

Material examinado: BRASIL. BAHIA: Pindobaçu, Serra da Fumaça, $10^{\circ} 40^{\prime} 03$ " S e 40²1'30" W, 19/XII/2011, fr., L.A. Sousa 481 (HUNEB); 26/XII/2011, fr., L.A. Sousa 497 (HUNEB); 26/XII/2011, fr., L.A. Sousa 505 (HUNEB); 17/III/2011, fr., L.A. Sousa 564 (HUNEB).

Material adicional examinado: BRASIL. BAHIA: Lençóis, Morro do Pai Inácio, 04/II/1995, fl., fr., A.M.Giulietti 1531 (ALCB, HRB); 12/III/1997, fl., fr., P. Gasson 6193 (ALCB, HRB); Serra da Chapadinha, ao logo do Córrego, 06/II/1995, fl., fr., A.M.Giulietti \& L.Funch 1614 (CEPEC, HUEFS, ALCB).

19. Manettia cordifolia Mart., Denkschr. Königl. Akad. Wiss. München 9: 95, t. 7. 1824.
Liana, monoica; caule herbáceo, cilíndrico, sem lenticelas, glabro a pubérulo no ápice, entrenós $13-18 \mathrm{~cm}$ compr. Estípulas persistentes, 1,5-3 × 2-3 mm compr., inteiras, triangulares, ápice agudo a curtamente acuminado, glabras a pubescentes na margem. Folhas opostas, cartáceas, pecíolos 0,5-1 mm compr., tomentosos; lâmina 15-100 × 6-40 mm, oval-lanceolada a oblonga, base atenuada a acuminada, ápice agudo a acuminado, margem plana; face adaxial glabra a pubérula, face abaxial glabra; venação eucamptódroma, nervuras secundárias proeminentes na face abaxial, 3-5 pares. Inflorescências cimeiras, axilares, 1-flores, pedúnculos 6-40 mm compr., glabros; 2 brácteas foliáceas, lanceoladas, velutinas, bractéolas inconspícuas. Flores monoclinas, homostílicas, pedicelo 8-35 mm compr., glabro a pubescente; cálice 4 lobos, 2-5 mm compr., estreito-triangulares a subulados, pubescentes; corola vermelha, tubulosa-claviforme, tubo 20-38 mm compr., externamente glabro, internamente com um anel de tricomas próximo da base, 4-mera, lobos 2-4 mm compr., ovado-triangulares, pubérulos; estames exsertos, inseridos na fauce da corola, porção livre dos filetes 1,5-2,0 mm compr., anteras oblongas, 0,6-0,8 mm compr.; estigma bífido, estilete 20-38 mm compr. Fruto cápsula, 10-16 × 6-10 mm, oblonga, deiscência longitudinal, marrom na maturação, glabra; sementes oblongas, 2,8-3 mm compr., castanhas, aladas.

Distribuição: Distribui-se no México, América Central, Colômbia, Bolívia, Brasil e Norte da Argentina (Delprete \& Cortés-B 2006). No Brasil, ocorre em todas as regiões (Pessoa \& Macias 2012).

Caracteriza-se pelo conjunto de caracteres como hábito trepador com caule volúvel, inflorescências unifloras com brácteas foliáceas geralmente cordiforme, e pela corola vermelha. Foi encontrada associada a bordas da floresta de galeria, sobre solo argiloso a $470 \mathrm{~m}$ altitude. Floresce na área em julho, agosto e frutifica em agosto.

Material examinado: BRASIL. BAHIA: Pindobaçu, Serra da Fumaça. $10^{\circ} 39$ ' 59' S e 40²1' 59' W, 28/VI/2011, fl., L.A. Sousa 339 (HUNEB); 28/VIII/2011, fl., L.A. Sousa 357 (HUNEB); $10^{\circ}$ 39' 53,6" S e 40²2' 20" W, 26/VII/2011, fl., fr., L.A. Sousa 373 (HUNEB); $10^{\circ} 40^{\prime} 01,6$ " ' S e $40^{\circ} 21^{\prime} 21$ ' W, 28/VII/2012, fl., fr. $L . A$. Sousa 613 (HUNEB).

20. Mitracarpus baturitensis Sucre, Rodriguésia 26(38): 255. 1971.

Erva ereta, 35-40 cm alt., monoica; caule cilíndrico a tetragonal, sem lenticelas, piloso, ou densamente híspido, entrenós 30-60 mm compr. Estípulas fimbriadas, persistentes, bainha estipular 1,2-1,8 $\times$ 2-3 mm, ciliadas, 4-7 setas, 1-3 mm compr., densamente ciliadas. Folhas opostas, herbáceas, sésseis; lâminas 15-30 ×5-8 mm, estreito-elíptica, ápice agudo, base aguda, margem plana; face adaxial escabra, abaxial glabra, pubescente na nervura principal; venação eucamptódroma, nervuras secundárias inconspícuas em ambas as faces, 2-3 pares. Inflorescências, glomérulos axilares e terminais, 1-2 por ramo florífero, multifloros; 2-4 brácteas foliáceas, bractéolas inconspícuas. Flores monoclinas, homostílicas, pedicelos $0,5-0,8 \mathrm{~mm}$ compr., pilosos; cálice 4-lobos, desiguais, dois maiores, 1,5-2 mm compr., dois menores, 0,8-1 mm compr., lanceolados, densamente ciliados; corola branca, hipocrateriforme, tubo 1,2-1,5 mm compr., externamente glabro, anel de tricomas moniliformes na metade interna; lobos 0,8-1 mm compr., ovados, ciliados na face externa; estames inseridos na fauce, sésseis a subsésseis, porção livre do filete 0,3-0,7 mm compr., anteras $0,6 \times 0,8 \mathrm{~mm}$ compr., oblongas; estigma bífido, 1,8-2 mm compr., excerto. Fruto cápsula 1-1,5 × 0,8-1,2 mm compr., globosa, com deiscência transversal, marrom na maturação, pilosa no ápice; sementes $0,6-0,8 \times 0,5-0,7 \mathrm{~mm}$, globosas, castanhas, face dorsal com depressão cruciforme impressa, exotesta fovéoloreticulada, face ventral com encaixe em forma de " $X$ ".

Distribuição: Espécie endêmica do Brasil ocorrendo apenas nas regiões Nordeste (BA, CE, PB, PE e PI) e Centro-Oeste (GO, MT), 
nos domínios da Caatinga e do Cerrado (Souza et al. 2010, Souza 2012).

Caracteriza-se por apresentar folhas opostas cruzadas, sem braquiblastos e através do tubo da corola externamente glabro. Diferencia-se de Mitracarpus frigidus por apresentar o caule cilíndrico, sem alas $v s$ caule tetragonal, alado, e de M. salzmannianus devido às flores menores (tubo 1,2-1,5 $\mathrm{mm} v s$ 3,5-4,8 mm compr.), e por apresentar sementes com depressão cruciforme ventral em forma "X" ( $v s$ "Y"). Foi encontrada em áreas de campo rupestre sobre afloramento rochoso, a $703 \mathrm{~m}$ de altitude. Floresce e frutifica na área no mês de agosto.

Material examinado: BRASIL. BAHIA: Pindobaçu, Serra da Fumaça. $10^{\circ} 39^{\prime}$ 59" S e 40²1' 53" W, 26/VIII/2011, fl., fr., L.A. Sousa 390 (HUNEB).

Material adicional examinado: BRASIL. BAHIA: Jacobina, Serra do Tombador, 28/X/1995, fl., A.M.A. Amorim et al. 1798 (CEPEC); 02/VII/1996, fl., A.M. Giulietti et al. 3316 (ALCB); Morro do Chapéu, subida da Serra para Morro do Chapéu, 25/VIII/1981, fl., R. Orlandi 444 (HRB); Mucugê, estrada para Abaíra, 14/VI/2010, fl., M.L. Guedes et al. 171781 (ALCB); Lençóis, Pai Inácio, 04/ VII/1994, fl., M.C. Ferreira 16 (HRB); Juazeiro, 08/II/1970, fl., A.L. Costa (ALCB). Rio de Contas, Pico das Almas, estrada para torre de repetição, 29/VII/1994, fl., A. Pereira et al. 246 (HRB); Senhor do Bonfim, Carrapichel, 29/V/2005, fl., P.D. Carvalho et al. 200 (HUEFS).

21. Mitracarpus frigidus (Willd. ex Roem. \& Schult.) K.Schum., Fl. Bras. 6(6): 81. 1888

Figura 5G-J

Erva ou subarbusto, $40-60 \mathrm{~cm}$ alt.; caule fortemente tetrágono, alado, sem lenticelas, glabro ou pubérulos, entrenós 40-110 mm compr. Estípulas fimbriadas, persistentes, bainha estipular, 1,2-2,2 $\times$ 1,8-2 mm compr., pubérula, 5-7 setas, 2-5 mm compr., glabras. Folhas pseudoverticiladas devido aos braquiblastos, cartáceas, sésseis; lâmina 7-60 × 2-12 mm, longo-elíptica, oblanceolada a oblonga, base atenuada ou cuneada, ápice agudo, margem plana; ambas as faces escabras a estrigosas; venação eucamptódroma, nervuras proeminentes em ambas as faces, 3-4 pares. Inflorescências glomérulos terminais e axilares, 1-3 por ramo florífero, multifloras; 2-4 brácteas foliáceas, bractéolas inconspícuas. Flores monoclinas, homostílicas, sésseis; cálice 4 lobos desiguais, dois maiores, 3,5-4 mm compr., dois menores, 1,2-1,5 mm compr., linear-lanceolados, margens hirsutas; corola alva, hipocrateriforme, tubo 3-3,5 mm compr., externamente pubérulo-papilosa, internamente com anel de tricomas próximo da base; 4-mera, lobos 1,1-1,5 mm compr., ovados, pubérulos; estames subinclusos, inseridos na fauce da corola, porção livre dos filetes $0,3-0,6 \mathrm{~mm}$ compr.; anteras lineares 1-1,1 mm compr.; estigma bífido, estilete 3,5-4 mm compr. Fruto cápsula 1,8-2 × 1-1,5 mm, obcônica, com deiscência transversal, marrom na maturação, glabra ou pubérula no ápice; sementes 1-1,2 $\times$ 0,6-0,8 mm, globosas, castanhas, face dorsal com depressão cruciforme profundamente impressa, exotesta foveolo-reticulada, face ventral com encaixe em forma de "X".

Distribuição: Distribui-se na Colômbia, Venezuela, Guiana Francesa e Brasil. No Brasil, ocorre em todas as regiões, exceto no Centro-Oeste (Delprete et al. 2004, Souza et al. 2010).

Diferencia-se das demais, por apresentar caule alado e sementes com depressão cruciforme dorsal profundamente impressa. Foi encontrada em áreas de Caatinga perturbada, aberta, sobre solo argiloso na base da serra a 450m. Floresce e frutifica na área no mês de outubro.

Material examinado: BRASIL. BAHIA: Pindobaçu, Serra da Fumaça. $10^{\circ} 39^{\prime}$ 56,7' S e 40²0' 54,6” W, 18/XI/2011, fl., fr. L.A. Sousa 460 (HUNEB).
22. Mitracarpus salzmannianus DC., Prodr. 4: 571.1830.

Erva ou subarbusto ereto ascendente ou decumbente, $20-50 \mathrm{~cm}$ alt., monoica; caule tetragonal, sem lenticelas, escabro ou hispido, entrenós 18-150 mm compr. Estípulas fimbriadas, persistentes, bainha 1,5-3,8 × 1,5-4 mm, pubescente, 4-8 setas, 1-6 mm compr., glabras. Folhas pseudoverticiladas devido aos braquiblastos nas axilas, cartáceas, sésseis; lâmina (4)17-45 × (2)4-10 mm, elíptica, estreito-elíptica a lanceolada, base atenuada, ápice agudo-mucronado, margem plana; ambas as faces escabras ou densamente estrigosa; venação eucamptódroma, nervuras secundárias proeminentes na face abaxial, ou as vezes inconspícuas, 2-3(5) pares. Inflorescências em glomérulos, terminais e axilares, 2-4(5) por ramo florífero, multifloros; 2-4 brácteas foliáceas, bractéolas inconspícuas. Flores monoclinas, homostílicas; pedicelos 0,4-1 mm compr., glabros; cálice 4 lobos desiguais, dois maiores, 2,8-3,2 mm compr., dois menores, 1,2-2 mm compr., lanceolados, margem hirsuta; corola alva, hipocrateriforme, tubo 3,5-4,8 mm compr., externamente piloso na metade superior, anel de tricomas na porção mediana do tubo, 4-mera, lobos 1-1,2 mm compr., triangulares, pilosos externamente; estames subinclusos, inseridos na fauce, porção livre dos filetes 0,4 mm compr., anteras 0,6-0,8 mm compr., oblongas; estigma bífido, estilete 4,5-6 mm compr. Fruto cápsula 1,8-3 × $3 \mathrm{~mm}$ compr., ovoide, com deiscência transversal, marrom-escura na maturação, glabra; sementes 0,7-1,1 × 0,4-0,6 mm, oblongas, castanhas, face dorsal sem depressão, exotesta foveolo-reticulada, face ventral com encaixe em forma de "Y invertido"

Distribuição: Espécie amplamente distribuída, ocorrendo nas Guianas, Suriname e Brasil. No Brasil, ocorre nas regiões Norte (PA), Centro-Oeste (GO), Sudeste (ES, MG e RJ), e em todo o Nordeste (Souza et al. 2010), nos domínios da Amazônia, Caatinga e Cerrado (Souza 2012).

Diferencia-se das demais espécies do gênero principalmente pelas características reprodutivas, como corola externamente pilosa na metade superior, semente com face dorsal sem depressão e face ventral com encaixe em forma de "Y invertido". Segundo Souza et al. (2010) esta espécie apresenta ampla variação morfológica, principalmente quanto aos caracteres vegetativos. Foi encontrada em diferentes fitofisionomias associada à vegetação aberta, em solos arenosos e argilosos, entre 450-890 m de altitude. Floresce e frutifica na área de estudo em quase todos os meses do ano, porém não foi observada nos meses secos.

Material examinado: BRASIL. BAHIA: Pindobaçu, Serra da Fumaça. $10^{\circ} 39^{\prime} 53,6^{\prime \prime} \mathrm{S}$ e $40^{\circ} 20^{\prime} 47^{\prime \prime} \mathrm{W}, 26 / \mathrm{VII} / 2011$, fl., fr., L.A. Sousa 359 (HUNEB); 23/VI/2011, fl., fr., L.A. Sousa 384 (HUNEB); 26/VII/2011, fl., fr., L.A. Sousa 397 (HUNEB); 29/IX/2011, fl., fr., L.A. Sousa 426 (HUNEB); 26/VII/2011, fl., fr., L.A. Sousa 435 (HUNEB); $10^{\circ} 39 ' 53,6^{\prime}$ ' S e 40²2' 20" W, 29/XII/2009, fl., fr., L.A. Sousa 144 (HUNEB); 26/VII/2011, fl., fr., L.A. Sousa 415 (HUNEB); 26/VIII/2011, fl., fr., L.A. Sousa 417 (HUNEB); 29/IX/2011, fl., fr., L.A. Sousa 474 (HUNEB); 19/XI/2011, fl., fr., L.A. Sousa 474 (HUNEB); 19/XI/2011, fl., fr., L.A. Sousa 475 (HUNEB); 19/XI/2011, fl., fr., L.A. Sousa 485 (HUNEB); 29/IX/2011, fl., fr., L.A. Sousa 445 (HUNEB); 26/XII/2011, fl., fr., L.A. Sousa 499, (HUNEB).

23. Palicourea guianensis Aubl., Hist. P1. Guiane 1: 173, t. 66. 1775 .

Figura 6A-D

Arbusto, 1,8-2,5 m alt., monoico; caule cilíndrico, sem lenticelas, glabro, entrenós 10-60 mm compr. Estípulas persistentes, inteiras, 3-5 × 2-4 mm compr., bífidas, concrescidas na base, lobos triangulares, ápices obtusos ou agudos, glabras. Folhas opostas, cruzadas, cartáceas a papiráceas, pecíolos 10-30 mm compr.; lâmina (65)120-180 × (25)40-80 mm, ovada-elíptica, lanceolada, oblanceolada, base aguda ou subobtusa, ápice agudo a acuminado, 


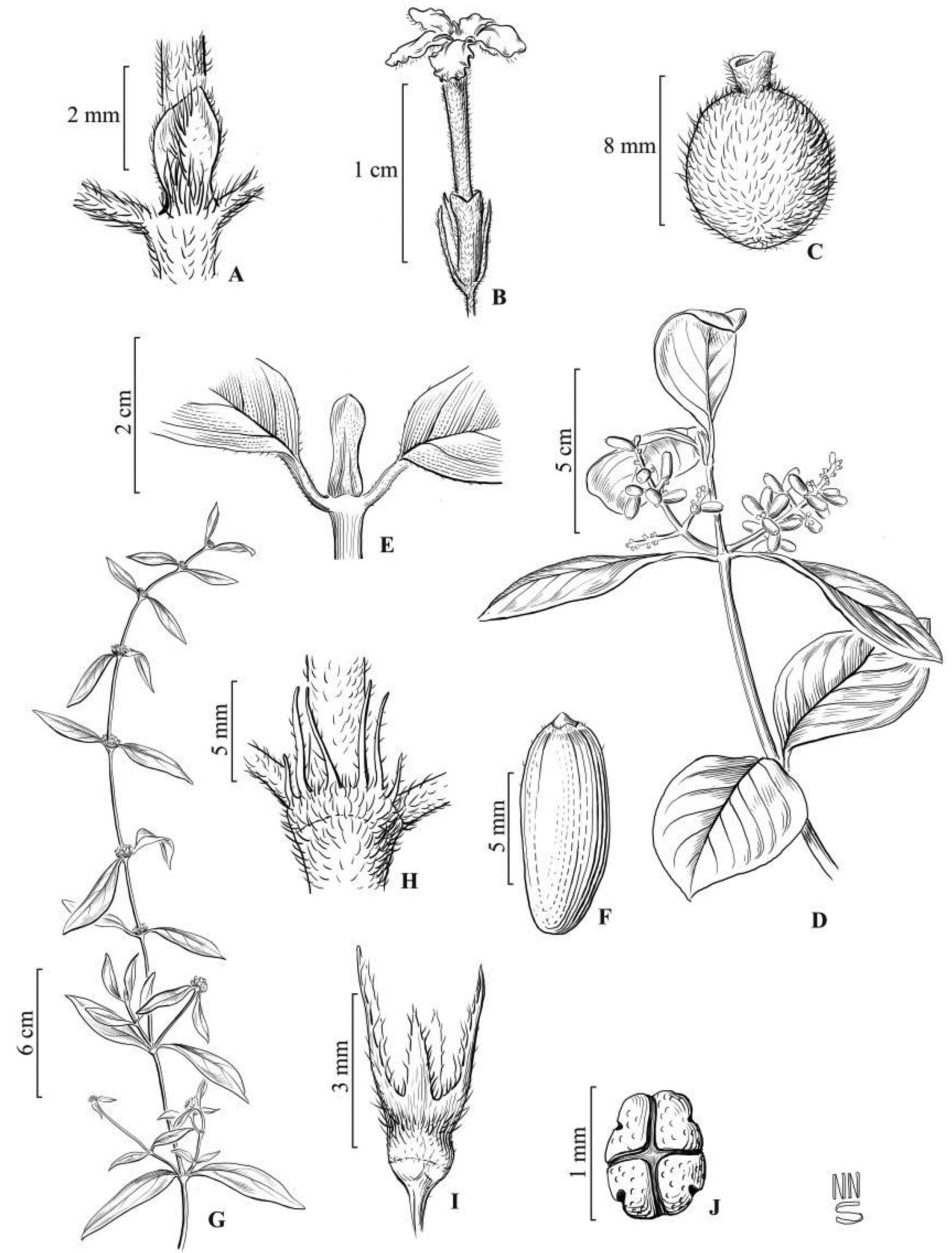

Figura 5. A-C. Guettarda sericea - A. estípula; B. flor, hipanto e bractéolas; C. fruto. D-F. Malanea macrophylla - D. ramo frutífero; E. estípula do ápice; F. fruto. G-J. Mitracarpus frigidus - G. ramo florífero; H. estípula; I. fruto; J. semente, face dorsal. (A-C. L.A. Sousa 549; D-F. L.A. Sousa 450; G-J. L.A. Sousa 373).

Figure 5. A-C. Guettarda sericea - A. stipule; B. flower hypanthium and bracteoles; C. fruit. D-F. Malanea macrophylla - D. fruitful branch; E. stipule apex; F. fruit. G-J. Mitracarpus frigidus - G. flowering branch; H. stipule; I. fruit; J. dorsal surface of seed. (A-C. L.A. Sousa 549; D-F. L.A. Sousa 450; G-J. L.A. Sousa 373). 
margem plana; ambas as faces glabras; venação broquidódroma, nervuras secundárias visíveis na face adaxial, plicado nervosa, proeminentes na face abaxial, 10-15 pares. Inflorescências panículas, terminais, multifloras, pedúnculo $40-90 \mathrm{~mm}$ compr. pedúnculo 30-60 mm compr. delgado, amarelo 1 bráctea, linear, bractéolas inconspícuas. Flores monoclinas, heterostílicas, pedicelo 2-5 mm compr., glabro ou pubérulo; cálice truncado, 5 lobos iguais, 0,1-0,4 mm compr., ovados a triangulares, glabros; corola amarela, tubular, base gibosa, tubo 8-12 mm compr., externamente glabro, internamente pubescente, anel de tricomas na porção inferior, 5-6-mera, lobos 2-3,5 mm compr., triangulares ou ovado-oblongos., pubérulos; anteras 3-4 mm compr., oblongas; estigma bífido; flores brevistilas, estames inseridos na porção mediana do tubo, porção livre dos filetes 3,5-4 mm compr.; estiletes 10-12 mm compr., flores longistilas, estames inseridos na fauce da corola, porção livre dos filetes 3-3,5 mm compr.; estiletes 14-16 mm compr. Fruto drupa 4-5,5 × 3-4, ovoide, azul-escuro a atropurpúreo na maturação, glabro, 3-5 costadas; sementes não observadas.

Distribuição: Ocorre no México, Caribe, Brasil e Bolívia (Taylor et al. 2007). No Brasil, não há registros apenas nas regiões Sudeste e Sul (Zappi \& Taylor 2012).

Palicourea guianensis pode ser facilmente reconhecida na área pelo porte robusto com folhas amplas [(65-)120-180], e através da inflorescência laxa, paniculada com flores amarelas, vistosas. Foi encontrada em floresta estacional com vegetação úmida e sombreada, sobre solo argiloso, entre 780-890 m de altitude. Floresce na área em setembro, outubro, novembro, dezembro e frutifica em março.

Material examinado: BRASIL. BAHIA: Pindobaçu, Serra da Fumaça. $10^{\circ} 40$ ' 02" S e 40²1' 43" W, 18/XI/2011, fl., L.A. Sousa 458 (HUNEB); 29/IX/2011, fl., L.A. Sousa 425 (HUNEB); 20/I/2012, fr., L.A. Sousa 522 (HUNEB); $10^{\circ} 39^{\prime} 49^{\prime \prime} \mathrm{S}$ e $40^{\circ} 22^{\prime} 21^{\prime \prime} \mathrm{W}, 18 /$ XI/2009, fl., L.A. Sousa 175 (HUNEB); 29/VI/2011, fl., fr. L.A. Sousa 325 (HUNEB); 18/XI/2011, fl., L.A. Sousa 459 (HUNEB); 18/XI/2011 fl., L.A. Sousa 470 (HUNEB).

24. Palicourea marcgravii A.St.-Hil., Pl. Rem. Bres. 22: 231. 1824.

Arbusto ereto, 0,8-2 m alt., monoico; caule cilíndrico, sem lenticelas, pubescente na base, pubérulo a híspido no ápice, entrenós 50-150 mm compr. Estípulas persistentes, 2,5-4 × 3-4 mm compr., bífidas, concrescidas na base, lanceoladas, pubérulas. Folhas opostas, pecíolo de 3-5 mm compr., glabro a hirsuto; lâmina 60-130 × 25-55 mm, ovada, oblongo-ovada a elíptica, base aguda a decurrente, ápice agudo a longo-acuminado, margem plana; ambas as faces pubescentes a hirsutas, levemente estrigosa nas nervuras; venação broquidódroma, nervuras proeminentes em ambas as faces, 9-12 pares. Inflorescências panículas, terminais, multifloros, pedúnculo 25-70 $\mathrm{mm}$ compr., delgado, vermelho, glabro a hispido; 2 brácteas foliáceas, linear-lanceoladas, bractéolas inconspícuas. Flores monoclinas, heterostílicas, pedicelo $5 \mathrm{~mm}$ compr.; cálice 5 lobos iguais, 1-2 mm compr., estreito-triangulares, tomentoso; corola laranja a rósea, tubular, base gibosa; tubo 12-20 mm compr., externamente pubescente, anel de tricomas próximo da base, 5-mera, lobos 1,8-2,5 mm compr., estreito-triangulares, externamente pubescentes; anteras 1-1,2 mm compr., lanceoladas; estigma bífido; flores brevistilas, estames inseridos na porção mediana do tubo, porção livre dos filetes, 3,8-4,5 mm compr.; estiletes 10-12 mm compr., flores longistilas, estames inseridos na fauce, porção livre dos filetes 2-2,8 mm compr.; estiletes 16-20 mm compr. Fruto drupa 3,5-55 × 3,5-6 mm, ovoide, vináceo na maturação, glabra a levemente pilosa, 3 costadas; semente $2,5-3 \times 1,8 \mathrm{~mm}$, planoconvexas, castanhas, superfície ventral sulcada longitudinalmente, superfície dorsal lisa.
Distribuição: É amplamente distribuída no Brasil, ocorrendo na bacia Amazônica, no Nordeste, Centro-Oeste até o Sul tendo como limite o estado de São Paulo (Delprete 2010b).

Caracteriza-se por apresentar inflorescências com raque vermelho e corola laranja ou lilás, com lobos róseos. Foi encontrada apenas na base da serra, associada à floresta de galeria e floresta de encosta, entre 400-700 m altitude, sempre em locais sombreados. Floresce e frutifica na área em quase todos os meses do ano.

Material examinado: BRASIL. BAHIA: Pindobaçu, trilha para Serra. $10^{\circ} 40^{\prime} 03$ " S e $40^{\circ} 21^{\prime} 30$ " W, 18/V/2008, fl., L.A. Sousa 90 (HUNEB); 26/VI/2011, fl., L.A. Sousa 322 (HUNEB); 23/VI/2011, fr., L.A. Sousa 361 (HUNEB); 26/VIII/2011, fl., L.A. Sousa 388 (HUNEB); 15/XI/2011, fl., L.A. Sousa 459 (HUNEB); 20/II/2011, fl., L.A. Sousa 535 (HUNEB); 20/I/2012, fl., L.A. Sousa 548 (HUNEB); 18/II/2012, fl., L.A. Sousa 551 (HUNEB); 18/IV/2012, fl., fr., L.A. Sousa 585 (HUNEB); 18/V/2012, fl., L.A. Sousa 588 (HUNEB); $10^{\circ}$ 39' 59" S e 40²1' 59" W, 18/VI/2011, fl., L.A. Sousa 591 (HUNEB).

25. Perama harleyi J.H.Kirkbr. \& Steyerm., Brittonia 29: 194 (-195). 1977.

Figura 6E-G

Erva ereta, 16-30 cm alt., monoica, caule cilíndrico, sem lenticelas, glabro ou com tricomas adpressos no ápice, entrenós 20-45 mm compr. Estípulas reduzidas a uma linha ou uma bainha inconspícua, pilosa. Folhas opostas, cartáceas, sésseis; lâmina 1,5-4 × 0,1-1 mm, lanceolada a linear lanceolada, base cuneada, ápice agudo, margem plana; face adaxial glabra, abaxial hirsuta; nervuras secundárias inconspícuas. Inflorescências em dicásios laxos, axilares e terminais, 2-4-flores, pedúnculo 4-12 mm compr., piloso; 2-4 brácteas, foliáceas, lanceolado-ovadas, bractéolas inconspícuas. Flores monoclinas, homostílicas, sésseis, cálice 2-lobado, lobos iguais, 1-5 1,8 mm compr., lanceolados, hirsuto; corola branca a rósea, infundibuliforme, tubo 3-4 mm compr., externamente hirsuta, anel de tricomas na inserção dos filetes, 4-mera, lobos 0,8-1 mm compr., ovados, pubérulos internamente; estames exsertos, inseridos na fauce da corola, porção livre dos filetes $0,1 \mathrm{~mm}$ compr., anteras $0,5 \mathrm{~mm}$ compr., estreito-elípticas; estigma bífido, estilete $4-5 \mathrm{~mm}$ compr. Fruto cápsula, $1,1 \times 1 \mathrm{~mm}$, deiscência longitudinal, marrom-escuro na maturação, hirsuta; sementes $0,7 \times 0,8 \mathrm{~mm}$, hemisférica.

Distribuição: Espécie endêmica da Bahia, encontrada em fitofisionomias de Caatinga e Cerrado (Zappi 2012b).

Caracteriza-se por apresentar caule ereto, delicado, geralmente ramificado com até $30 \mathrm{~cm}$ alt., inflorescências em dicásios laxos e flores róseas. Foi encontrada em vegetação de transição entre floresta e campo rupestre, sobre solos arenosos e rupestres, entre 890-900 m altitude. Floresce e frutifica na área nos meses junho, agosto, setembro e novembro.

Material examinado: BRASIL. BAHIA: Pindobaçu, Serra da Fumaça. $10^{\circ} 39^{\prime} 54,6$ " S e $40^{\circ} 22$ ' 22" W, 27/VIII/2011, fl., fr., L.A. Sousa 410 (HUNEB); 29/IX/2009, fl., fr., L.A. Sousa 280 (HUNEB); $10^{\circ} 39^{\prime} 26^{\prime}$ ' S e $40^{\circ} 22^{\prime} 18^{\prime}$ " W, 27/VIII/2011, fl., fr., L.A. Sousa 450 (HUNEB); $10^{\circ} 38^{\prime} 57^{\prime}$ ' S e $40^{\circ} 22^{\prime} 31$ ' W, 18/XI/2011, fl., fr., L.A. Sousa 465 (HUNEB).

\section{Perama hirsuta Aubl., Hist. Pl. Gui. Franç. 1: 54.1775.}

Figura $6 \mathrm{H}-\mathrm{K}$

Erva ereta, 12-20 cm alt., monoica; caule cilíndrico, sem lenticelas, hirsuto, entrenós 2-12 mm compr. Estípulas reduzidas a uma linha. Folhas opostas, membranáceas, sésseis; lâmina 3-7 $\times$ 4-8 mm, ovada a lanceolado-ovada, base arredondada, ápice agudo, margem plana; ambas as faces hirsutas, venação paralelódroma, nervuras secundárias proeminentes na face abaxial, 3-4 pares. Inflorescências em glomérulos, axilares e terminais, 1-4 por ramo florífero, multifloros, pedúnculo 5-10 mm compr., hirsuto; 2-4 brácteas, foliáceas, lanceolado-ovadas, bractéolas inconspícuas. 


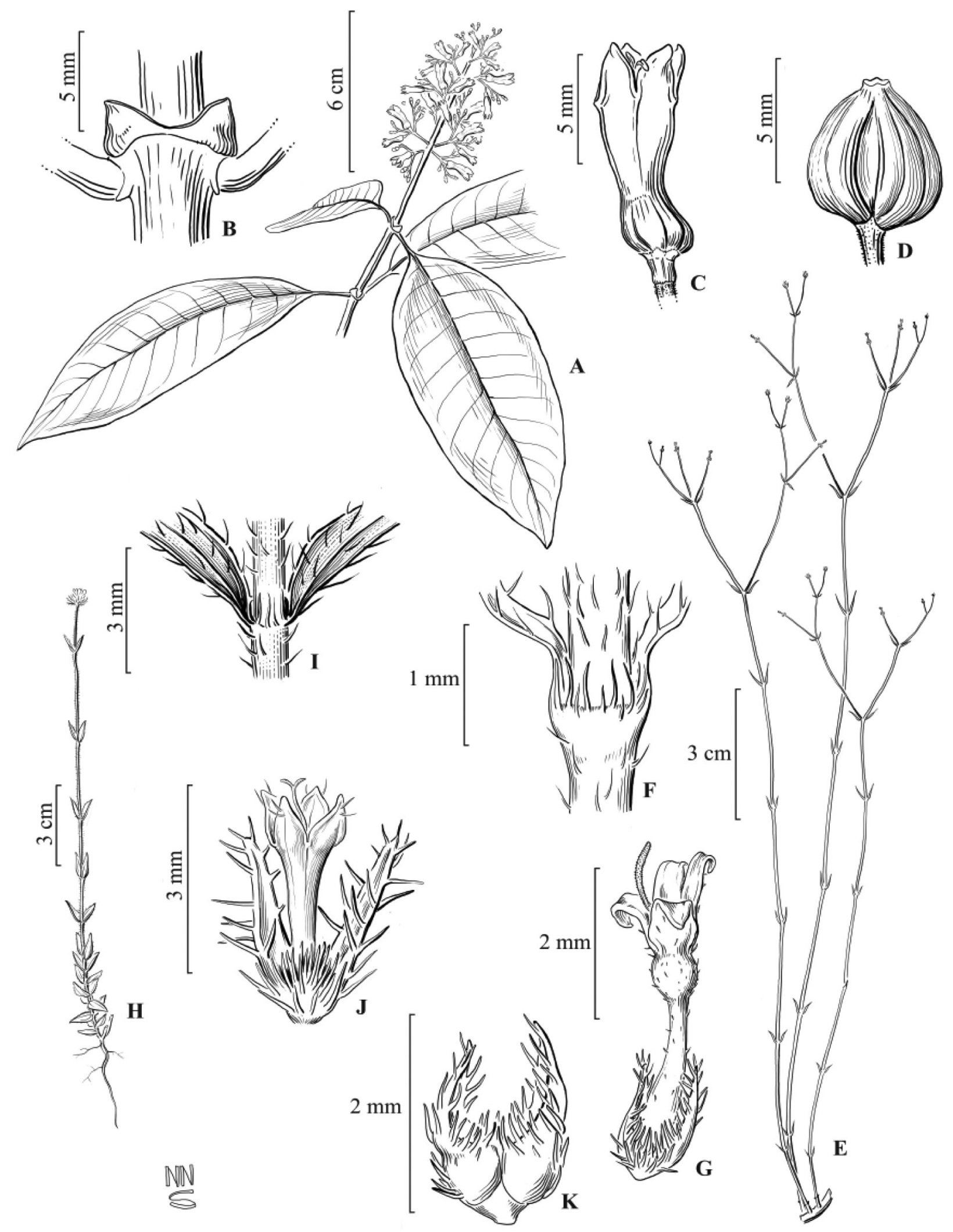

Figura 6. A-D. Palicourea guianensis - A. ramo florífero; B. estípula; C. flor; D. fruto. E-G. Perama harleyi- E. ramo florífero; F. detalhe do nó e linha estípular; G. flor. H-K. Perama hirsuta - H. ramo florífero; I. detalhe do nó e linha estípular; J. flor; K. fruto. (A-D. L.A. Sousa 458; E-G. L.A. Sousa 410; H-K. L.A. Sousa 408).

Figure 6. A-D. Palicourea guianensis - A. flowering branch; B. stipule; C. flower; D. fruit. E-G. Perama harleyi - E., flowering branch, F. node detail and stipule line, G. Flower. H-K. Perama hirsuta - H. flowering branch, I. node detail and stipule line, J. Flower; K. fruit. (A-D. L.A. Sousa 458; E-G. L.A. Sousa 410; H-K. L.A. Sousa 408). 
Flores monoclinas homostílicas, sésseis; cálice 2 lobos iguais, 0,5-0,8 mm compr., estreito triangulares, hirsutos; corola amarela, infundibuliforme; tubo 2,5-3 mm compr., externamente glabro, anel de tricomas na inserção dos filetes, 5-mera, lobos 0,5-1 mm compr., triangulares, pilosos no ápice; estames inclusos a parcialmente exsertos, presos na fauce da corola; porção livre dos filetes $0,1-0,2 \mathrm{~mm}$ compr.; anteras 0,7-0,8 mm compr., oblongo-lineares; estigma bífido, filete 3-3,4 mm compr. Fruto cápsula 2-3 × 1-2 mm, subgloboso, deiscência transversal circuncisa, amarelo-esverdeado, hirsuto; sementes com 0,3-0,7 $\times 0,2-0,5 \mathrm{~mm}$, com estrias transversais.

Distribuição: Ocorre no México, América Central, Antilhas, nordeste e sudeste da América do Sul (Taylor et al. 2004). No Brasil, ocorre em quase todas as regiões, exceto na Sul (Zappi 2012b).

Caracteriza-se por apresentar caule delicado com até $20 \mathrm{~cm}$ alt., hirsutos e corola amarela. Na Serra da Fumaça, foi encontrada associada ao campo rupestre, sobre solos arenosos, em locais abertos a $840 \mathrm{~m}$ de altitude. Floresce e frutifica na área no mês de agosto.

Material examinado: BRASIL. BAHIA: Pindobaçu, Serra da Fumaça. $10^{\circ} 39 ' 54,6$ " S e $40^{\circ} 22^{\prime} 20^{\prime \prime} \mathrm{W}, 27 / \mathrm{VIII} / 2011$, fl., fr., L.A. Sousa 408 (HUNEB); 29/VIII/2009, fl., fr., L.A. Sousa 280 (HUNEB).

Material adicional examinado: BRASIL. BAHIA: Morro do Chapéu, Rio do Ferro Doido, 17/VII/1979, fl., G. Hatschbach 42432 (CEPEC); 31/V/1980, fl., fr., R. Harley 22480 (CEPEC); Mucugê, Gobira, 30/X/2009, fl., fr., A.A. Conceição 3163 (HUEFS); Lençóis, Serra da Chapadinha, 31/IV/2000, fl., T.S. Nunes 182 (HUEFS); Rio de Contas, 25/VII/1983, fl., fr., G. Hatschbach 46948 (HUEFS).

27. Posoqueria latifolia (Rudge) Roem. \& Schult., Syst. Veg. 5: 227.1819.

Figura 7A-C

Árvore, 5-7 m de alt., monoica, caule cilíndrico, sem lenticelas, glabro, entrenós 25-35 mm compr. Estípulas persistentes, geralmente escariosas, 6-12 × 8-10 mm, inteira, triangulares, ápice agudo, glabras. Folhas opostas, cartáceas, pecíolos $5-15 \mathrm{~mm}$ compr., glabros; lâmina (55) $80-130 \times(25)$ 35-50 mm, oblonga a elíptica, base arredondada a truncada, ápice obtuso-acuminado, agudo, margem plana, glabras; venação broquidódroma, nervuras proeminentes em ambas as faces, 5-7 pares. Inflorescências em corimbos, terminais, 5-10-flores, pedúnculo 20-30 $\mathrm{mm}$ compr., glabro; brácteas e bractéolas inconspícuas. Flores monoclinas, homostílicas, pedicelos 0,8-1,6 mm compr., glabro; cálice 5-lobado, lobos iguais, 0,5-1,8 mm compr., triangulares, externamente ciliados; corola branca, hipocrateriforme, tubo 85-140 mm compr., externamente glabro, internamente papilosos, 5-mera, lobos 10-18 mm compr., oblongo-lanceolados, papilosos; estames exsertos, inseridos na fauce, porção livre dos filetes 6-13 cm compr., anteras 5-6 mm, lineares; estigma bífido, estilete 60-100 mm compr. Frutos bacáceos, 45-60 × 25-40 mm, globosos, lenhosas, alaranjados na maturação, glabros; sementes, 8-10 x 6-5 mm compr., subglobosas, lisas.

Distribuição: Está distribuída no México, América Central, Antilhas, Guianas, e da Colômbia até o Brasil (Taylor et al. 2004). No Brasil é amplamente distribuída, ocorrendo em todas as regiões e em quase todos os estados (Barbosa 2012c).

Caracteriza-se por apresentar hábito arbóreo, e através das flores brancas com tubo longo (85-140 mm compr.). Foi encontrada associada à Floresta Estacional, sobre solo argiloso, entre 890-900 m altitude. Floresce na área apenas no mês de novembro.

Material examinado: BRASIL. BAHIA: Pindobaçu, Serra da Fumaça. $10^{\circ} 39^{\prime} 13,6$ " S e $40^{\circ} 22$ ' 22,5" W, 18/XI/2011, fl., L.A. Sousa 467 (HUNEB); 18/XI/2011, fl., L.A. Sousa 469 (HUNEB).

Material adicional examinado: BRASIL. BAHIA: Lençóis, Rio Mandassaia, 03/V/2007, fr., A.A. Conceição 2524 (ALCB, HUEFS,); Rio de Contas, Itoboira, 18/XI/1998, fl., F.H.F. Nascimento
86 (HUEFS); Serra das Almas, 07/VII/2006, fr., F.H.F. Nascimento 526 (HUEFS); 28/XI/1988, fr., R.M. Harley 26654 (ALCB, CEPEC).

28. Psychotria hoffmannseggiana (Willd. ex Schult.) Müll.Arg., Fl. Bras. 6(5): 336. 1881.

Figura $7 \mathrm{H}-\mathrm{I}$

Erva a subarbusto, $40-80 \mathrm{~cm}$ alt., monoica; caule cilíndrico ou geniculado em alguns pontos, sem lenticelas, glabro, entrenós 25-70 mm compr. Estípulas persistentes, 2-3 × 3-5 mm, bífidas, lanceoladas a oblanceoladas, ápice agudo, glabra a pilosa. Folhas opostas, cartáceas, pecíolos 2-6 mm compr., glabros; lâmina 35-95 $\times$ 20-45 mm, ovada, elíptica, oblongo-elíptica, base obtusa a aguda, ápice agudo a atenuado, margem plana; face adaxial glabra, abaxial esparso pubérula nas nervuras; venação broquidódroma, nervuras secundárias proeminentes na face abaxial, 6-8 pares. Inflorescências subcapitadas, terminais ou axilares, pêndulas, multifloras, pedúnculo 5-10 mm compr., glabro; 4 brácteas, lanceoladas, bractéolas oblonga a lanceoladas. Flores monoclinas, heterostílicas, sésseis; cálice cupular, denteado, 5 lobos iguais, 0,2-0,4 mm compr., triangulares, pilosos; corola rósea, infundibuliforme, tubo 5-6 $\mathrm{mm}$ compr., externamente glabro, densamente pubescente internamente, 5-mera, lobos 1,8-2,1 mm compr., ovado-triangulares, pubérulos; estames inseridos na porção mediana do tubo; anteras $8-2 \mathrm{~mm}$ compr., oblongas; estigma bífido; flores longistilas, porção livre dos filetes $0,6-0,8 \mathrm{~mm}$ compr.; estiletes $6,5-7,5 \mathrm{~mm}$ compr.; flores brevistilas, porção livre dos filetes 1,3-2,8 mm compr., estiletes 3,5-4 mm compr. Frutos drupoides, 3-4 × 3-3,5 mm, globosos a subglobosos, azul-escuro a atropurpúreos na maturação, glabro a pubérulo; pirenos 2, com 4-5 costas longitudinais; sementes não observadas.

Distribuição: Distribui-se na Colômbia, Equador, Peru, Guianas, Venezuela e Brasil (Steyermark 1972). No Brasil, ocorre em todas as regiões e em quase todos os estados desde a bacia Amazônica até o Centro-Oeste e Centro-Sul (Delprete 2010b).

Caracteriza-se por apresentar caule geralmente geniculado, através das folhas avermelhadas após a secagem e pelas inflorescências pêndulas, subcapitadas e circundadas por brácteas lanceoladas. Encontra-se bem distribuída na área, associada a quase todas as áreas florestadas, sobre solo argiloso, entre 452-898 m altitude. Floresce e frutifica na área em quase todos os meses do ano.

Material examinado: BRASIL. BAHIA: Pindobaçu, Serra da Fumaça. $10^{\circ} 39^{\prime} 46^{\prime}$ 'S e $40^{\circ} 20^{\prime} 48^{\prime \prime} \mathrm{W}$; 26/VIII/2011, fr., L.A. Sousa, 401 (HUNEB); $10^{\circ} 39^{\prime} 55^{\prime}$ ' S e 40 20' 51' W, 21/I/2012, fl., L.A. Sousa 519 (HUNEB); 28/VI/2011, fl., L.A. Sousa 321 (HUNEB); $10^{\circ}$ 39' 47' S e 40²2' 25' W, 29/VI/2011, fl., L.A. Sousa 329 (HUNEB); 29/VI/2011, fr., L.A. Sousa 336 (HUNEB); 26/VII/2011, fl., L.A. Sousa 374 (HUNEB); 20/I/2012, fl., L.A. Sousa 527 (HUNEB).

29. Psychotria jambosioides Schltdl., Linnaea 28: 518. 1857.

Figura 8A-D

Arbusto, 2,5-3 m de alt., monoico; caule cilíndrico, sem lenticelas, glabro, entrenós 5-70 mm compr. Estípulas persistentes, 5-10 × 3-3 mm, bipartidas ao menos no ápice, triangulares, ápice agudo, glabra. Folhas opostas, cartáceas, pecíolo 8-12 mm compr.; lâmina 35-150 × 23,50 mm, oblonga, oblanceolada a linear-lanceolada, base atenuada, ápice agudo a acuminado, raro cuspidado, margem plana; face adaxial glabra, a abaxial glabra a levemente pilosa; venação broquidódroma, nervuras secundárias inconspícuas em ambas as faces, 11-15 pares. Inflorescências paniculadas, subterminais, multifloras, pedúnculo 30-60 mm compr., espesso, branco ou lilás, glabro; 2 brácteas foliáceas, oblanceoladas, bractéolas lanceoladas. Flores monoclinas, heterostílicas, sésseis; cálice denteado, lobos 0,8-1 mm compr., agudos, pubescentes; corola lilás, tubular, base gibosa, tubo 8-20 mm compr., externamente glabro, internamente anel de tricomas próximo da inserção dos filetes, 5-mera, lobos 1,5-2 mm compr., largo-elíptico, pubescentes; 


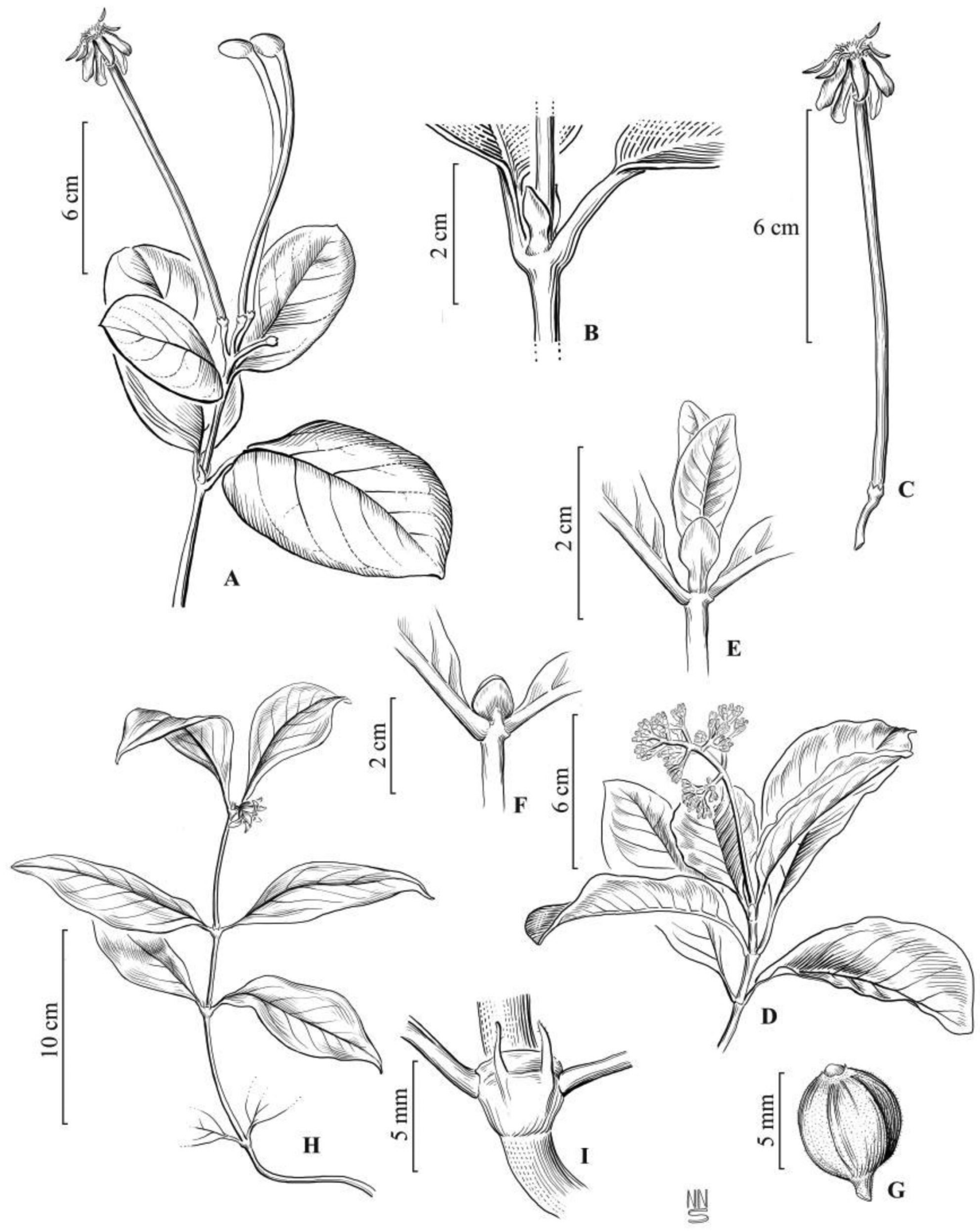

Figura 7. A-C. Posoqueria latifolia - A. ramo florífero; B. estípula; C. flor. D-G. Psychotria mapourioides - D. ramo florífero; E. estípula em botão; F. estípula e folhas jovens; G. fruto. H-I. Psychotria hoffmannseggiana - H. ramo florífero; I. estípula. (A-C. L.A. Sousa 458; D-F. L.A. Sousa 410; H-I. L.A. Sousa 408). Figure 7. A-C. Posoqueria latifolia - A. flowering branch; B. stipule; C. flower. D-G. Psychotria mapourioides - D. flowering branch; E. stipule bud; F. stipule and young leaves; G. fruit. H-I. Psychotria hoffmannseggiana - H. flowering branch; I. stipule. (A-C. L.A. Sousa 458; D-F. L.A. Sousa 410; H-I. L.A. Sousa 408). 
estames inseridos na porção mediana do tubo; estigma bífido; flores longistilas, estames inclusos, sésseis, anteras estreito-elípticas, 2-2,5 mm compr., estiletes 4-4,5 mm compr.; flores brevistilas, porção livre dos filetes $0,2-0,6 \mathrm{~mm}$ compr.; anteras 1,5-2 $\mathrm{mm}$ compr., elipsoides; estiletes 2-2,5 mm compr. Fruto drupáceo, 5-6 $\times 4-4,5 \mathrm{~mm}$, elipsoide, subglobosa, roxa a verde, quando imatura, glabra; pirenos 2, hemisféricos, com 5 costas, longitudinais arredondadas.

Distribuição: Espécie endêmica do Brasil, ocorrendo nos estados da Bahia e Espírito Santo, no domínio Mata Atlântica (Taylor 2012).

Diferencia-se das demais através das folhas com nervuras secundárias inconspícuas em ambas as faces, da inflorescência com raque e pedúnculos espessos e corola roxa. Foi encontrada associada ao subosque da Floresta Estacional, sobre solos argilosos, a 800-900 m altitude. Floresce na área em abril, setembro, novembro, dezembro, janeiro e frutifica em junho, setembro, dezembro, março e maio.

Material examinado: BRASIL. BAHIA: Pindobaçu, Serra da Fumaça. $10^{\circ} 39 ' 54$ " S e $40^{\circ} 22$ ' 22" W, 22/V/2008, fl., L.A. Sousa 37 (HUNEB); 29/XI/2009, fl., L.A. Sousa 261 (HUNEB); 26/X/2008, fl., L.A. Sousa 174 (HUNEB)26/VII/2011, fr., L.A. Sousa 334 (HUNEB); 26/XII/2011, fr., L.A. Sousa 503 (HUNEB); 10 39' 54"' S e $40^{\circ} 22$ ' 22" W, 26/VIII/2011, fl., fr. L.A. Sousa 406 (HUNEB); 18/XI/2011, fl., L.A. Sousa 464 (HUNEB); 20/I/2012, fr., L.A. Sousa 524, (HUNEB); $10^{\circ} 39^{\prime} 29^{\prime \prime} \mathrm{S}$ e $40^{\circ} 22^{\prime} 21^{\prime \prime} \mathrm{W}, 17 / \mathrm{V} / 2012$, fr., L.A. Sousa 576 (HUNEB).

\section{Psychotria mapourioides DC., Prodr. 4: 509 (1830).}

\section{Figura 7D-G}

Arbusto ou arvoreta, 3-6 m alt., monoica; caule cilíndrico, lenticelado, glabro ou levemente pubérulo no ápice, entrenós 10-70 mm compr. Estipulas decíduas, 5-9 × 4-8, inteiras, espatuladas a ovadas, ápice arredondo a obtuso, glabra. Folhas opostas, cartáceas, pecíolos 1-1,8 cm compr., glabros; lâmina 110-200 × 40-80 mm, elíptica a oblanceolada, base cuneada, ápice acuminado a cuspidado, margem plana, face adaxial glabra, a abaxial esparso pubérula na nervura principal; venação broquidódroma, proeminentes na face abaxial, 8-12 pares. Inflorescências paniculadas, terminais, 3-7-flores, pedúnculo 30-85 mm compr., pubescente; 2 brácteas foliáceas, triangulares, bractéolas inconspícuas. Flores monoclinas, heterostílicas, sésseis, cálice truncado, lobos inconspícuos, ápice pubérulos; corola alva, infundibuliforme; tubo 2-3 $\mathrm{mm}$ compr., densamente piloso próximo da fouce, 5-mera, lobos 3-4 mm compr., oblongo-lanceolados, glabro a pubérulo na base; estames, inseridos próximo da base do tubo; anteras 2-2,1 compr., estreito-elíptica; estigmas bífidos; flore longistilas, porção livre dos filetes $0,5-0,8 \mathrm{~mm}$ compr.; estilete 3,5-4 mm compr.; flores brevistilas, porção livre dos filetes 2-2,8 mm compr.; estilete 1,8-2,1 mm compr. Fruto drupoide, 5-6 × 6-7 mm compr., elipsoide a subgloboso, vermelha na maturação, glabras; pirenos 2, com 3-5 costas longitudinais; sementes não observadas.

Distribuição: Ocorre desde a Venezuela até o Sul do Brasil (Taylor 2007). No Brasil, a espécie foi citada para a região Norte (AC, AM, PA e RO) e para o Sudeste, apenas em São Paulo (Taylor 2012).

Caracteriza-se por apresentar estípulas espatuladas a ovadas, decíduas e através dos frutos laranja à vermelhos na maturidade. Em herbários pode ser confundida com Psychotria carthagenensis Jacq. devido às folhas com tamanho e formato semelhantes e pela inflorescência paniculada, com flores brancas. Difere-se desta através do porte mais robusto e principalmente através das estípulas com ápice patente $v s$ reflexo. Foi encontrada associada à Floresta Estacional, sobre solo argiloso, entre 880-890 m de altitude. Floresce na área em dezembro e janeiro e frutifica em maio e julho.

Material examinado: BRASIL. BAHIA: Pindobaçu, Serra da Fumaça. $10^{\circ} 39^{\prime} 25^{\prime}$ ' S e $40^{\circ} 22^{\prime} 25^{\prime}$ 'W, 26/XII/2011, fl., L.A. Sousa
502 (HUNEB); 20/I/2012, fl., fr., L.A. Sousa 529 (HUNEB); 18/ XI/2011, fl., L.A. Sousa 568 (HUNEB); 20/IV/2012, fl., L.A. Sousa 589 (HUNEB); 18/V/2012, fr., L.A. Sousa 598 (HUNEB).

31. Richardia brasiliensis Gomes, Mem. sobre Ipecac. 31. 1801.

Erva prostrada, ca. $10 \mathrm{~cm}$ alt., monoica; caule tetrágono, sem lenticelas, base vilosa, ápice setosos, entrenós 30-55 mm compr. Estípulas fimbriadas, persistentes, bainha 2-2,5 $\times 2-3 \mathrm{~mm}$ compr., pubescente, 3-4 setas desiguais, 2-4 mm compr., pilosas. Folhas opostas, cartáceas, pecíolo 1-3 mm compr., hirsuto; lâmina 8-28 $\times$ 3-10 mm, obovada, elíptica, oblanceolada a oblonga, base atenuada, ápice agudo-mucronado, margem plana; face adaxial híspida, abaxial escabrosa; venação eucamptódroma, nervuras secundárias proeminentes na face abaxial, 2-4 pares. Inflorescências em glomérulos, axilares e terminais, 1-3 por ramo florífero, multifloras; 4-6 brácteas, foliáceas, ovadas a obovadas, bractéolas lanceoladas. Flores monoclinas, homostílicas, sésseis; cálice 6 lobos iguais, 1,5-2 mm compr., linear-lanceolados, híspido a escabro; corola rósea a branca, infundibuliforme; tubo 2-3 $\mathrm{mm}$ compr., externamente glabro, anel de tricomas próximo da base; 6-mera, lobos 3-3,2 mm compr., triangular a elíptico, pilosos; estames exsertos, presos na fauce, porção livre dos filetes 1-2 mm compr., anteras 1,5-2 mm compr. elipsoides; estigma trífido, estiletes 3,8-4 mm, excertos. Fruto esquizocarpo, 5-6,2 × 3-4,2 $\mathrm{mm}$, oblongo-ovado, pardo a castanho na maturação, deiscência lateral, três mericarpos comprimidos dorsiventralmente, amplamente sulcado, dorso pubérulo com papilas lanceoladas; sementes não foram observadas.

Distribuição: Distribui-se por toda a América, Argentina, Bolívia, Paraguai, Uruguai (Schumann 1888, Lewis \& Oliver 1974). No Brasil é amplamente distribuída, ocorrendo em todas as regiões.

Richardia brasiliensis diferencia-se de $R$. grandiflora através das estípulas com setas pubescentes ( $v s$ hirsutas), qanto comprimento do tubo da corola (2-3 vs 3-5,5 mm), através dos frutos com mericarpos apresentando papilas lanceoladas e longas no dorso vs curtas e arredondadas. Foi encontrada apenas associada à margem da trilha, em áreas abertas, sobre solo argiloso, a 460-480 m altitude. Floresce e frutifica na área no mês de junho, período chuvoso.

Material examinado: BRASIL. BAHIA: Pindobaçu, Serra da Fumaça, $10^{\circ} 39^{\prime} 54,6^{\prime}$ ' S e $40^{\circ} 22^{\prime}$ '22' W, 19/XI/2011, fl., fr., L.A. Sousa 476 (HUNEB); 29/VI/2012, fl., fr., L.A. Sousa 601 (HUNEB).

Material adicional examinado: BRASIL. BAHIA: Senhor do Bonfim, 25/II/1974, fl., R.M. Harley 16341 (CEPEC); Sítio Cristiana, 19/IV/2011, fl., J.O. Santos et al. 1 (HUEFS).

32. Richardia grandiflora (Cham. \& Schltdl.) Steud., Nomencl. Bot. 2: 459. 1841.

Erva prostrada, ca. $10 \mathrm{~cm}$ alt., monoica; caule tetrágono, sem lenticelas, base vilosa, ápice setoso, entrenós 30-65 mm compr. Estípulas fimbriadas, persistentes, bainha 2-3 × 3-5 mm compr., pubérula a hirsuta, 3-5 setas desiguais, 0,3-5 mm compr., pilosas. Folhas opostas, cartáceas, sésseis; lâmina 10-40 × 5-20 mm, obovada, elíptica, oblanceolada a oblonga, base atenuada, ápice agudomucronado, margem plana; face adaxial híspida, abaxial escabrosa; venação eucamptódroma, nervuras secundárias proeminentes na face abaxial, 2-3 pares. Inflorescências em glomérulos, axilares e terminais, 1-3 por ramo florífero, multifloras; 4-6 brácteas, foliáceas, ovadas a obovadas, bractéolas lanceoladas. Flores monoclinas, homostílicas, sésseis; cálice 6 lobos iguais, 1,8-2,8 mm compr., linearlanceolados, híspido a escabro, hirsuto nas margens; corola rósea ou alva, infundibuliforme; tubo 3-5,5 mm compr., externamente glabro, internamente com anel de tricomas próximo da base; 6-mera, lobos 1,5-2 mm compr., triangular a elíptico, pilosos; estames exsertos, presos na fauce, porção livre dos filetes 1-2 mm compr., anteras 1,5-2 mm compr., elipsoides; estigma trífido, estiletes 3,8-4 mm compr., exserto. Fruto esquizocarpo, 5-5,5 × 2-3,5 mm, oblongo- 
ovado, pardo a castanho na maturação, deiscência longitudinal, três mericarpos comprimidos dorsiventralmente, sulco estreito, dorso pubérulo, com papilas curtas e arredondadas; sementes 1-0,2 $\times 0,05-0,1 \mathrm{~mm}$, ovaladas, marrons, muricadas.

Distribuição: Distribui-se por toda a América e como planta introduzida na Flórida, Estados Unidos. No Brasil, ocorre em todas as regiões, nos domínios de Caatinga, Cerrado e Mata Atlântica (Delprete 2010b, Cabral \& Salas 2012d).

Caracteriza-se por apresentar tubo da corola longo (3-5,5 mm compr.) e através dos frutos com mericarpos amplamente sulcados, com papilas lanceoladas. Foi encontrada em áreas abertas, associada à margem da trilha, sobre solo argiloso a 400-480m altitude. Floresce e frutifica na área apenas no mês de junho, período chuvoso.

Material examinado: BRASIL. BAHIA: Pindobaçu, Serra da Fumaça. $10^{\circ} 39^{\prime} 54,6$ " S e $40^{\circ} 22$ ' 22 ' 'W, 29/VI/2012, fl., fr., L.A. Sousa 605 (HUNEB).

33. Sabicea grisea Cham. \& Schltdl., Linnaea 4: 192. 1829.

Figura 8E-H

Liana, monoica; caule lenhoso, cilíndrico, sem lenticelas, pubérulo, ápice adpresso-pubescente a lanoso-pubescente, entrenós 20-140 mm compr. Estípulas persistentes, 4-6 × 2,5-5,5-6 mm, inteiras, ovadas a oblonga-ovadas, reflexas, ápice apiculado, externamente adpresso-pubescente internamente glabra. Folhas opostas, cartáceas, pecíolo 4-11 mm compr., lâmina 20-90 × 15-40 mm, elíptica a oblongo-lanceolada, base arredondada a truncada, ápice agudo a acuminado, margem plana; face adaxial hirsuta a esparso aracnoides, abaxial hirtelas ou esparso a denso seríceo; venação broquidódroma, nervuras secundárias proeminentes em ambas as faces, 10-14 pares. Inflorescências fascículos, axilares, 3-6-flores, pedúnculo 0,5-0,8 mm compr.; 3-4 brácteas, foliáceas ovadas, bractéolas ovadolanceoladas. Flores monoclinas, heterostílicas, sésseis; cálice 5 lobos iguais, 6-12 mm compr., linear-lanceolados, seríceo-pubescentes a hirsutos; corola hipocrateriforme, alva, tubo 11-14 mm compr., hirsuto externamente, pubescente com um anel de tricomas na inserção dos filetes, 5-mera, lobos 8-10 mm compr., oblongo a ovados, externamente hirsuto-barbados, internamente glabro; estames inseridos na porção mediana do tubo; anteras $2,5 \mathrm{~mm}$ compr., oblongas; estigma bífido; flores brevistilas, porção livre dos filetes 3-6 mm compr.; estilete 8-10 mm compr.; flores longistilas, estames sésseis; estiletes 12-16 mm compr. Fruto baga, 4-10 × 6-11 mm, globoso a subgloboso, vermelho na maturação, pubescente; sementes 2-3 mm compr., globosas, reticuladas.

Distribuição: Espécie endêmica do Brasil, ocorrendo na Bahia, Ceará, Goiás, Pará, Pernambuco, Rio de Janeiro, São Paulo e Tocantins (Delprete 2010c).

Caracteriza-se através do hábito lianescente pelas estípulas reflexas com indumento adpresso-pubescente, e frutos baçáceos globosos com polpa esponjosa. Foi encontrada associada às florestas de galeria e campo rupestre sobre solos argilosos, entre 460-780 m altitude. Floresce na área em dezembro janeiro e fevereiro e frutifica em março.

Material examinado: BRASIL. BAHIA: Pindobaçu, Serra da Fumaça. $10^{\circ} 39$ ' 59" S e 40²1' 59"' W, 19/XI/2011, fl., L.A. Sousa 481 (HUNEB); 26/XI/2011, fl., L.A. Sousa 496 (HUNEB)17/ III/2012, fl., L.A. Sousa 555 (HUNEB); 17/III/2012, fl., L.A. Sousa 556 (HUNEB) $10^{\circ} 39^{\prime} 57^{\prime \prime} \mathrm{S}$ e $40^{\circ} 22^{\prime} 14$ " W, 20/I/2012, fl., L.A. Sousa 511 (HUNEB); 20/I/2012, fl., L.A. Sousa 520 (HUNEB); 17/V/2012, fr., L.A. Sousa 567 (HUNEB).

34. Staelia vestita K. Schum., Fl. Bras. 6(6): 78. 1889.

Figura 8I-L

Erva ou subarbusto, eretos, 30-40 cm alt., monoica; caule cilíndrico a tetrágonos no ápice, sem lenticelas, tomentoso a viloso, entrenós 2,5-17 mm compr. Estípulas fimbriadas, persistentes, bainha
1-1,5 × 2-2,5 mm, pubérula, 4-6 setas desiguais, 1-2,5 mm compr., tomentosas próximo ao ápice. Folhas pseudoverticiladas devido aos braquiblastos nas axilas, cartáceas, sésseis; lâmina 6-14 × 1-2,5 mm, lanceolada, base atenuada, ápice agudo, margem plana; face adaxial glabra a escabra, abaxial glabra a tomentosa próximo das nervuras; venação eucamptódroma, nervuras secundárias inconspícuas em ambas as faces, 2 pares. Inflorescências em glomérulos, terminais e axilares, 8-13 por ramo florífero, multifloros; 2-3 brácteas, foliáceas, lanceoladas, bractéolas inconspícuas. Flores monoclinas, homostílicas, sésseis; cálice 2 lobos iguais, 2-2,2 mm compr., lanceolados, hirsutos; corola alva a lilás, infundibuliforme, tubo 2,2-3 mm compr., externamente viloso, internamente com anel de tricomas na porção inferior, 4-mera, lobos 2-2,2 mm compr., ovaltriangulares, externamente hirsutos; estames excertos, inseridos na fauce, porção livres dos filetes $0,8-1,2 \mathrm{~mm}$ compr., anteras $0,8-1 \mathrm{~mm}$ compr., oblongas; estigma bífido, estiletes 5-5,5 mm compr. Fruto cápsula, septicida, 3-3,8 × 1,2-1,8 mm, obovoide, deiscência longitudinal-oblíqua, valvas totalmente livres, decíduas, marromacinzentada na maturação, hirsuta; sementes $0,9-1,1 \times 0,5 \mathrm{~mm}$, semicirculares, castanhas, sulco longitudinal na face ventral.

Distribuição: Espécie endêmica do Brasil (Souza \& Sales 2004, Schumann 1888). Distribui-se nas regiões Nordeste (BA, PE, PI), Centro-Oeste (GO, MT, TO) (Delprete 2010c), nos domínios da Caatinga e Cerrado (Salas \& Cabral 2012).

Staelia vestita é próxima de $S$. virgata que também ocorrente na área, diferenciando-se através do indumento no caule (tomentosoviloso $v s$ caule glabro a pubérulo) e da lâmina foliar (face superior escabra vs glabra), e pelo comprimento da corola (4-4,5 vs 6,8-7,2 mm). Foi encontra na área associada a solos arenosos, no campo rupestre, a $890 \mathrm{~m}$ de altitude. Floresce e frutifica na área apenas no mês de novembro.

Material examinado: BRASIL. BAHIA: Pindobaçu, Serra da Fumaça. $10^{\circ} 39^{\prime} 54,6$ " $\mathrm{S}$ e $40^{\circ} 22^{\prime} 20^{\prime}$ ' W, 19/IX/2011, fl., fr., L.A. Sousa 486 (HUNEB).

Material adicional examinado: BRASIL. BAHIA: Caetité, Brejinho das Ametistas, 24/IV/2008, fl., fr., M.L. Guedes 14359 (ALCB); Mucugê, estrada para Igatu, 21/VII/2005, fl., A.K.A. Santos 274 (HUEFS); Mucugê, 3 km de Andaraí, 07/VII/2006, fl., S.A. Mori 13111 (CEPEC).

35. Staelia virgata (Roem. \& Schult.) K.Schum., Fl. Bras. 6(6): 76. 1889 .

Erva ou subarbusto, eretos, $40-70 \mathrm{~cm}$ alt., monoica; caule cilíndrico a tetrágonos no ápice, sem lenticelas, pubérulos, entrenós 09-28 mm compr. Estípulas fimbriadas, persistentes, bainha 1-1,8 $\times 1,8-2 \mathrm{~mm}$ compr., pubérula, 4-8 setas desiguais, 0,5-1,5 mm compr., glabras, coléteres no ápice. Folhas pseudoverticiladas devido aos braquiblastos nas axilas, cartáceas, sésseis; lâmina 5-15 × 3-4 mm, lanceolada, base atenuada, ápice agudo, margem plana; face adaxial glabra, abaxial pubérula apenas nas nervuras; venação eucamptódroma, nervuras secundárias proeminentes em ambas as faces, 2 pares. Inflorescências glomérulos, terminais e axilares, 3-8 por ramo florífero, multifloras; 2 brácteas, foliáceas, lanceoladas, bractéolas inconspícuas. Flores monoclinas, homostílicas, sésseis; cálice 2 lobos iguais, 2-3 mm compr., lanceolados, hirsutos; corola alva a lilás, infundibuliforme, tubo 4,8-5,2 mm compr., externamente glabro, internamente com anel de tricomas na porção inferior, 4-mera, lobos 1,5-2 mm compr., oval-triangulares, externamente hirsutos; estames inclusos, inseridos na fauce, porção livres do filetes 1,2-1,6 mm compr., anteras 0,8-1 mm compr., oblongas; estigma bífido, estiletes 5-8 mm compr. Fruto cápsula, septicida, 1-1,5 × 1-1,2 mm, obovoide, deiscência longitudinal, valvas totalmente livres, decíduas, marrom-acinzentada na maturação, hirsuta; sementes $0,9-1,1 \times 0,5 \mathrm{~mm}$, oblongas, castanhas, sulco longitudinal na face ventral. 
Rubiaceae na Serra da Fumaça, Bahia, Brasil

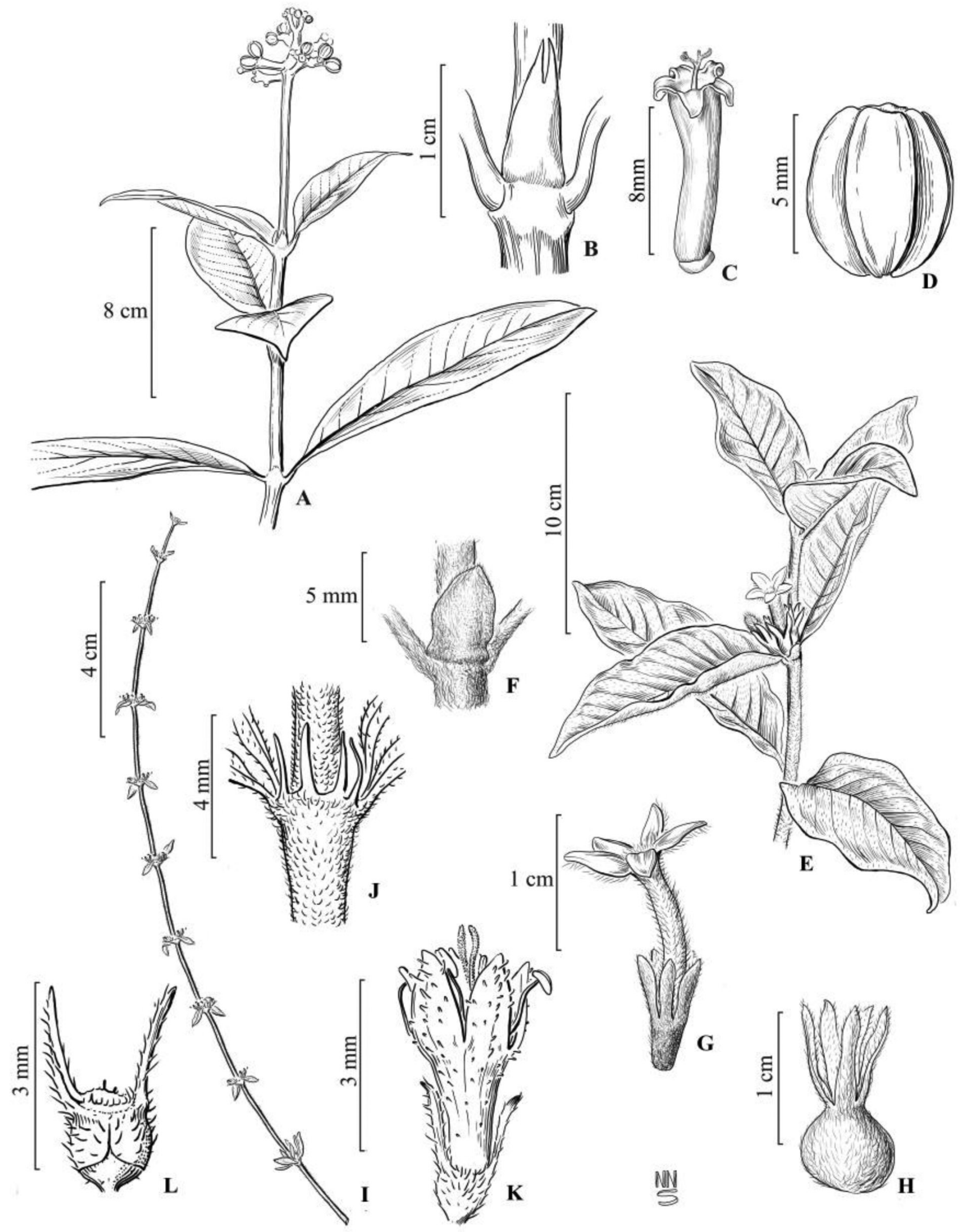

Figura 8. A-D. Psychotria jambosioides - A. ramo florífero; B. estípula; C. flor.; D. fruto. E-H. Sabicea grisea - E. ramo florífero; F. estípula; G. flor; H. fruto. I-K. Staelia vestita - I. ramo florífero; J. estípula; K. flor; L. fruto. (A-D. L.A. Sousa 334; E-H. L.A. Sousa 555; I-K. L.A. Sousa 501).

Figure 8. A-D. Psychotria jambosioides - A. flowering branch; B. stipule; C. flower; D. fruit. E-H. Sabicea grisea - E. flowering branch; F. stipule; G. Flower; H. fruit. I-K. Staelia vestita - I. flowering branch; J. stipule; K. flower; L. fruit. (A-D. L.A. Sousa 334; E-H. L.A. Sousa 555; I-K. L.A. Sousa 501). 
Distribuição: Está distribuída no Peru, Bolívia, Paraguai, Argentina e Brasil, (Andersson 1992). No Brasil, distribui-se em todas as regiões e em todos os domínios fitogeográficos (Salas \& Cabral 2012).

Caracteriza-se por apresentar lobos do cálice 2-4 mm compr., duas brácteas, folhas glabras e ramos florais pubescentes (Souza \& Sales 2004). Foi encontrada associada a áreas abertas de campo rupestre sobre solo areno-argiloso, entre 500 a $900 \mathrm{~m}$ de altitude. Floresce e frutifica na área em quase todos os meses do ano.

Material examinado: BRASIL. BAHIA: Pindobaçu, Serra da Fumaça, 10³9' 54" 'S e 40²0' 52" W, 28/VI/2011, fl., fr., L.A. Sousa 323 (HUNEB); 28/VI/2011, fl., fr., L.A. Sousa 324 (HUNEB); 26/ VIII/2011, fl., fl., L.A. Sousa 409 (HUNEB); $10^{\circ} 39^{\prime} 54,6^{\prime \prime} \mathrm{S}$ e $40^{\circ}$ 22' 20" W, 28/V/2008, fl., fr., L.A. Sousa 95 (HUNEB); 14/II/2009, fl., fr., L.A. Sousa 283 (HUNEB); 22/IV/2008, fl., fr., L.A. Sousa 58 (HUNEB); 26/VII/2011, fl., fr., L.A. Sousa 581 (HUNEB); 26/ VII/2011, fl., fr., L.A. Sousa 473 (HUNEB); 19/XI/2011, fl., fr., L.A. Sousa (HUNEB); $10^{\circ} 39$ ' 58,6" S e 40 31' 18" W, 20/I/2012, fl., fr., L.A. Sousa 511 (HUNEB); 26/XII/2011, fl., fr., L.A. Sousa 505 (HUNEB); 26/XII/2011, fl., fr., L.A. Sousa 506 (HUNEB).

36. Tocoyena formosa (Cham. \& Schltdl.) K. Schum., Fl. Bras. 6: 347.1889.

Arbusto, 2-2,5 m alt., monoico; caule cilíndrico, sem lenticelas, glabro a pubérulo no ápice, entrenós 20-80 mm compr. Estípulas persistentes, 3-5 $\times$ 4-5 $\mathrm{mm}$, inteiras, triangulares, ápice agudo, externamente glabras, internamente tomentosas no ápice. Folhas opostas, cartáceas a subcoriáceas, pecíolo 5-20 mm compr., velutino; lâmina 90-200 × 60-110 mm, obovada a elíptica, base cuneada, ápice agudo, margem plana; face adaxial pubescente, abaxial tomentosa; venação broquidódroma, nervuras proeminentes na face abaxial, 7-11 pares. Inflorescências corimbos, terminais, 4-7 flores, pedúnculo 8-11 mm compr., pubérulo; brácteas foliáceas e bractéola triangularlanceoladas. Flores monoclinas, homostílicas, sésseis; cálice 5 lobos, denteados, 0,8-1 mm compr., triangulares, tomentosos; corola amarela, hipocrateriforme, tubo 90-110 mm compr., externamente tomentoso, internamente glabro, 5-mera, lobos 18-20 mm compr., obovados, externamente tomentosos; estames exsertos, inseridos na fauce, porção livre 0,5-0,8 mm compr.; anteras 7-9 mm compr., elípticas; estigma bífido, estilete $90-130 \mathrm{~mm}$ compr. Fruto baga, 18-25 × 15-35 mm, globoso, negra na maturação, pubérula a híspida; sementes 4-5 × 3,8-5 mm, orbiculares, compressas, exotesta lisa.

Distribuição: Distribui-se amplamente na região neotropical (Andersson 1992). No Brasil, ocorre em todas as regiões e em quase todos os estados (Zappi 2012c).

Caracteriza-se por apresentar corola longamente tubulosa, amarela e frutos bacáceos, vilosos. Foi encontrada associada a áreas de Caatinga perturbada, sobre solo argiloso a $490 \mathrm{~m}$ de altitude. Floresce na área em janeiro, fevereiro e abril e frutifica em abril.

Material examinado: BRASIL. BAHIA: Pindobaçu, Serra da Fumaça. $10^{\circ} 39$ ' 25" S e 40²2' 25" W, 20/I/2012, fl., L.A. Sousa 539 (HUNEB); 20/II/2012, fl., L.A. Sousa 517 (HUNEB); 17/III/2012, fl., fr., L.A. Sousa 561, (HUNEB).

\section{Agradecimentos}

À Coordenação de Aperfeiçoamento de Pessoal de nível Superior - CAPES pela concessão da bolsa à primeira autora, a qual permitiu o desenvolvimento da pesquisa; aos curadores dos herbários ALCB, BAH, CEPEC, HRB e HUEFS pelo apoio durante as visitas; aos professores do PPGBVeg pelo auxílio direto ou indireto na construção do trabalho; ao Natanel Nascimento dos Santos, pelas ilustrações das espécies; e ao Gabriel Lima pela produção dos mapas da área de estudo. Á Marcela F. da Silveira e ao Roberto Salas pela significativa contribuição na revisão do manuscrito.

\section{Referências Bibliográficas}

ANDERSSON, L. 1992. A provisional checklist of Neotropical Rubiaceae. Scripta Bot. Belg. 1:1-199.

BACIGALUPO, N.M. \& CABRAL, E.L. 2007a. Borreria G.Mey., nom.cons. In Flora Fanerôgama do Estado de São Paulo (M.G.L. Wanderley, G.J. Shepherd, T.S.Melhem \& A.M. Giulietti, coords.). FAPESB/RIMA, São Paulo, v.5, p.276-285.

BACIGALUPO, N.M. \& CABRAL, E.L. 2007b. Diodella Small. In Flora Fanerôgama do Estado de São Paulo (M.G.L. Wanderley, G.J. Shepherd, T.S.Melhem \& A.M. Giulietti, coords.). FAPESB/RIMA, São Paulo, v. 5, p. 313-314.

BACIGALUPO, N.M. \& CABRAL, E.L. 2007c. Emmeorhiza Pohl. In Flora Fanerôgama do Estado de São Paulo (M.G.L. Wanderley, G.J. Shepherd, T.S.Melhem \& A.M. Giulietti, coords.). FAPESB/RIMA, São Paulo, v.5, p.318-319.

BARBOSA, M.R.V. 2012a. Guettarda. In Lista de Espécies da Flora do Brasil (Jardim Botânico do Rio de Janeiro). http://floradobrasil.jbrj.gov.br/2012/ FB020753 (último acesso em 02/07/2012).

BARBOSA, M.R.V. 2012b. Malanea. In Lista de Espécies da Flora do Brasil (Jardim Botânico do Rio de Janeiro). http://floradobrasil.jbrj.gov.br/2012/ FB020770 (último acesso em 02/07/2012).

BARBOSA, M.R.V. 2012c. Posoqueria. In Lista de Espécies da Flora do Brasil (Jardim Botânico do Rio de Janeiro). http://floradobrasil.jbrj.gov. br/2012/FB014150 (último acesso em 04/06/2012).

BARBOSA, M.R.V. \& ZAPPI, D. 2002. Distribuição das espécies de Rubiaceae na Caatinga. In Vegetação e Flora da Caatinga (E.V.S.B. Sampaio, A.M. Giuliette, J. Virginio, C.F.L. Gamarra-Rojas, eds.). APNE/ CNIP, p.155-157.

BARBOSA, M.R.V., ZAPPI, D., TAYLOR, C., CABRAL, E., JARDIM, J.G., PEREIRA, M.S., CALIÓ, M.F., PESSOA, M.C.R., SALAS, R., SOUZA, E.B., DI MAIO, F.R., MACIAS, L., ANUNCIAÇÃO, E.A. DA, GERMANO FILHO, P., OLIVEIRA, J.A. \& BRUNIERA, C.P. 2012. Rubiaceae. In Lista de Espécies da Flora do Brasil (Jardim Botânico do Rio de Janeiro). http://floradobrasil.jbrj.gov.br/2012/FB000210 (último acesso em 26/12/2012).

BRUMMITT, R.K. \& POWELL, C.E. 1992. Authors of plant names. Royal Botanic Gardens, Kew.

BURGER, W. \& TAYLOR, C.M. 1993. Family 202 Rubiaceae. In Flora costaricensis (W. Burger, ed.). Fieldiana, Bot. n.s. 33, p.1-333.

CABRAL, E.L. \& BACIGALUPO, N.M. 1999. Estudio de las especies americanas de Borreria series Leaves (Rubiaceae, Spermacoceae). Darwiniana 37(3-4):259-277.

CABRAL, E.L. \& BACIGALUPO, N.M. 2005. Novelties in Spermacoceae (Rubiaceae) from Bolivia and Paraguay. Brittonia 57(2):129-140. http:// dx.doi.org/10.1663/0007-196X(2005)057[0129:NISRFB]2.0.CO;2

CABRAL, E.L., MIGUEL, L.M. \& SALAS, R.M. 2011. Dos especies nuevas de Borreria (Rubiaceae), sinopsis y clave de las especies para Bahia, Brasil. Acta Bot. Bras. 25(2):255-276. http://dx.doi.org/10.1590/S010233062011000200002

CABRAL, E. \& SALAS, R. 2012a. Borreria. In Lista de Espécies da Flora do Brasil (Jardim Botânico do Rio de Janeiro). http://floradobrasil.jbrj. gov.br/2012/FB020694 (último acesso em 02/07/2012).

CABRAL, E. \& SALAS, R. 2012b. Diodella. In Lista de Espécies da Flora do Brasil (Jardim Botânico do Rio de Janeiro). http://floradobrasil.jbrj. gov.br/2012/FB013934 (último acesso17/06/2012).

CABRAL, E. \& SALAS, R. 2012c. Emmeorhiza. In Lista de Espécies da Flora do Brasil (Jardim Botânico do Rio de Janeiro). http://floradobrasil.jbrj. gov.br/2012/FB013938 (último acesso em 02/07/2012).

CABRAL, E. \& SALAS, R. 2012d. Richardia. In Lista de Espécies da Flora do Brasil. Jardim Botânico do Rio de Janeiro. http://floradobrasil.jbrj. gov.br/2012/FB014235 (último acesso em 03/06/2012). 
CAMPOS, M.T.V.A., ZAPPI, D.C., CALIÓ, M.F. \& PIRANI, J.R. 2006 Flora de Grão-Mogol: Rubiaceae. Bol. Bot. Univ. São Paulo 24:41-67.

CHAW, S.M. \& PENG, C.I. 1987. Remarks on the species of Spermacoceae (Rubiaceae) of Taiwan. J. Taiwan Mus. 40:71-83.

COSTA, C.B. 2004. Revisão taxonômica de Coccocypselum P.Br. (Rubiaceae). Tese de Doutorado, Universidade de São Paulo.

CostA, C.B. \& MAMEDE, M.C.H. 2002. Sinopse do Gênero Coccocypselum P. Browne (Rubiaceae) no Estado de São Paulo, Brasil. Biota Neotropica 2(1)-http://www.biotaneotropica.org.br/v2n1/pt/ abstract?article+BN01402012002 (último acesso em 03/09/2012).

COMPANHIA DE PESQUISA DE RECURSOS MINERAIS - CPRM. 2005. Serviço Geológico do Brasil: Projeto Cadastro de Fontes de Abastecimento por Água Subterrânea: Diagnóstico do Município de Pindobaçu. CPRM/ PRODEEM, Salvador.

DELPRETE, P.G. 2010a. Rubiaceae - Parte 1: Introdução, gêneros A - H. In Flora dos Estados de Goiás e Tocantins: coleção Rizzo (J.A. Rizzo, coord.). PRPPG/UFG e IRD, Goiânia, v.40, parte 1.

DELPRETE, P.G. 2010b. Rubiaceae - Parte 2: gêneros I - R. In Flora dos Estados de Goiás e Tocantins: coleção Rizzo (J.A. Rizzo, coord.). PRPPG/ UFG e IRD, Goiânia, v.40, parte 2.

DELPRETE, P.G. 2010c. Rubiaceae - Parte 3: gêneros S - W. In Flora dos Estados de Goiás e Tocantins: coleção Rizzo (J.A. Rizzo, coord.). PRPPG/ UFG e IRD, Goiânia, v.40, parte 3.

DELPRETE, P.G. \& CORTÉS-B, R. 2006. A synopsis of the Rubiaceae of the states of Mato Grosso and Mato Grosso do Sul, Brazil, with a key to genera, and a preliminary species list. Rev. Biol. Neotrop. 3:13-96.

DELPRETE, P.G. \& JARDIM, J.G. 2012. Systematics, taxonomy and floristics of Brazilian Rubiaceae: an overview about the current status and future challenges. Rodriguésia 63(1):101-128. http://dx.doi.org/10.1590/S217578602012000100009

DELPRETE, P.G., SMITH, L.B. \& KLEIN, R.M. 2004. Rubiáceas: I parte - As plantas/monografia - Rubi. In Flora Ilustrada Catarinense (A. Reis, ed.). Herbário ‘Barbosa Rodrigues', Itajaí, v.1 gêneros de H-T.

DELPRETE, P.G., SMITH, L.B. \& KLEIN, R.M. 2005. Rubiáceas: I parte - As plantas / monografia - Rubi. In Flora Ilustrada Catarinense (A. Reis, ed.). Herbário 'Barbosa Rodrigues', Itajaí, v.2 gêneros de de A-G.

DIMITRI, S.B. 1959. Rubiaceae da cidade do Rio de Janeiro: tribo Spermacoceae. Rodriguésia 22(33/34):241-283.

DWYER, J.D. 1980. Flora of Panamá. 179. Rubiaceae. Ann. Missouri Bot. Gard. 67(1):1-256.

GERMANO FILHO, P. 1999. Estudos Taxonômicos do gênero Bathysa C. Presl (Rubiaceae, Rondeletieae), no Brasil. Rodriguésia 50(76-77):49-75.

GIULIETTI, A.M. \& PIRANI, J.R. 1988. Patterns of geographic distribution of some plant species from the Espinhaço Range, Minas Gerais and Bahia, Brazil. In (W.R. Heyer \& P.E. Vanzolini, eds.). Proceedings of a workshop on Neotropical Distribution Patterns. Anais Acad. Brasil. Ci. 60:39-69.

GIULIETTI, A.M., PIRANI, J.R. \& HARLEY, R.M. 1997. Espinhaço Range Region, Eastern Brazil. In Centres of plant diversity. A guide and strategy for their conservation. (S.D. Davis, V.H. Heywood, O Herrera-Macbryde, J. Villa-Lobos \& A.C Hamilton, eds.). IUCN Publication, Cambridge, v.3. The Americas, p.397-404.

GIULIETTI, A.M., QUEIROZ, L.P. \& RAPINI, A, eds. 2006. Towards greater knowledge of the Brazilian. Biodiversity and conservation of plants in Brazilian semi-arid biodiversity. Programa de Pesquisa em Biodiversidade (PPBio), Ministério da Ciência e Tecnologia.

GOVAERTS, R., ANDERSSON, L., ROBBRECHT, E., BRIDSON, D., DAVIS, A., SCHANZER, I. \& SONKE, B. 2012. World Checklist of Rubiaceae. Facilitated by the Royal Botanic Gardens. http://www.kew. org/science-research-data/directory/teams/rubiaceae/index.htm (último acesso em 20/abr/2012).

HARLEY, R.M. 1995. Introduction. In Flora of the Pico das Almas, Chapada Diamantina (B.L. Stannard, ed.). Brazil. Royal Botanic Gardens, Kew, p.1-42.
HARLEY, R.M., GIULIETTTI, A.M., GRILO, A.S., SILVA, T.R.S., FUNCH, L., FUNCH, R.R., QUEIROZ, L.P., FRANÇA, F., MELO, E., .GONÇALVES, C.N. \& NASCIMENTO, F.H.F. 2005. Cerrado. In Biodiversidade e conservação da Chapada Diamantina (F.A. Junca, L. Funch \& R. Rocha, orgs.). Ministério do Meio Ambiente, Brasília, p.121-152.

HARRIS, J.G. \& HARRIS, M.W. 2001. Plant identification terminology: an illustrated glossary. 2nd ed. Spring Lake Publishing, Spring Lake, 206p.

JARDIM, J.G. \& ZAPPI, D.C. 2008a. Two New Species of Faramea (Rubiaceae, Coussareeae) from Eastern Brazil. Novon 18:67-71. http:// dx.doi.org/10.3417/2006182

JARDIM, J.G. \& ZAPPI, D.C. 2008b. Studies of Faramea Aubl. (Rubiaceae) in Brazil: two new species for Eastern Bahia - F. nocturna and F. biflora. Kew Bull. 63:131-136. http://dx.doi.org/10.1007/s12225-007-9011-9

JARDIM, J.G. \& ZAPPI, D.C. 2008c. Carapichea lucida (Rubiaceae: Psychotrieae), a new species from Eastern Bahia, Brazil. Kew Bull. 63:661-664. http://dx.doi.org/10.1007/s12225-008-9075-1

JUNG-MENDAÇOLLI, S.L. 2007. Rubiaceae. In Flora Fanerôgama do Estado de São Paulo (M.G.L. Wanderley, G.J. Shepherd, T.S.Melhem \& A.M. Giulietti, coords.). FAPESB/RIMA, São Paulo, v.5, p.259-447.

KIRKBRIDE JUNIOR, J.H. 1976. A revision of the genus Declieuxia (Rubiaceae). Mem. New York Bot. Gard. 28(4):1-87.

LEAF ARCHITECTURE WORKING GROUP - LAWG. 1999. Manual of leaf architecture - morphological description and categorization of dicotyledonous and net-veined monocotyledonous angiosperms by leaf architecture. Smithsonian Institution, Washington.

LEWIS, W. H. \& OLIVER. R. L. 1974. Revision of Richardia (Rubiaceae). Brittonia 26(3):271-301. http://dx.doi.org/10.2307/2805730

MACIAS, L.F.N. 1988. Revisão Taxonômica do gênero Posoqueria Aubl. (Rubiaceae). Dissertação de Mestrado, Universidade Estadual de Campinas, Campinas.

MALDONADO, C. 2005. Las Rubiáceas encontradas en el proyecto de Inventario Botánico de la región de Madidi. Ecol. Bolivia 40(3):199-211.

MASCARENHAS, J.F., LEDRU, P., SOUZA, S.L., CONCEIÇÃO FILHO, V.M., MELO, L.F.A., LORENZO, C.L. \& MILÉSI, J.P. 1998. Geologia e recursos minerais do Grupo Jacobina e da parte sul do Greenstone Belt de Mundo Novo. Companhia Baiana de Pesquisa Mineral, Salvador. Série Arquivos Abertos.

MELO, A.S. \& BARBOSA, M.R.V. 2007. O gênero Borreria G. Mey (Rubiaceae) na Mata do Buraquinho, João Pessoa, Paraíba. Rev. Bras. Bioci. 5(2):627-629.

MILESI, J.P.; LEDRU, P., MARCOUX, E., MOUGEOT, R., JOHAN, V., LEROUGE, C.; SABATE, P., BAILly, L., RESPAUT, J.P. \& SKIPWITH, P. 2002. The Jacobina Paleoproterozoic gold-bearing conglomerates, Bahia, Brazil: a hydrothermal shear-reservoir model. Ore Geo. Rev. 19:95-136. http://dx.doi.org/10.1016/S0169-1368(01)00038-5

MORI, S.A.; SILVA, L.A.M.; LISBOA, G. \& CORADIN, L. 1989. Manual de manejo do herbário fanerogâmico. CEPLAC, Ilhéus.

MÜLLER, A. J. 1881. Rubiaceae. In Flora brasiliensis (C.F.P. Martius, ed.). F. Fleischer, Lipsiae, v.6 pars 5, p.1-470.

PEREIRA, M.S. \& BARBOSA, M.R.V. 2004. A família Rubiaceae na Reserva Biológica Guaribas, Paraíba, Brasil. Subfamílias Antirheoideae, Cinchonoideae e Ixoroideae. Acta Bot. Bras. 18(2):305-318. http://dx.doi. org/10.1590/S0102-33062004000200010

PEREIRA, M.S. \& BARBOSA, M.R.V. 2006. A família Rubiaceae na Reserva Biológica Guaribas, Paraíba, Brasil. Subfamília Rubioideae. Acta Bot. Bras. 20(2):455-470. http://dx.doi.org/10.1590/S010233062006000200021

PESSOA, M.C.R. \& MACIAS, L. 2012. Manettia. In Lista de Espécies da Flora do Brasil (Jardim Botânico do Rio de Janeiro). http://floradobrasil. jbrj.gov.br/2012/FB014098 (último acesso em 02/08/2012).

PESSOA, M.C.R. \& ZAPPI, D. 2012. Cordiera. In Lista de Espécies da Flora do Brasil (Jardim Botânico do Rio de Janeiro). http://floradobrasil.jbrj. gov.br/2012/FB038701 (último acesso em 02/08/2012). 
PRADO, A.L. 1987. Revisão taxonômica do gênero Tocoyena Aubl. (Rubiaceae) no Brasil. Dissertação de Mestrado, Universidade Estadual de Campinas, Campinas.

RADFORD, A.E., DICKISON, W.C., MASSEY, J.R. \& BELL, C.R. 1974. Vascular Plant Systematics. Harper \& Row Publ., New York.

ROBBRECHT, E. 1988. Tropical woody Rubiaceae. Opera Bot. Belg. 1:1-271.

SALAS, R. \& CABRAL, E. 2012. Staelia. In Lista de Espécies da Flora do Brasil (Jardim Botânico do Rio de Janeiro). http://floradobrasil.jbrj.gov. br/2012/FB014329 (último acesso em 17/06/2012).

SANTANA, A.J., MOREIRA, M.D. \& COUTO, P.A.A. 1995. Esmeralda de Carnaíba e Socotó, Bahia: Geologia e Potencialidade Econômica. In Série Arquivos Abertos, CBPM (Companhia Baiana de Pesquisa Mineral), v.26, 26 p.

SCHUMANN, K. 1888. Rubiaceae. In Flora brasiliensis (C.F.P. Martius, ed.). F. Fleischer, Lipsiae, v.6, pars 6, p.1-123.

SOUZA, E.B. 2012. Mitracarpus. In Lista de Espécies da Flora do Brasil (Jardim Botânico do Rio de Janeiro). http://floradobrasil.jbrj.gov.br/2012/ FB038964 (último acesso em 20/08/2012).

SOUZA, E.B., CABRAL, E.L. \& ZAPPI, D.C. 2010. Revisão de Mitracarpus (Rubiaceae - Spermacoceae) para o Brasil. Rodriguésia 61:319-352.

SOUZA, E.B. \& SALES, M.F. 2004. O gênero Staelia Cham. \& Schltdl. (Rubiaceae - Spermacoceae) no Estado de Pernambuco, Brasil. Acta Bot. Bras. 18(4):919-926. http://dx.doi.org/10.1590/S010233062004000400023

STEYERMARK, J.A. 1967. Rubiaceae. In Botany of the Guayana Highlands, Part VII (B. Maguire \& J.J. Wurdack, eds.). Mem. New York Bot. Gard. 17(1):230-436.

STEYERMARK, J.A. 1972. Rubiaceae. In Botany of the Guayana Highlands. Part IX. (B. Maguire \& J.J. Wurdak) Mem. New York Bot. Gard. 23:227832.

STEYERMARK, J.A. 1974. Rubiaceae. In Flora de Venezuela (T. Lasser, ed.). Instituto Botánico, Caracas, v.9, n.1, p.478-494.

TAYLOR, C. 2012. Psychotria. In Lista de Espécies da Flora do Brasil (Jardim Botânico do Rio de Janeiro). http://floradobrasil.jbrj.gov.br/2012/ FB014185 (último acesso em 02/07/2012).

TAYLOR, C. 2007. Psychotria L. nom.cons. In Flora Fanerôgama do Estado de São Paulo (M.G.L. Wanderley, G.J. Shepherd, T.S.Melhem \& A.M. Giulietti, coords.). FAPESB/RIMA, São Paulo, v.5, p.389-412.
TAYLOR, C.M., CAMPOS, M.T.V. \& ZAPPI, D. 2007. Flora da Reserva Ducke, Amazonas, Brasil: Rubiaceae. Rodriguésia 58:549-616.

TAYLOR, C.M., STEYERMARK, J.A., DELPRETE, P.G., VICENTINI, A., CORTÉS, R., ZAPPI, D., PERSSON, C., COSTA, C.B. \& ANUNCIAÇÃO, E.A. 2004. Rubiaceae. In Flora of the Venezuelan Guyana (J.A. Steyermark, et al. eds.). Mem. New York Bot. Gard. 8:497874.

THIERS, B. 2012. Index Herbariorum: a global directory of public herbaria and associated staff. New York Botanical Garden's Virtual Herbarium. http://sweetgum.nybg.org/ih. (último acesso em 02/12/2012).

VALE, M.S.F. 2005. Análise da recepção dos moradores da Serra de Jacobina em relação ao desenvolvimento do ecoturismo associado a educação ambiental. Dissertação de mestrado, Universidade Federal da Bahia, Salvador.

ZAPPI, D.C. 1998. Rubiaceae. In Check-list das espécies vasculares de Morro do pai Inácio (Palmeiras) e Serra da Chapadinha (Lençóis), Chapada Diamantina, Bahia, Brasil. (M.L. Guedes, org.). Instituto de Biologia da UFBA, Salvador, 79p.

ZAPPI, D. 2008. Fitofisionomia da Caatinga associada à Cadeia do Espinhaço. Megadiversidade 4(1-2):34-37.

ZAPPI, D. 2012a. Coutarea. In Lista de Espécies da Flora do Brasil (Jardim Botânico do Rio de Janeiro). http://floradobrasil.jbrj.gov.br/2012/ FB013915 (último acesso em 02/07/2012).

ZAPPI, D. 2012b. Perama. In Lista de Espécies da Flora do Brasil (Jardim Botânico do Rio de Janeiro). http://floradobrasil.jbrj.gov.br/2012/ FB020801 (último acesso 01/07/2012).

ZAPPI, D. 2012c. Tocoyena. In Lista de Espécies da Flora do Brasil (Jardim Botânico do Rio de Janeiro). http://floradobrasil.jbrj.gov.br/2012/ FB014338 (último acesso em 28/07/2012).

ZAPPI, D.C., LUCAS, E., STANNARD, B.L., LUGHADHA, E., PIRANI, J.R., QUEIROZ, L.P., ATKINS, S., HIND, N., GIULIETTI, A.M., HARLEY, R.M., MAYO S.J. \& CARVALHO. A.M. 2003. Lista de plantas vasculares de Catolés, Chapada Diamantina, Bahia, Brasil. Bol. Bot. Univ. São Paulo 21:345-398.

ZAPPI, D.C. \& STANNARD, B. 1995. Rubiaceae. In Flora of the Pico das Almas (B.L. Stannard, ed.). p.546-578.

ZAPPI, D. \& TAYLOR, C. 2012. Palicourea. In Lista de Espécies da Flora do Brasil (Jardim Botânico do Rio de Janeiro). http://floradobrasil.jbrj. gov.br/2012/FB014138 (último acesso em 02/07/2012).

Recebido em 22/02/2013

Versão reformulada recebida em 01/08/2013

Publicado em 19/08/2013 